\title{
Compilación y análisis de las investigaciones científicas sobre temas marinos y atmosféricos en el Pacífico Norte de Costa Rica
}

\author{
Jorge Cortés ${ }^{1,2}$ \\ 1. Centro de Investigación en Ciencias del Mar y Limnología (CIMAR), Ciudad de la Investigación, Universidad de \\ Costa Rica, San Pedro, 11501-2060 San José, Costa Rica; jorge.cortes@ucr.ac.cr \\ 2. Escuela de Biología, Universidad de Costa Rica, San Pedro, 11501-2060 San José, Costa Rica
}

Recibido 11-III-2014. Corregido 19-VIII-2014. Aceptado 27-IX-2014.

\begin{abstract}
Compilation and analysis of marine and atmospheric research from the North Pacific of Costa Rica. The North Pacific coast of Costa Rica extends from Bahía Salinas, bordering with Nicaragua on the north to Islas Negritos in the Golfo de Nicoya on the south This region is biologically rich and economically very important for the country. The far north of this region experiences a seasonal upwelling, related to the increase in the Trade Winds (from December to April-May). As a result of the upwelling water temperature decreases while nutrients concentrations and $\mathrm{CO}_{2}$ in the surface waters increase. These oceanographic changes have important consequences for the marine organisms, for example the seasonal growth of macroalgae. This paper aims to compile all the publications available on marine and atmospheric research on the North Pacific of Costa Rica. A total of 587 documents were located and analysed. Most of the publications are on biodiversity, followed by ecological studies, and there are few publications on other topics. Mangroves are the coastal ecosystem, with most papers, followed by coral reefs. Of other coastal ecosystems there are few publications if at all. The best studied groups are the marine turtles, decapod crustaceans and gastropods, followed by bivalves and fishes. By far the most studied area is Bahía Culebra, followed by Bahía Santa Elena. Most of the publications are scientific papers in journal with 487 . There is also an important number of thesis, 36. The number of publications and the diversity of topics for the North Pacific is relatively high, but more studies are needed in other geographic areas and topics, and monitoring should be reinforced and extended. The North Pacific of Costa Rica is a region that is changing rapidly and we must have the scientific information to manage the marine environments in a sustainable way. Rev. Biol. Trop. 62 (Suppl. 4): 151-184. Epub 2014 Diciembre 01.
\end{abstract}

Key words: bibliography, Costa Rica, Pacific coast, marine science, meteorology.

El Pacífico Norte de Costa Rica, Centroamérica, se extiende desde Bahía Salinas en la frontera con Nicaragua en el norte, hasta las Islas Negritos en la parte externa del Golfo de Nicoya en el sur. Abarca la provincia de Guanacaste en su totalidad y parte de la provincia de Puntarenas. Es una región muy rica en organismos y ambientes marinos (Beebe, 1942; Cortés \& Wehrtmann, 2009; Cortés, Vargas-Castillo \& Nivia-Ruiz, 2012) y donde además hay una gran presión por turismo y pesca (IbarraGene, 1996; Jiménez, 1997; Jiménez, 2001b; Sánchez-Noguera, 2012a; Sánchez-Noguera, 2012b). En esta región se da el fenómeno de afloramiento estacional (Jiménez, 2001a; Amador, Alfaro, Lizano \& Magaña, 2006; Alfaro, Cortés, Alvarado, Jiménez, León, SánchezNoguera, Nivia-Ruiz \& Ruiz-Campos, 2012). Dicho afloramiento en el extremo norte la región la hace diferente al resto del país. De diciembre a abril-mayo, cuando soplan los Vientos Alisios a través del istmo, las aguas cálidas superficiales son desplazadas mar afuera y, como consecuencia, surgen aguas profundas que son frías, ricas en nutrientes, con bajas concentraciones oxígeno pero altas en dióxido de carbono (Alfaro et al., 2012; Rixen, Jiménez \& Cortés, 2012). Es una región con 
una diversidad de organismos marinos relativamente alta (Cortés et al., 2012), con manglares (Soto \& Jiménez, 1982; Zamora-Trejos \& Cortés, 2009), arrecifes coralinos (Glynn, Druffel \& Dunbar, 1983; Cortés \& Murillo, 1985; Cortés \& Jiménez, 2003; Jiménez, Cortés, León \& Ruiz, 2010) y zonas rocosas de entremarea (Madrigal-Castro, Cabrera-Peña, Monge-Esquivel \& Pérez-Acuña, 1984; Sibaja-Cordero \& Cortés, 2008; Sibaja-Cordero, Camacho-García \& Vargas-Castillo, 2014).

Bahía Culebra es de las zonas en el Pacífico Norte más ricas en especies y ambientes marinos, además de paisajes. Esta bahía también es una de las zonas bajo más presión humana. Recientemente se publicó una serie de trabajos sobre Bahía Culebra (Cortés, 2012a) donde se tratan éste y otros temas. Gonzalo Fernández de Oviedo y Valdes en su obra "Historia general y natural de las Indias, Libro X", describó parte de la costa Pacífica de Costa Rica, incluyendo el primer organimos marino, la serpiente de mar, Pelamis platurus de Bahía Culebra (Cortés, 2012b). Varios siglos después, Augener (1922) describió un poliqueto recolectado en Bahía Culebra por Anders Sandoe Oersted a mediados del Siglo XIX. En la década de 1930, tres expediciones importantes tomaron muestras de organismos marinos en el Pacífico Norte (Cortés 2012b). La Expedición Templeton Crocker de la Academia Nacional de Ciencias de California del $1^{\text {ro }}$ al 4 de julio de 1932 a bordo del Zaca (Crocker, 1933). Las expediciones de la Fundación Allan Hancock a bordo del Velero III en 1933, 1934, 1935 y 1939 recolectaron ampliamente en las bahías de Salinas, Santa Elena y Culebra, entre otras localidades (Fraser, 1943a, Fraser, 1943b). Finalmente, en 1938, de nuevo estuvo el Zaca en Costa Rica, esta vez bajo el mando de William Beebe; muestrearon en las bahías de Santa Elena, Isla Murciélago y Bahía Culebra, entre otras localidades (Beebe, 1938). Producto de esta expediciones se publica un número importante de trabajos sobre organismos marinos del Pacífico de Costa Rica (ver Lista de publicaciones abajo).
La información científica es fundamental para proteger, conservar y gestionar en forma sotenible los ecosistemas. Por un lado, la zona norte del país está siendo alterada muy rápidamente, afectando ecosistemas, organismos y ambientes, y por otro lado, todavía falta mucha información básica para entender el valor presente y futuro de esos ecosistemas y organismos marinos.

En este trabajo recopilo publicaciones científicas sobre organismos, ambientes, procesos y fenómenos marinos y atmosféricos o relacionados con actividades marinas en el Pacífico Norte. El objetivo es poner a disposición la lista de todo lo publicado, resaltar las áreas de investigación más prominentes y los vacíos de conocimiento con la finalidad de orientar investigaciones futuras.

\section{MATERIALES Y MÉTODOS}

Todas las publicaciones (revistas científicas, capítulos de libros, libros) y tesis sobre organismos, ambientes, procesos y fenómenos marinos y atmosféricos realizados en el Pacífico Norte de Costa Rica fueron compiladas de gran diversidad de fuentes y bases de datos, incluyendo los de este Suplemento del Pacífico Norte (Cortés \& Morales-Ramírez, 2014). Algunos de esos trabajos fueron realizados en su totalidad en la región de interés, mientras que otros cubren áreas geográficas más amplias dentro del país o del Pacífico Tropical Oriental, pero todos contienen alguna información del Pacífico Norte. Además, hago una clasificación de todos los documentos para determinar las frecuencias de diferentes tipos de investigaciones, los grupos de organismos más estudiados, como también un análisis de la distribución geográfica de donde se realizaron las investigaciones.

\section{RESULTADOS}

En total he ubicado 587 publicaciones (ver Lista de Publicaciones) de las cuales la gran mayoría son estudios biológicos. Muchos 
de los trabajos del Pacífico Norte son sobre la presencia de especies de organismos marinos con 282 trabajos sobre biodiversidad marina, seguido por estudios ecológicos (177 documentos). Otras áreas del conocimiento son oceanografía física (36 publicaciones), ciencias atmosféricas (30), biogeografía (23), pesquería (16), oceanografía química y contaminación (15) y bioerosión (11) (Cuadro 1).

Los ecosistemas marino-costeros de los que hay más publicaciones son los manglares con 26 documentos y los arrecifes coralinos

CUADRO 1

Número de publicaciones por tema

TABLE 1

Number of publications by topic

\begin{tabular}{|c|c|c|c|c|c|}
\hline Tema & \# Publ. & Tema & \# Publ. & Tema & \# Publ. \\
\hline $\mathrm{Af}=$ Afloramiento (= surgencia $)$ & 9 & $\mathrm{CtR}=$ Cotaminación, Radionucléidos & 2 & MoG = Gasterópodos, Mollusca & 60 \\
\hline $\mathrm{Al}=\mathrm{Algas}$ & 18 & CtS $=$ Desechos sólidos & 1 & $\mathrm{MoP}=$ Quitones, Mollusca & 5 \\
\hline AMP = Área Marina Protegida & 4 & $\mathrm{CV}=$ Conservación & 28 & $\mathrm{Ne}=$ Nemátodos & 1 \\
\hline $\mathrm{Ap}=$ Apendicularias & 2 & Di $=$ Dinoflagelados & 2 & $\mathrm{OF}=$ Oceanografía Física & 36 \\
\hline $\mathrm{Ar}=$ Arrecifes & 16 & $\mathrm{Ec}=$ Echinodermata & 4 & $\mathrm{OQ}=$ Oceanografía Química & 5 \\
\hline Arb $=$ Arribada & 19 & EcE $=$ Equinoideos, Echinodermata & 7 & Pc = Picnogónido & 1 \\
\hline At $=$ Actinomycetes & 1 & $\mathrm{EcH}=$ Holoturoideos, Echinodermata & 4 & $\mathrm{Pe}=$ Pesquería & 16 \\
\hline$A v=$ Aves & 4 & $\mathrm{EcO}=$ Ofiuroideos, Echinodermata & 2 & PEH = Pequeña Edad de Hielo & 1 \\
\hline $\mathrm{Bd}=$ Biodiversidad & 282 & $\mathrm{Eg}=$ Ecología & 177 & PiA = Peces óseos & 27 \\
\hline $\mathrm{Bg}=$ Biogeografía & 23 & En $=$ Enfermedades animales & 9 & $\mathrm{PiE}=$ Peces cartilaginosos & 8 \\
\hline $\mathrm{Bi}=$ Bioerosión & 11 & ENOS = El Niño-Oscilación del Sur & 4 & PiP $=$ Picoplancton & 1 \\
\hline Bin $=$ Bioindicadores & 2 & Ep $=$ Expediciones & 5 & Ply = Playas & 1 \\
\hline $\mathrm{Br}=$ Briozoarios & 6 & $\mathrm{Er}=$ Erosión costera & 1 & $\mathrm{PlZ}=$ Zooplancton & 8 \\
\hline $\mathrm{CA}=$ Ciencias Atmosféricas & 30 & FAN = Floración algal nociva & 3 & $\mathrm{PM}=$ Pastos Marinos & 1 \\
\hline $\mathrm{CC}=$ Cambio climático & 1 & $\mathrm{Fi}=$ Filogenias & 1 & PMM = Parásitos mamíferos marinos & 1 \\
\hline $\mathrm{Ci}=$ Cianobacterias & 2 & $\mathrm{Fg}=$ Filogeografia & 4 & Pol = Palinología & 1 \\
\hline $\mathrm{Cm}=$ Comportamiento & 4 & Fo $=$ Foraminíferos & 9 & $\mathrm{PP}=$ Productividad Primaria & 1 \\
\hline $\mathrm{Cn}=$ Cnidaria & 1 & Fs = Fisiología & 1 & PpA = Parásitos peces, Acantocéfalos & 4 \\
\hline $\mathrm{CnA}=$ Antozoarios, Cnidaria & 27 & Gn = Genética & 11 & $\mathrm{PpC}=$ Parásitos peces, Copépodos & 1 \\
\hline $\mathrm{CnH}=$ Hydrozoarios, Cnidaria & 10 & Go = Geomorfología & 1 & PpN = Parásitos peces, Nemátodos & 1 \\
\hline $\mathrm{CnM}=$ Medusas, Cnidaria & 4 & $\mathrm{Hi}=$ Historia & 7 & $\mathrm{PpP}=$ Parásitos peces, Platyhelmintos & 5 \\
\hline $\mathrm{Cr}=$ Crustacea & 3 & $\mathrm{Hu}=$ Humedales & 2 & PTB $=$ Parásitos Tortugas Bacterias & 1 \\
\hline $\mathrm{CrA}=$ Anfípodos, Crustacea & 6 & $\mathrm{IMa}=$ Insectos Marinos & 1 & PTP $=$ Parásitos Tortugas Platyhelmintos & 1 \\
\hline $\mathrm{CrC}=$ Copépodos, Crustacea & 3 & I $p=$ Ictioplancton & 1 & Py $=$ Poliquetos & 13 \\
\hline $\mathrm{CrD}=$ Decápodos, Crustacea & 68 & Is $=$ Imposexo & 1 & $\mathrm{Rp}=$ Reptiles & 11 \\
\hline $\mathrm{CrE}=$ Eufausidos, Crustacea & 1 & Ist $=$ Isótopos estables & 3 & $\mathrm{Sd}=$ Sedimentos & 4 \\
\hline $\mathrm{CrI}=$ Isópodos, Crustacea & 3 & $\mathrm{Lg}=$ Legislación & 3 & $\mathrm{SE}=$ Estudios socio-económicos & 5 \\
\hline $\mathrm{CrMi}=$ Misidáceos, Crustacea & 1 & LN = La Niña & 1 & $\mathrm{Si}=$ Sipuncúlidos & 5 \\
\hline $\mathrm{CrP}=$ Cirripedios, Crustacea & 4 & Ma = Manejo/gestión & 9 & Sy $=$ Simbiosis & 5 \\
\hline CrQ = Cumáceos, Crustacea & 2 & MdM = Mamíferos de Manglar & 1 & $\mathrm{TM}=$ Tortugas Marinas & 93 \\
\hline $\mathrm{CrS}=$ Estomatópodos, Crustacea & 7 & $\mathrm{Mi}=$ Microbiología & 3 & $\mathrm{Tn}=$ Tunicados & 5 \\
\hline $\mathrm{CrT}=$ Tanaidáceos, Crustacea & 2 & $\mathrm{Mg}=$ Manglares & 26 & $\mathrm{Ts}=$ Tsunami & 4 \\
\hline $\mathrm{CtB}=$ Contaminación, Bacterias & 1 & $\mathrm{MM}=$ Mamíferos Marinos & 17 & $\mathrm{Tu}=$ Turismo & 4 \\
\hline $\mathrm{CtC}=$ Contaminación, $\mathrm{PCB}$ & 2 & $\mathrm{Mn}=$ Monitoreo & 1 & VG = Vegetación Costera & 1 \\
\hline $\mathrm{CtM}=$ Contaminación, Metales & 3 & Mo $=$ Mollusca & 2 & $\mathrm{ZP}=$ Zonas Profundas & 6 \\
\hline $\mathrm{CtP}=$ Contaminación, Petróleo & 2 & MoB = Bivalvos, Mollusca & 37 & $\mathrm{ZR}=$ Zona Rocosa intermareal & 8 \\
\hline
\end{tabular}


CUADRO 2

Número de publicaciones por tipo de documento

TABLE 2

Number of publications by type of document

\begin{tabular}{|c|c|c|c|}
\hline Tipo de documento & \# Publ. & Tipo de documento & \# Publ. \\
\hline $\mathrm{AC}=$ Artículo científico & 487 & Mgr $=$ Monografía & 13 \\
\hline $\mathrm{Bb}=$ Bibliografía & 1 & $\mathrm{Mp}=$ Mapas & 1 \\
\hline $\mathrm{Co}=$ Colecciones $/$ museos & 5 & $\mathrm{Sm}=$ Simposio & 3 \\
\hline $\mathrm{Cp}=$ Capítulo de libro & 29 & $\mathrm{Te}=$ Tesis & 36 \\
\hline Inf $=$ Informes & 3 & $\mathrm{VE}=$ Volumen Especial/Suplemento & 2 \\
\hline $\mathrm{Li}=\mathrm{Libros}$ & 7 & & \\
\hline
\end{tabular}

con 15, de las zonas rocosas de entramarea (ocho) y de regiones profundas (seis) (Cuadro 1). Los organismos más estudiados son las tortugas marinas con 93 publicaciones, seguido por los crustáceos y dentro de ese grupo los decápodos (68 publicaciones), gasterópodos (60), bivalvos (37), antozoarios (27) y peces óseos (27) (Cuadro 1).

La inmensa mayoría de los trabjos son artículos científicos en revistas especializadas (486). Además, hay 29 capítulos de libros y un número importantes de tesis de grado y posgrado (36) (Cuadro 2).

La localidad más estudiada y por el mayor período de tiempo es Bahía Culebra, con 204 publicaciones, seguido por Bahía Santa Elena (90), Bahía Salinas (72), Playas del Coco (61) y las Islas Murciélago (52) (Cuadros 3 y 4, Fig. 1). Muchos de estos trabajos son sobre la presencia de especies de organismos marinos. De muchos sitios del Pacífico Norte hay una o dos publicaciones nada más, si es que hay algo publicado.

\section{DISCUSIÓN}

El Pacífico Norte de Costa Rica es una región de gran interés científico por su riqueza biológica y fenómenos océano-atmósfera, y de gran importancia nacional por las actividades económicas que se desarrollan allí. Adicionalmente, el Pacífico Norte junto con el Golfo de Nicoya (Vargas \& Mata 2004), Golfo Dulce (Quesada-Alízar 2006) y la Isla del Coco (Cortés, 2012d), son las regiones más estudiadas de Costa Rica. En el Pacífico Norte la región más estudiada es Bahía Culebra, no sólo en cantidad de publicaciones (Cuadro 3, Fig.1) sino también en diversidad de temas (Cortés 2012a). Aún así, falta mucho por conocer y es fundamental mantener monitoreos de los organismos y ambientes marinos ya que Bahía Culebra está cambiando rápidamente por la actividad humana y por disturbios naturales (Jiménez et al., 2001; Alvarado, Cortés \& Reyes-Bonilla 2012a; Sánchez-Noguera, 2012b).

A nivel centroamericano solamente la costa Pacífica de Panamá ha sido más estudiada que el Pacífico Norte de Costa Rica (ver publicaciones del Smithsonian Tropical Research Institute: http://www.stri.si.edu/english/about stri/index.php). Otra región relativamente bien estudiada es la costa de El Salvador y se han generado varias recopilaciones de información (e.g., MARN, 2011; Barraza, 2014).

Es recomendable ampliar las áreas geográficas de estudio en el Pacífico Norte de Costa Rica, para incluir regiones poco estudiadas o que no han sido investigadas del todo. De las 587 publicaciones citadas en este trabajo, más de la mitad fueron realizadas en seis de las 98 localidades indicads en el Cuadro 3. La gran mayoría de los sitios tiene una o dos publicaciones y hay secciones de la costa de donde no hay ninguna publicación. Se deben realizar más investigaciones sobre la biodiversidad marina y los procesos físico y químicos que la controlan, 
CUADRO 3

Número de publicaciones por localidad. Se dan las coordenadas de las localidades que no aparecen en los mapas 1:50 000 del Instituto Geográfico Nacional de Costa Rica (IGN). ACG = Área de Conservación Guanacaste,

RA $=$ Reserva Absoluta, RNVS $=$ Refugio Nacional de Vida Silvestre

TABLE 3

Number of publications by sites. The geographic coordinates of sites that are not included in the 1:50,000 maps of the National Geographic Institute of Costa Rica (IGN) are included. ACG = Guanacaste Conservation Area, $\mathrm{RA}=$ Absolute Reserve, $\mathrm{RNVS}=$ National Wildlife Refuge

\begin{tabular}{|c|c|c|c|c|c|}
\hline Localidad & \# Publ. & Localidad & \# Publ. & Localidad & \# Publ. \\
\hline $\mathrm{BC}=$ Bahía Culebra & 204 & IM = Islas Murciélago & 52 & $\mathrm{PF}=$ Playa Flamingo & 2 \\
\hline BEJ = Bahía El Jobo & 6 & & & $\mathrm{PG}=$ Playa Grande, $\mathrm{PNB}$ & 26 \\
\hline $\mathrm{BGu}=$ Bahía Guacamayo & 1 & IN = Islas Negritos & 2 & $\mathrm{PGa}=$ Punta Garza & 1 \\
\hline BU = Bahía Huevos & 7 & IP $=$ Islas Palmitas & 2 & $\mathrm{PGi}=$ Punta Guiones & 4 \\
\hline BJ = Bahía Juanilla & 2 & IPI = Isla Plata, Guanacaste & 1 & PH= Playa Hermosa, Guanacaste & 3 \\
\hline $\mathrm{Bl}=$ Bahía Ballena & 43 & $\mathrm{IT}=$ Islas Tortugas & 11 & PI = Playa Iguanita & 1 \\
\hline Bm = Bahía Tomás & 1 & IV = Isla Viradores & 5 & PIs = Punta Islita (Playa) & 2 \\
\hline BMt = Bahía Matapalito & 1 & $\mathrm{Ju}=$ Junquillal, $\mathrm{ACG}$ (Bahía, Playa) & 8 & $\mathrm{Pj}=$ Playa Naranjo, $\mathrm{ACG}$ & 6 \\
\hline BP = Bahía Potrero (Puerto, Playa) & 12 & JuN = Junquillal, Península de Nicoya & 2 & $\mathrm{PL}=$ Playa Langosta & 2 \\
\hline BS = Bahía Salinas & 72 & $\mathrm{LC}=\mathrm{La}$ Cruz & 1 & $\mathrm{PlA}=$ Playa Arío & 1 \\
\hline $\mathrm{BSE}=$ Bahía Santa Elena & 90 & $\mathrm{Ml}=$ Malpaís & 9 & PLg = Playa Lagarto & 1 \\
\hline BSJ = Bahía San Juanillo & 5 & $\mathrm{Mt}=$ Matapalo, Guancaste (Playa) & 7 & $\mathrm{PlH}=$ Playa El Hachal & 1 \\
\hline $\mathrm{Bt}=$ Bahía Brasilito & 13 & $\mathrm{Mz}=$ Montezuma & 8 & $\mathrm{Pn}=$ Punta Indio & 2 \\
\hline $\mathrm{CB}=$ Cabo Blanco (RA) & 38 & $\mathrm{Na}=$ Nancite (Playa) & 27 & PNB = Parque Nacional Las Baulas & 19 \\
\hline Cby $=$ Cabuya & 1 & No $=$ Nosara & 2 & PNJ = Playa Nombre de Jesús & 1 \\
\hline $\mathrm{Cj}=$ Cuajiniquil (Bahía, Playa) & 10 & Oc $=$ Ocotal (Playa) & 12 & Po $=$ Potrero Grande (Bahía, Playa) & 13 \\
\hline $\mathrm{Cl}=$ Carillo (Playa) & 6 & Os = Ostional (Playa, RNVS) & 25 & PPr = Playa Prieta & 1 \\
\hline $\mathrm{Cu}=$ Curú & 15 & $\mathrm{~Pa}=$ Punta Gorda & 1 & $\mathrm{PR}=$ Punta Pargos $10^{\circ} 12^{\prime} \mathrm{N}, 85^{\circ} 50^{\prime} \mathrm{W}$ & 4 \\
\hline Cy = Cabuyal (Playa, Punta) & 4 & Pam = Playa Panamá (Estero, manglar) & 6 & $\mathrm{PRe}=$ Playa Real & 1 \\
\hline DCR $=$ Domo de Costa Rica & 9 & $\mathrm{PaN}=$ Pacífico Norte & 15 & PSE = Península de Santa Elena & 10 \\
\hline $\mathrm{FCB}=$ Frente a Cabo Blanco & 7 & $\mathrm{PAv}=$ Playa Avellanas & 3 & PSM = Playa San Miguel & 2 \\
\hline $\mathrm{FCG}=$ Frente a la costa de Guanacaste & 26 & PB = Playa Blanca (Bahía) (Santa Elena) & 37 & PSR $=$ Parque Nacional Santa Rosa & 14 \\
\hline $\mathrm{FPC}=$ Frente a Playas del Coco & 1 & $\mathrm{PCa}=$ Punta Carbón & 1 & $\mathrm{Pt}=$ Pochote $($ Manglar, Punta $)$ & 10 \\
\hline $\mathrm{FPG}=$ Frente a Punta Guiones & 6 & PCh = Playa Conchal & 9 & Pty = Pitahaya: $10^{\circ} 04^{\prime} \mathrm{N} 85^{\circ} 46^{\prime} \mathrm{W}$ & 3 \\
\hline $\mathrm{GP}=$ Golfo de Papagayo & 49 & $\mathrm{PCt}=$ Playa Coyotera & 1 & $\mathrm{PZ}=$ Punta Zapotal & 1 \\
\hline Gua $=$ Guanacaste & 8 & PCy $=$ Punta Coyote & 6 & $\mathrm{PZl}=$ Zapotillal: $10^{\circ} 24^{\prime} \mathrm{N} 85^{\circ} 50^{\prime} \mathrm{W}$ & 1 \\
\hline $\mathrm{IB}=$ Isla Bolaños & 2 & $\mathrm{PD}=$ Punta Descartes & 3 & $\mathrm{Sr}=$ Sámara (Playa) & 43 \\
\hline $\mathrm{IC}=$ Isla Catalina $(\mathrm{ACG})$ & 1 & $\mathrm{PdC}=$ Playas del Coco (Bahía) & 61 & $\mathrm{Ta}=$ Tambor $($ Playa $)$ & 7 \\
\hline $\mathrm{ICa}=$ Islas Santa Catalina & 6 & Pen $=$ Punta Penca & 2 & $\operatorname{Tr}=$ Tamarindo & 31 \\
\hline ILC $=$ Isla Los Cabros & 1 & & & & \\
\hline
\end{tabular}

como también el impacto de la actividad humana directa a nivel local como indirecta por el cambio climático (Hidalgo \& Alfaro, 2012; Hidalgo, Amador, Alfaro \& Quesada, 2013). Los monitoreos existentes, solamente en Bahía Salinas y Bahía Culebra, se deben reforzar, ampliar en cuanto a los parámetros monitoreados y extender a otras zonas del Pacífico Norte y otras regiones del país. Éstos deben enfocarse en valorar los cambios positivos y negativos relacionados a la actividad humana y las medidas de manejo que se toman o no. Un campo nuevo de investigación es la conectividad de los ecosistemas del Pacífico Norte de Costa Rica con otras regiones del país y del Pacífico Tropical Oriental. Para ésto se requieren más 
CUADRO 4

Localidades dentro de cada uno de los cuadrantes de la Figura 1, según los mapas 1:50 000 del IGN.

En paréntesis el número de publicaciones de esa región

TABLE 4

Sites within each quadrant in Figure 1, based on the 1:50 000 of the IGN.

In parenthesis the number of publications of that region.

1. Bahía de Salinas (85): $\quad$ Bahía El Jobo (BEJ), Bahía Salinas (BS), Isla Bolaños (IB), La Cruz (LC), Playa Coyotera (PCt), Punta Descartes (PD)

2. Murciélago (21): $\quad$ Bahía Juanilla (BJ), Bahía Matapalito (1), Cuajiniquil (Cj), Junquillal, ACG (Ju)

3. Santa Elena (206): Bahía Tomás (Bm), Bahía Santa Elena (BSE), Isla Catalina (IC), Isla Los Cabros (ILC), Islas Murciélago (IM), Playa Blanca (PB), Playa El Hachal (PlH), Potrero Grande (Po), Península de Santa Elena (PSE)

4. Ahogados (47):

Nancite (Na), Playa Naranjo, ACG (Pj), Parque Nacional Santa Rosa (PSR)

5. Punta Gorda (10):

Bahía Guacamaya (BGu), Matapalo (Mt), Punta Gorda (Pa), Punta Zapotal (PZ)

6. Carillo Norte (304):

Bahía Culebra (BC), Bahía Huevos (BU), Cabuyal (Cy), Islas Palmitas (IP), Isla Viradores (IV), Ocotal (Oc), Playa Panamá (Pam), Playas del Coco (PdC), Playa Hermosa (PH), Playa Iguanita (PI)

7. Matapalo (94):

Bahía Potrero (BP), Bahía Brasilito (Bt), Islas Santa Catalina (ICa), Isla Plata (IPl), Punta Carbón (PCa), Playa Conchal (PCh), Punta Penca (Pen), Playa Flamingo (PF), Playa Grande (PG), Parque Nacional Marino Las Baulas (PNB), Playa Nombre de Jesús (PNJ), Playa Prieta (PPr), Playa Real (PRe), Zapotillal (PZl)

8. Villareal (42):

Junquillal (JuN), Playa Avellanas (PAv), Playa Langosta (PL), Punta Pargos (PR), Tamarindo (Tr)

9. Marbella (4):

Playa Lagarto (PLg), Pitahaya (Pty)

10: Cerro Brujo (29):

Bahía San Juanillo (BSJ), Ostional (Os)

11. Garza (52):

Nosara (No), Punta Garza (PGa), Punta Guiones (PGi), Punta Indio (Pn), Sámara (Sr)

12. Cerro Azul (8):

Carillo (Cl), Punta Islita (PIs)

13. Punta Coyote (8):

Punta Coyote (PCy), Playa San Miguel (PSM)

14. Río Arío (51):

Bahía Ballena (Bl), Playa Arío (PlA), Tambor (Ta)

15. Tambor (38):

Curú (Cu), Islas Negritos (IN), Islas Tortugas (IT), Pochote (Pt)

16. Cabuya (58):

Cabo Blanco (CB), Cabuya (Cby), Malpaís (Ml), Montezuma (Mz)

17. Mar afuera (98):

Domo de Costa Rica (DCR), Frente a Cabo Blanco (FCB), Frente a la costa de Guanacaste (FCG), Frente a Playas del Coco (FPC), Frente a Punta Guiones (FPG), Golfo de Papagayo (GP) 


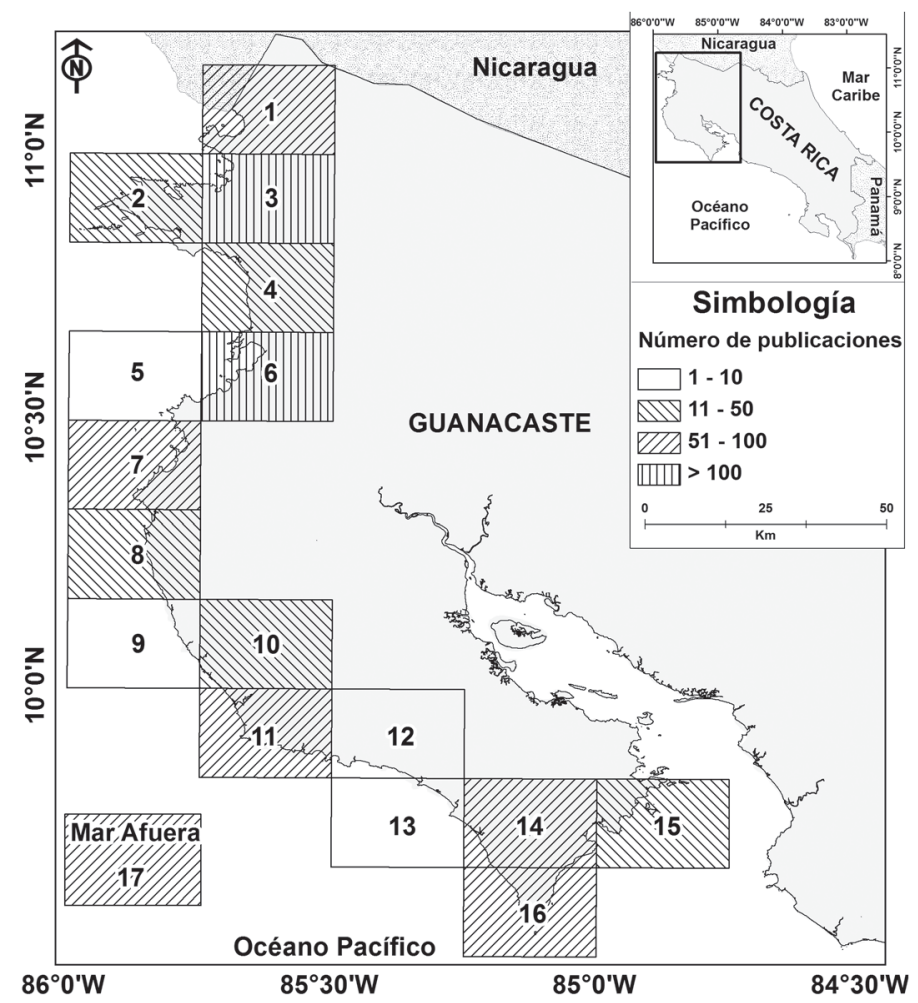

Fig. 1. Número de publicaciones por cuadrante (ver Cuadro 4) de la costa del Pacífico Norte de Costa Rica.

Fig. 1. Number of publications by quadrant (see Table 4) of the North Pacific coast of Costa Rica.

estudios sobre circulación oceánica pero también iniciar estudios genéticos para determinar la conectividad entre poblaciones.

En conclusión, se necesita realizar más estudios científicos sobre los organismos, ecosistemas y procesos marinos y atmosféricos que se dan en el Pacífico Norte de Costa Rica, para poder gestionar en forma integral la región.

\section{AGRADECIMIENTO}

Agradezco a todas las personas que me han ayudado a través de los años a mantener la base de datos de publicaciones sobre temas marinos en Costa Rica, en especial a Kay Hale, exDirectora de la Biblioteca de RSMAS, Universidad de Miami. Agradezco a Eric Alfaro, Randall Arauz, Gabriela S. Blanco, Cindy Fernández García, Omar Lizano, Astrid Sánchez,
Celeste Sánchez Noguera y a dos revisores anónimos por la revisión de este manuscrito y/o sus contribuciones con literatura sobre el Pacífico Norte de Costa Rica. Le agradezco mucho a Raquel Romero Chaves por su ayuda con el mapa. Finalmente, agradezco a la Agencia Alemana de Cooperación GiZ através del Proyecto BIOMARC por el apoyo económico, y a la Asociación Costa Rica por Siempre, como también a la Vicerrectoría de Investigación de la Universidad de Costa Rica a través del proyecto $808-\mathrm{B} 2-400$.

\section{RESUMEN}

El Pacífico Norte de Costa Rica es una región biológicamente rica y de gran importancia económica para el país. Allí se da el fenómeno de surgencia entre diciembre y abril-mayo, cuando los Vientos Alisios mueven las aguas cálidas superficiales mar afuera y son sustituidas por aguas 
profundas, frías, ricas en nutrientes y con altas concentraciones de $\mathrm{CO}_{2}$. Este cambio estacional tiene consecuencias importantes para los organismos marinos. Este trabajo tiene el objetivo de recopilar todas las publicaciones disponibles sobre investigación marina y atmosférica en el Pacífico Norte de Costa Rica. Se ubicaron 587 documentos sobre organismos, ambientes, y procesos marinos, oceanográficos y atmosféricos. La mayoría son sobre biodiversidad, con descripciones y listas de especies, seguido por trabajos ecológicos. Hay pocas publicaciones sobre otros temas. Los manglares son los ecosistemas costeros más estudiados, seguido por los arrecifes coralinos; mientras que, de otros hay pocas publicaciones, si es que hay. Las tortugas marinas, crustáceos decápodos y moluscos son los organismos de los que hay más publicaciones, seguidos por bivalvos y peces. Bahía Culebra es el área más estudiada, con muchas más publicaciones que otras localidades, seguido por Bahía Santa Elena. La gran mayoría de las publicaciones son artículos científicos en revistas especialisadas (487). Además, hay un número importante de tesis, 36. La cantidad y diversidad de investigaciones publicadas sobre el Pacífico Norte es relativamente alta pero se debe continuar estudiando la región y los monitoreos se deben reforzar y expander. El Pacífico Norte de Costa Rica es una región cambiando rápidamente y se debe contar con la información científica para una gestión sostenible de sus ambientes marinos.

Palabras clave: bibliografía, Costa Rica, ambientes marinos, ciencias marinas, meteorología.

\section{Lista de publicacionesdel Pacífico Norte de Costa Rica. En paréntesis los código temáticos y de localidades definidos en los Cuadros 1, 2 y 3, respectivamente}

\section{List of publicaciones from the North Pacific of Costa Rica. In parenthesis the codes used for topics and locations, as defined in Tables 1, 2 and 3, respectively}

Acuña, F. H., Garese, A., Excoffon, A. C. \& Cortés, J. (2013). New records of sea anemones (Anthozoa: Actiniaria from Costa Rica. Revista de Biología Marina y Oceanografia, 48, 177-184. (AC, BC, Bd, $\mathrm{CnA}, \mathrm{Ml})$

Acuña, J. A., Cortés, J. \& Murillo, M. M. (1996-1997). Mapa de sensibilidad ambiental para derrames de petróleo en las costas de Costa Rica. Revista de Biología Tropical, 44(3)/45(1), 463-470. (AC, BC, CtP)

Acuña-González, J. A., Vargas-Zamora, J. A., GómezRamírez, E. \& García-Céspedes, J. (2004). Hidrocarburos de petróleo, disueltos y dispersos, en cuatro ambientes costeros de Costa Rica. Revista de Biología Tropical, 52 (Suplemento 2), 43-50. (AC, BC, $\mathrm{CtP})$

Acuña-Mesén, R. A. (1980). Aspectos de la fase terrestre de la tortuga lora Lepidochelys olivacea.Tesis de Maestría, Universidad de Costa Rica, San Pedro, Costa Rica. 116 p. (Arb, Os, Te, TM)

Aguirre, A. A. \& Lutz, P. L. (2004). Marine turtles as sentinels of ecosystem health: Is fibropapillomatosis an indicator? EcoHealth, 1, 275-283. (AC, En,Os, TM)

Aguirre, A. A., Spraker, T. R., Chaves-Quiroz, A., du Toit, L. A. \& Balazs, G. H. (1999). Histopathology of fibropapillomatosis in olive ridley turtles Lepidochelys olivacea nesting in Costa Rica. Journal of
Aquatic Animal Health, 11, 283-289. (AC, En, Os, TM)

Ajtai, P., Camacho-García, Y. \& Wehrtmann, I. S. (2003). Range extension of Crosslandia daedali (Nudibranchia: Scyllaeidae). Revista de Biología Tropical, 51: 274. (AC, BC, Bg, MoG)

Alfaro, E. J. (1998). Influencia de los Océanos Pacífico y Atlántico Tropical sobre los patrones de precipitación en Centroamérica. Tesis Doctoral, Universidad de Concepción, Concepción, Chile. (CA, Te)

Alfaro, E. J. (2000). Response of air surface temperatures over Central America to Oceanic Climate Variability Indices. Tópicos Meteorológicos y Oceanográficos, 7(2), 63-72. (AC, CA)

Alfaro, E. J. (2002). Some characteristics of the annual precipitation cycle in Central America and their relationships with its surrounding tropical oceans. Tópicos Meteorológicos y Oceanográficos, 9(2), 88-103. (AC, CA)

Alfaro, E. J. (2014). Caracterización del Veranillo en dos cuencas de la vertiente del Pacífico de Costa Rica, América Central. Revista de Biología Tropical, 62 (Suplemento 4), 1-15. (AC, CA)

Alfaro, E. J. \& Cid, L. (1999). Análisis de las anomalías en el inicio y el término de la estación lluviosa en Centroamérica y su relación con los océanos Pacífico 
y Atlántico Tropical. Tópicos Meteorológicos y Oceanográficos, 6(1), 1-13. (AC, CA)

Alfaro, E. J. \& Cortés, J. (2012). Atmospheric forcing of cool subsurface water events in Bahía Culebra, Costa Rica. Revista de Biología Tropical, 60 (Suplemento 2), 173-186. (AC, Af, BC, CA, OF)

Alfaro, E. J. \& Lizano, O. G. (2001). Algunas relaciones entre las zonas de surgencia del Pacífico Centroamericano y los océanos Pacífico y Atlántico tropicales. Revista de Biología Tropical, 60 (Suplemento 2), 185 193. (AC, Af, CA, GP, OF)

Alfaro, E. J., Cid, L. \& Enfield, D. (1998). Relaciones entre el inicio y el término de la estación lluviosa en Centroamérica y los Océanos Pacífico y Atlántico Tropical. Investigaciones Marinas, 26, 59-69. (AC, CA)

Alfaro, E. J., Hernández, D. \& Bezanilla, A. (2007). Uso de un modelo de aguas someras para analizar la influencia del Atlántico Tropical Norte y del Pacífico Ecuatorial del Este sobre la circulación atmosférica en los mares Intra-Americanos. Revista de Climatología, 7, 15-26. (AC, CA)

Alfaro, E. J., Cortés, J., Alvarado, J. J., Jiménez, C., León, A., Sánchez-Noguera, C., Nivia-Ruiz, J. \& RuizCampos, E. (2012). Clima y variabilidad climática de la temperatura subsuperfical del mar en Bahía Culebra, Guanacaste, Costa Rica. Revista de Biología Tropical, 60 (Suplemento 2), 159-171. (AC, Af, BC, $\mathrm{CA}, \mathrm{OF})$

Alpermann, T.J. 2001. The fisheries of ornamental fishes in Guanacaste, Costa Rica with special emphasis on the population dynamics of the Cortez Rainbow wrasse, Thalassoma lucasanum (Gill 1863). Tesis de Maestría, ISATEC, Universidad de Bremen. Bremen, Alemania. 84 p. (BC, Eg, Pe, PiA, Te)

Alvarado. J. J. (2008). Seasonal occurrence and aggregation behavior of the sea urchin Astropyga pulvinata (Echinodermata: Echinoidea) in Bahía Culebra, Costa Rica. Pacific Science, 62, 579-592. (AC, BC, Eg, $\mathrm{EcE})$

Alvarado, J. J. \& Cortés, J. (2009). Echinoderms. In I. S. Wehrtmann \& J. Cortés (Eds.), Marine Biodiversity of Costa Rica, Central America (Texto: pp. 421-433, Lista de especies: Disco Compacto pp. 392-408). Berlin: Springer. (BC, Bd, BS, Cp, Ec,)

Alvarado, J. J. \& Vargas-Castillo, R. (2012). Invertebrados asociados al coral Pocillopora damicornis (Linnaeus, 1758) en Playa Blanca, Bahía Culebra, Costa Rica. Revista de Biología Tropical, 60 (Suplemento 2), 77-92. (AC, BC, Bd, CnA, Eg, Ec)

Alvarado, J. J., Herrera, B., Corrales, L., Asch, J. \& Paaby, P. (2011). Identificación de las prioridades de conservación de la biodiversidad marina y costera en Costa Rica. Revista de Biología Tropical, 59, 829-842. (AC, AMP, Bd, BSE, CB, Cu, Cv, GP, IT, Os, Pa, PD, Pn, PP, Ta)
Alvarado, J. J., Cortés, J. \& Reyes-Bonilla, H. (2012a). Bioerosion impact model of the sea urchin Diadema mexicanum on three Costa Rican Pacific coral reefs. Revista de Biología Tropical, 60 (Suplemento 2), 121 132. (AC, BC, Bi, EcE, Eg)

Alvarado, J. J., Cortés, J., Esquivel, M. F. \& Salas, E. (2012b). Costa Rica's Marine Protected Areas: review and perspectives. Revista de Biología Tropical, 60, 129-142. (AC, AMP, Cv, Lg, PaN, PSR)

Alvarado-Barrientos, J. J. (2012). Estado e impacto de Diadema mexicanum A. Agassiz, 1863 (Echinoidea) en los arrecifes coralinos del Pacífico Tropical Oriental. Disertación doctoral, Posgrado en Ciencias Marinas y Costeras, Universidad Autónoma de Baja California Sur, La Paz, Baja California Sur, México. 192 p. (BC, $\mathrm{Bi}, \mathrm{EcE}, \mathrm{Eg}, \mathrm{Te})$

Alvarado-Quesada, G. M. (2006). Conservación de las aves acuáticas de Costa Rica. Brenesia, 66, 49-68. (AC, Av, $\mathrm{BS}, \mathrm{CB}, \mathrm{Cv}, \mathrm{IB}, \mathrm{ICa})$

Amador, J. A., Alfaro, E. J., Lizano, O. G. \& Magaña, V. O. (2006). Atmospheric forcing in the Eastern Tropical Pacific: A review. Progress in Oceanography, 69, 101-142. (AC, CA, GP, OF)

Arana, P. M., Wehrtmann, I. S., Orellana, J. C., NielsenMuñoz, V. \& Villalobos-Rojas, F. (2013). By-catch associated with fisheries of Heterocarpus vicarius (Costa Rica) and Heterocarpus reedi (Chile) (Decapoda: Pandalidae): a six-year study (2004-2009). Journal of Crustacean Biology, 33, 198-209. (AC, CrD, Eg, FCG, Pe)

Arndt, R. G. (1999). Predation by the black iguana (Ctenosaura similis) on the painted ghost crab (Ocypode gaudichaudii) in Costa Rica. Florida Scientist, 62, 111-114. (AC, Cu, Eg, CrD, Rp)

Arroyo-Mora, D. (1998). Crecimiento y reproducción de Strombus galeatus (Gastropoda: Strombidae) en el Pacifico de Costa Rica. Revista de Biología Tropical, 46 (Suplemento 6), 27-36. (AC, CB, Eg, MoG)

Arroyo-Mora, D. \& Mena, L. (1998). Estructura de la población del cambute Strombus galeatus (Gastropoda: Strombidae) en Cabo Blanco, Costa Rica. Revista de Biología Tropical, 46 (Suplemento 6), 37-46. (AC, $\mathrm{CB}, \mathrm{Eg}, \mathrm{MoG})$

Augener, H. (1922). Ueber litorale Polychaeten von Westindien. Gesellschaft Naturforschender Freunde zu Berlin 1922(3-5), 38-53. (AC, BC, Bd, Py)

Báez, A. L. 1985. Evaluación de algunos aspectos de la biología del molusco Polymoesoda inflata (Philippi, 1851) (Bivalvia Corbiculidae) manglar de Pochote, Puntarenas-Costa Rica. Tesis de Licenciatura en Biología, Universidad de Costa Rica, San Pedro. 74 p. $(\mathrm{Eg}, \mathrm{MoB}, \mathrm{Pt}, \mathrm{Te})$

Bailey, H., Benson, S. R., Shillinger, G. L., Bograd, S. J., Dutton, P. H., Eckert, S. A., Morreale, S. J., Paladino, 
F. V., Eguchi, T., Foley, D. G., Block, B. A., Piedra, R. Hitipeuw, C., Tapilatu, R. F. \& Spotila, J. R. (2012). Identification of distinct movement patterns in Pacific leatherback turtle populations influenced by ocean conditions. Ecological Applications, 22, 735-747. (AC, Eg, OF, PG, TM)

Ballance, L. T., Pitman, R. L. \& Fiedler, P. C. (2006). Oceanographic influences on seabirds and cetaceans of the eastern tropical Pacific: A review. Progress in Oceanography, 69, 360-390. (AC, Av, Eg, GP, MM, OF)

Ballestero, D. 2006. El Domo Térmico de Costa Rica. In V. Nielsen-Muñoz \& M. A. Quesada-Alpízar (Eds.), Ambientes Marino-Costeros de Costa Rica (pp. 69-85). Comisión Interdisciplinaria Marino Costera de la Zona Económica Exclusiva de Costa Rica, Informe Técnico. San José, Costa Rica: CIMAR, CI, TNC. (DTC, Inf, OF)

Ballestero, D. \& Coen, J. E. (2004). Generation and propagation of anticyclonic rings in the Gulf of Papagayo. International Journal of Remote Sensing 25, 22172224. (AC, GP, OF)

Bandy, O. L. \& Arnal, R. E. (1957). Distribution of Recent Foraminifera off the west coast of Central America. Bulletin of the American Association of Petroleum Geologists, 41, 2037-2053. (AC, BC, Bd, Bg, Fo)

Banta, W. C. \& Carson, R. J. M. (1977). Bryozoa from Costa Rica. Pacific Science, 31, 381-424. (AC, Bd, $\mathrm{Br}, \mathrm{PdC})$

Barham, E. G. (1979). Giant larvacean houses: observations from deep submersibles. Science, 205, 1129-1131. (AC, Ap, FCG, ZP)

Barnard, J. L. (1954). Amphipoda of the family Ampelisceidae collected in the eastern Pacific by the Velero III and Velero IV. Allan Hancock Pacific Expeditions, 18, 1-137. (AC, BC, Bd, BS, BSE, CrA, PB, PdC)

Barnard, J. L. (1980). Revision of Metharpinia and Microphoxus (marine Phoxocephalid Amphipoda from the Americas). Proceedings of the Biological Society of Washington, 93, 104-135. (AC, Bd, BS, CrA, PB)

Barnard, J. L. \& Barnard, C. M. (1982). Revision of Foxiphalus and Eobrolgus (Crustacea: Amphipoda: Phoxocephalidae) from American Oceans. Smithsonian Contributions to Zoology, 372, 1-35. (AC, BC, Bd, BS, CrA)

Bassey-Fallas, G. (2010). Evaluación ecológica de los arrecifes y comunidades coralinas de las Islas Murciélago y sección norte de la Península de Santa Elena en el Pacífico de Costa Rica. Maestría en Ciencias Marinas y Costeras, Universidad Nacional, Heredia, Costa Rica. 124 p. (Ar, IM, PSE, Te)

Bednarski, M. (2001). Macrozooplankton of Culebra Bay, Costa Rica, with an emphasis on copepods. Tesis de Maestría, ISATEC, Universidad de Bremen. Bremen, Alemania. 155 p. (BC, Bd, Bin, Eg, PlZ, Te)
Bednarski, M. \& Morales-Ramírez, A. (2004). Composition, abundance and distribution of macrozooplankton in Culebra Bay, Gulf of Papagayo, Pacific coast of Costa Rica and its value as bioindicator of pollution. Revista de Biología Tropical, 52 (Suplemento 2), 105-118. (AC, BC, Bd, Bin, Eg, PlZ)

Beebe, W. (1938). Eastern Pacific expeditions of the New York Zoological Society, XIV. Introduction, itinerary, list of stations, nets and dredges of the eastern Pacific Zaca expedition, 1937-1938. Zoologica, 23, 287-298. (AC, BC, Bl, BSE, Bt, CB, IM, Po,Sr)

Beebe, W. (1942). Book of Bays. New York: Barcourt, Brace and Company. 302 p. (BC, BSE, IM, Li, Po)

Beebe, W. (1942). Eastern Pacific expeditions of the New York Zoological Society, XXX. Atlantic and Pacific fishes of the genus Dixonina. Zoologica, 27, 43-48. (AC, BC, Bd, PiA)

Bell, B. A., Spotila, J. R., Paladino, F. V. \& Reina, R. D. (2003). Low reproductive success of leatherback turtles, Dermochelys coriacea, is due to high embryonic mortality. Biological Conservation, 115, 131-138. (AC, Eg, PG, TM)

Bernecker, A. \& Wehrtmann, I. S. (2009). New records of benthic marine algae and Cyanobacteria for Costa Rica, and a comparison with other Central American countries. Helgoland Marine Research, 63, 219-229. (AC, Al, Bd, BS, Sr)

Berry, S .S. (1958). Notices of new eastern Pacific Mollusca - II. Leaflets in Malacology, 1, 83-90. (AC, BC, $\mathrm{Bd}, \mathrm{MoG})$

Bezy, M.B. 2009. Reproducción sexual y reclutamiento del coral masivo, Pavona clavus, en Bahía Culebra, Golfo de Papagayo, Costa Rica. Tesis de Maestría, Universidad de Costa Rica. San Pedro, Costa Rica. 151 p. (CnA, BC, Eg, Te)

Bezy, M. B., Jiménez, C. Cortés, J., Segura, A., León, A., Alvarado, J. J., Gillén, C. \& Mejía, E. (2006). Contrasting Psammocora-dominated coral communities in Costa Rica, tropical eastern Pacific. Proceedings of the 10th International Coral Reef Symposium, Okinawa, 376-381. (CnA, BC, Eg, Sm)

Bianchi, G. (1991). Demersal assemblages of the continental shelf and slope edge between the Gulf of Tehuantepec (Mexico) and the Gulf of Papagayo (Costa Rica). Marine Ecology Progress Series, 73, 121-140. (AC, Bd, Cr, GP)

Bigelow, H. B. (1940). Eastern Pacific Expeditions of the New York Zoological Society. XX. Medusae of the Templeton Crocker and Eastern Pacific Zaca Expeditions, 1936-1938. Zoologica, 25, 281-321. (AC, Bd, CnM, FCB)

Bilinski, J. J., Reina, R. D., Spotila, J. R. \& Paladino, F. V. (2001). The effects of nest environment on calcium mobilization by leatherback turtle embryos 
(Dermochelys coriacea) during development. Comparative Biochemistry and Physiology. A: Comparative Physiology, 130, 151-162. (AC, Eg, PG, TM)

Binckley, C. A, Spotila, J. R., Wilson, K. S. \& Paladino, F. V. (1998). Sex determination and sex ratios of Pacific leatherback turtles, Dermochelys coriacea. Copeia, 2, 291-300. (AC, Eg, PG, TM)

Blanco, G. S. \& Santidrián, P. (2011). La tortuga marina negra de Guanacaste amenazada de extinción por prácticas humanas. Ambientales, 41, 19-26. (AC, Cv, Cy, Mt, PNJ, PPr, PZl, TM)

Blanco, G. S., Morreale, S. J., Bailey, H., Seminoff, J. A., Paladino, F. V. \& Spotila, J. R. (2012). Post-nesting movements and feeding grounds of a resident East Pacific green turtle Chelonia mydas population from Costa Rica. Endangered Species Research, 18, 233245. (AC, Cv, Eg, GP, TM)

Blanco, G. S., Morreale, S. J., Vélez, E., Piedra, R., Montes, W. N., Paladino, F. V. \& Spotila, J. R. (2012). Reproductive output and ultrasonography of an endangered population of East Pacific Green Turtles. The Journal of Wildlife Management, 76(4), 841-846. (AC, Eg, Gua, TM)

Blanco, G. S., Morreale, S. J., Seminoff, J. A., Paladino, F. V., Piedra, R. \& Spotila, J. R. (2013). Movements and diving behavior of internesting green turtles along Pacific Costa Rica. Integrative Zoology, 8, 293-306. (AC, Cv, Eg, Gua, TM)

Böggemann, M. (2002). Revision of the Glyceridae Grube 1850 (Annelida: Polychaeta). Abhandlungen der Senckenbergischen Naturforschenden Gesellschaft, 555, 1-249. (AC, Cl, Mz, PF, PGi, PIs, Py, Sr)

Bolaños, R., Flores, A., Taylor, R. T. \& Cerdas, L. (1974). Color patterns and venom characteristics in Pelamis platurus. Copeia, 1974, 909-912. (AC, Eg, BC, Rp)

Bonoff, M. B. \& Janzen, D. H. (1980). Small terrestrial rodents in eleven habitats in Santa Rosa National Park, Costa Rica. Brenesia, 17, 163-174. (AC, Bd, MdM, Mg, PSR)

Boulay, J. N., Hellberg, M. E., Cortés, J. \& Baums, I. B. (2014). Unrecognized coral species diversity masks differences in functional ecology. Proceedings of the Royal Society B, 281, 20131580. (AC, BSJ, CnA, $\mathrm{Eg}, \mathrm{Gn})$

Bousfield, E. L. (1982). The amphipod Superfamily Talitroidea in the northeastern Pacific region. I. Family Talitridae: Systematics and distributional ecology. National Museum of Natural Sciences Publications in Biological Oceanography, 11, 1-73. (AC, Bd, CrA, PdC)

Bowen, B. W. Clark, A. M., Abreu-Grobois, F. A., Chaves, A., Reichart H. A. \& Ferl, R. J. (1998) Global phylogeography of the ridley sea turtles (Lepidochelys spp.) as inferred from mitochondrial DNA sequences. Genetica, 101, 179-189. (AC, Fg, Gn, Na, TM)
Bratcher, T. \& Burch, R. D. (1971). The Terebridae (Gastropoda) of Clarion, Socorro, Cocos and Galápagos islands. Proceedings of the California Academy of Sciences, $4^{\text {th }}$ Series, 37, 537-566. (AC, Bd, GP, MoG)

Bravo, J. \& Rivera, L. (1998). Mapas de Humedales de Costa Rica e Información Complementaria. San José, Costa Rica: SINAC, MINAE-UICN. Escala 1: 200 000. ( $\mathrm{Hu}, \mathrm{Mp}, \mathrm{PaN})$

Breedy, O. (2009). Octocorals. In I. S. Wehrtmann \& J. Cortés (Eds.), Marine Biodiversity of Costa Rica, Central America (Texto: pp. 161-167, Lista de especies: Disco Compacto pp. 108-111). Berlin: Springer. (BC, Bd, $\mathrm{CnA}, \mathrm{Cp})$

Breedy, O. \& J. Cortés. (2014). Gorgonias (Anthozoa: Octocorallia: Gorgoniidae) de las aguas someras del Pacífico Norte de Costa Rica. Revista de Biología Tropical, 62 (Suplemento 4), 43-62. (AC, Bd, BS, BSE, BSJ, CB, Cby, CnA, IM, Sr)

Breedy, O. \& Guzmán, H. M. (2002). A revision of the genus Pacifigorgia (Coelenterata: Octocorallia: Gorgoniidae). Proceedings of the Biological Society of Washington, 115, 782-839. (AC, BC, Bd, CB, CnA, $\mathrm{IM}, \mathrm{Ml}, \mathrm{Sr}$ )

Breedy, O. \& Guzmán, H. M. (2003). Octocorals from Costa Rica: The genus Pacifigorgia (Coelenterata: Octocorallia: Gorgoniidae). Zootaxa, 281, 1-60. (AC, $\mathrm{BC}, \mathrm{Bd}, \mathrm{BSE}, \mathrm{CB}, \mathrm{Cj}, \mathrm{Cl}, \mathrm{CnA}, \mathrm{IM}, \mathrm{Sr})$

Breedy, O. \& Guzmán, H. M. (2005). A new species of Leptogorgia (Coelenterata: Octocorallia: Gorgoniidae) from the shallow waters of the eastern Pacific. Zootaxa, 899, 1-11. (AC, BC, Bd, BS, CnA, IM)

Breedy, O. \& Guzmán, H. M. (2007). A revision of the genus Leptogorgia Milne Edwards \& Haime, 1857 (Coelenterata: Octocorallia: Gorgoniidae) in the eastern Pacific. Zootaxa, 1407, 1-90. (AC, BC, Bd, BS, $\mathrm{CB}, \mathrm{CnA}, \mathrm{IM}, \mathrm{Sr}$ )

Breedy, O. \& Guzmán, H. M. (2008). Leptogorgia ignita, a new shallow-water coral species (Octocorallia: Gorgoniidae) from the tropical eastern Pacific. Journal of the Marine Biological Association of the United Kingdom, 88, 893-899. (AC, Bd, CnA, Sr)

Breedy, O. \& Guzmán, H. M. (2011). A revision of the genus Heterogorgia Verrill, 1868 (Coelenterata: Octocorallia: Plexauridae. Zootaxa, 2995, 27-44. (AC, BC, Bd, CnA, PNB)

Breedy, O. \& Guzmán, H. M. (2013). A new species of the genus Eugorgia Verrill, 1868 (Cnidaria: Octocorallia: Gorgoniidae) from mesophotic reefs in the eastern Pacific. Bulletin of Marine Science, 89, 735-743. (AC, BSE, CnA, ZP)

Breedy, O., Guzmán, H. M. \& Vargas, S. (2009). A revision of the genus Eugorgia Verrill, 1868 (Coelenterata: Octocorallia: Gorgoniidae). Zootaxa, 2151, 1-46. (AC, Bd, BSE, CnA, IM, Sr) 
Brenes, C. L. \& Coen, E. (1985). Correlación T-S de las masas de agua en la región del Domo Térmico de Costa Rica. Uniciencia, 2(1), 41-50. (AC, DCR, OF)

Brenes, C. L., Kwiecinski, B., D’Croz, L. \& Chaves C., J. (1995). Características oceanográficas de la plataforma Pacifica de América Central y aguas oceánicas adyacentes. Cruceros 25 set-18 oct 1993, 25 feb-18 marzo, 1994. Informe de Campañas. Panamá: PRADEPESCA, 73 p. (GP, Inf, OF)

Brenes, C. L., Lavín, M. F. \& Mascarenhas Jr., A. S. (2008). Geostrophic circulation between the Costa Rica Dome and Central America. Deep-Sea Research I, 55, 608-629. (AC, DCR, OF)

Brenes, C. L., Márquez, A., Quirós, W. \& Benavides, R. (2012). Rasgos hidrográficos y batimétricos del Refugio Nacional de Vida Silvestre Ostional y áreas adyacentes, Guanacaste, Costa Rica. Revista de Ciencias Marinas y Costeras, 4, 145-156, (AC, OF, Os)

Brenes-Chaves, L., Berrocal, A., Meneses, A. I., JiménezSánchez, C. \& Orrego-Vásquez, C. M. (2013). Study on the etiology of fibropapillomatosis of olive ridley sea turtles (Lepidochelys olivacea) nesting in the National Wildlife Refuge at Ostional, Guanacaste, Costa Rica. Revista de Ciencias Marinas y Costeras, 5, 119-134. (AC, En, Os, TM)

Bright, D. B. (1966). Land crabs of Costa Rica. Revista de Biología Tropical, 14, 183-203. (AC, Bd, CrD, PdC)

Broenkow, W. W. (1965). The distribution of nutrients in the Costa Rica Dome in the Eastern Tropical Pacific Ocean. Limnology and Oceanography, 10, 40-52. (AC, DCR, GP, OQ)

Brusca, R. C. \& Iverson, E. W. (1985). A guide to the marine Isopod Crustacea of Pacific Costa Rica. Revista de Biología Tropical, 33 (Suplemento 1), 1-77. (AC, Bd, $\mathrm{BC}, \mathrm{CrI}, \mathrm{Mg})$

Buck, L. (1990). Shell collecting off Playa de Cocos, Costa Rica. The Festivus, 22, 83-85. (AC, Bd, MoG, PdC)

Burch, J. Q. (1949). A new Trigonostoma from Central America. Minutes of the Conchological Club of Southern California, 94, 3-4. (AC, Bd, MoG, Ta)

Burger, J. \& Gochfeld, M (2014) Avian predation on olive ridley (Lepidochelys olivacea) sea turtle eggs and hatchlings: Avian opportunities, turtle avoidance, and Human protection. Copeia 2014(1):109-122. (AC, Arb, Cv, Eg, Os, TM)

Bussing, W. A. (1981). Elacatinus janssi, a new gobiid fish from Costa Rica. Revista de Biología Tropical, 29, 251-256. (AC, Bd, Bl, PiA)

Bussing, W. A. (1983). Evermannia erici, a new burrowing gobiid fish from the Pacific coast of Costa Rica. Revista de Biología Tropical, 31, 125-131. (AC, Bd, PiA, Tr)
Bussing, W. A. (1990). New species of gobiid fishes of the genera Lythrypnus, Elacatinus and Chriolepis. Revista de Biología Tropical, 38, 99-118. (AC, Bd, IM, PiA)

Bussing, W. A. (1991). A new genus and two new species of tripterygiid fishes from Costa Rica. Revista de Biología Tropical, 39, 77-85. (AC, Bd, BU, BP, BS, BSE, $\mathrm{IM}, \mathrm{Oc}, \mathrm{PbC}, \mathrm{PiA})$

Bussing, W. A. (1991). A new species of eastern Pacific moray eel (Pisces: Muraenidae). Revista de Biología Tropical, 39, 97-102. (AC, Bd, BU, Oc, PiA)

Bussing, W. A. (1998). Gymnothorax phalarus, a new eastern Pacific moray eel (Pisces: Muranidae). Revista de Biología Tropical, 46, 439-446. (AC, Bd, CB, M1, PCy, PiA)

Bussing, W. A. \& Lavenberg, R. J. (2003). Four new species of eastern tropical Pacific jawfishes (Opistongathus: Opistognathidae). Revista de Biología Tropical, 51, 529-550. (AC, Bd, IM, PiA)

Bussing, W. A. \& López, M. (2009). Marine fish. In I. S. Wehrtmann \& J. Cortés (Eds.), Marine Biodiversity of Costa Rica, Central America (Texto: pp. 453-458, Lista de especies: Disco Compacto pp. 412-473). Berlin: Springer. (BC, Bd, Cp, PiA)

Cabrera-Peña, J. \& Solano-López, Y. (1996). Tamaños y frecuencia de Pontonia margarita (Crustacea: Palaemonidae) asociada a Pinctada mazatlanica (Bivalvia: Pteriidae), Costa Rica. Revista de Biología Tropical, 44, 915-917. (AC, BC, CrD, Eg, MoB)

Cabrera-Peña, J., Vives-Jiménez, F. \& Solano-López, Y. (1994). Tamaños y relación sexual de Ucides occidentalis (Crustacea: Gecarcinidae) en el manglar de Estero Panamá, Bahía Culebra. Uniciencia, 11, 97-99. (AC, $\mathrm{BC}, \mathrm{CrD}, \mathrm{Eg}, \mathrm{Mg}, \mathrm{Pam})$

Cabrera-Peña, J., Cruz, R. A., Solano-López, Y. \& Protti Q., M. (1995). Biometría de Modiolus capax (Bivalvia: Mytilidae) en Playa Ocotal, Guanacaste, Costa Rica. Revista de Biología Tropical, 43, 173-176. (AC, $\mathrm{Eg}, \mathrm{MoB}, \mathrm{Oc})$

Cajiao, M. V. (2012). Aspectos legales del Polo Turístico Golfo de Papagayo, Guanacaste, Costa Rica: régimen especial. Revista de Biología Tropical, 60 (Suplemento 2), 225-230. (AC, BC, Lg)

Calambokidisl, J., Steiger, G. H., Ramussen, K., Urbán R., J., Balcomb, K. C., Ladrón de Guevara P., P., Salinas Z., M., Jacobsen, J. K., Baker, C. S., Herman, L. M., Cerchio, S. \& Darling, J. D. (2000). Migratory destinations of humpback whales that feed off California, Oregon and Washington. Marine Ecology Progress Series, 192, 295-304. (AC, FCG, MM)

Camacho-García, Y. E. \& Gosliner, T. M. (2004). A new species of Okenia (Gastropoda: Nudibranchia: Goniodoridae) from the Pacific coast of Costa Rica. Proceedings of the California Academy of Sciences, 55, 431-438. (AC, Bd, MoG, Tr) 
Camacho-García, Y. E. \& Gosliner, T. M. (2006). A new species of the zephyrinid nudibranch genus Janolus (Mollusca: Nudibranchia) from North America and Costa Rica. Revista de Biología Tropical, 54, 1295 1305. (AC, Bd, IPl, MoG)

Camacho-García, Y. E. \& Gosliner, T. M. (2008). Systematic revision of Jorunna Bergh, 1876 (Nudibranchia: Discodorididae) with a morphological phylogenetic analysis. Journal of Molluscan Studies, 74, 143-181. (AC, Bd, CB, MoG, PCh, PAv)

Camacho-García, Y. E. \& Gosliner, T. M. (2008). Nudibranch dorids from the Pacific coast of Costa Rica with description of a new species. Bulletin of Marine Science, 83, 367-389. (AC, Bd, CB, ICa, IM, MoG, $\mathrm{PCa}, \mathrm{PCh}, \mathrm{PRe}, \mathrm{PAv})$

Camacho-García, Y. \& Ortea, J. (2000). A new species of Trapania (Nudibranchia: Goniodorididae) from the Pacific coast of Central America. Revista de Biología Tropical, 48, 317-322. (AC, Bd, CB, MoG)

Camacho-García, Y. E. \& Valdés, Á. (2003). Caryophyllidiabearing dorid nudibranchs (Mollusca, Nudibranchia, Doridacea) from Costa Rica. Proceedings of the California Academy of Sciences, 54, 65-79. (AC, Bd, $\mathrm{CB}, \mathrm{MoG})$

Camacho-García Y. E., Ornelas-Gatdula, E., Gosliner, T. M. \& Valdés, Á. (2013). Phylogeny of the family Aglajidae (Pilsbry, 1895) (Heterobranchia: Cephalaspidea) inferred from mtDNA and nDNA. Molecular Phylogenetics and Evolution, 71, 113-126. (AC, Gn, MoG, Sr)

Camp, D. K. \& Kuck, H. G. (1990). Additional records of stomatopods crustaceans from Isla del Coco and Golfo de Papagayo, east Pacific Ocean. Proceedings of the Biological Society of Washington, 103, 847-853. (AC, $\mathrm{Bd}, \mathrm{CrS}, \mathrm{GP})$

Campbell, L. M. (1998). Use them or lose them? The consumptive use of marine turtle eggs at Ostional, Costa Rica. Environmental Conservation, 24, 305-319. (AC, Arb, Cv, Os, Rp)

Campos, E. \& Wicksten, M. K. (1997). A new genus for the Central American crab Pinnixa costaricana Wicksten, 1982 (Crustacea: Brachyura: Pinnotheridae). Proceedings of the Biological Society of Washington, 110, 69-73. (AC, Bd, CrD, PdC)

Campos, E., Díaz, V. \& Gamboa-Contreras, J. A. (1998) Notes on distribution and taxonomy of five poorly known species of Pinnotherid crabs from the Eastern Pacific (Crustacea: Brachyura: Pinnotheridae). Proceedings of the Biological Society of Washington, 111, 372-381. (AC, Bd, CrD, PdC)

Campos, J. \& Fournier, M. L. (1989). El banco de Ostrea iridescens (Pterioidea: Ostreidae) en Bahía Curú, Costa Rica. Revista de Biología Tropical, 38, 331-333. $(\mathrm{AC}, \mathrm{Eg}, \mathrm{MoB}, \mathrm{Cu})$
Campos, J., Segura, A., Lizano, O. \& Madrigal, E. (1993). Ecología básica de Coryphaena hippurus (Pisces, Coryphaenidae) y abundancia de otros grandes pelágicos en el Pacífico de Costa Rica. Revista de Biología Tropical, 41, 783-790. (AC, Eg, FCG, Pe, PiA)

Carrión-Cortez, J. A. (2010). Área de actividad local, dieta e intensidad de uso del hábitat de forrajeo de la tortuga carey (Eretmochelys imbricata) en el Pacífico norte de Costa Rica. Tesis de Maestría, Posgrado en Ciencias Marinas y Costeras, Universidad Autónoma de Baja California Sur, La Paz, Baja California Sur, México. 84 p. (Eg, PCy, Te, TM)

Carrión-Cortez, J., Canales-Cerro, C., Arauz, R., RisomenaRodríguez, R. (2013). Habitat use and diet of juvenile Eastern Pacific hawkbill turtles (Eretmochelys imbricate) in the North Pacific coast of Costa Rica. Chelonian Conservation and Biology, 12, 235-245. (AC, AMP, Cv, Eg, PCy, TM)

Castaing, A., Jiménez, J. \& Villalobos, C. (1980). Observaciones sobre la ecología de manglares de la costa Pacífica de Costa Rica y su relación con la distribución del molusco Geloina inflata (Phillippi) (Pelecypoda: Corbiculidae). Revista de Biología Tropical, 28, 323-339. (AC, Eg, Mg, MoB, Pt)

Castaing, A., Jiménez, J. M. \& Rojas, J. (1982). Asociación simbiótica entre el cangrejo Pinnotheres sp. indet. (Crustacea, Pinnotheridae) y el molusco Geloina inflata (Phillipi) (Pelecypoda, Corbiculidae), en Costa Rica. Brenesia, 19/20, 553-562. (AC, CrD, $\mathrm{Eg}, \mathrm{Mg}, \mathrm{MoB}, \mathrm{Pt}$ )

Castellanos, I., E. Suárez-Morales \& A. Morales-Ramírez. 2009. Euphausiids. In I. S. Wehrtmann \& J. Cortés (Eds.), Marine Biodiversity of Costa Rica, Central America (Texto: pp. 199-207, Lista de especies: Disco Compacto pp. 164-166). Berlin: Springer. (BC, $\mathrm{Bd}, \mathrm{Cp}, \mathrm{CrE})$

Castellanos, I.A., A. Morales-Ramírez \& E. Suárez-Morales. 2009. Appendicularians (Urochordata). In I. S. Wehrtmann \& J. Cortés (Eds.), Marine Biodiversity of Costa Rica, Central America (Texto: pp. 445-452, Lista de especies: Disco Compacto pp. 411). Berlin: Springer. (Ap, BC, Bd, Cp)

Castro, P. (1996). Eastern Pacific species of Trapezia (Crustacea, Brachyura: Trapeziidae), sibling species symbiotic with reef corals. Bulletin of Marine Science, 58, 531-554. (AC, BC, Bd, CrD, Sy)

Castro-Iglesias, J. C. (1986). Contribución de las tortugas lora solitarias, Lepidochelys olivacea (Eschsholtz) en el mantenimiento de las poblaciones de esta especie. Licenciatura en Biología, Universidad de Costa Rica, San Pedro, Costa Rica. 57 p. (Eg, Os, Te, Tm)

Cate, C. N. (1969). The eastern Pacific cowries. The Veliger, 12, 103-119. (AC, Bd, IM, MoG) 
Cate, C. N. (1979). A review of the Triviidae (Mollusca: Gastropoda). Memoirs of the San Diego Society of Natural History, 10, 126 p. (AC, Bd, MoG, PaN)

Cernohorsky, W. O. (1976). The Mitridae of the world, Part I: The Subfamily Mitrinae. Indo-Pacific Mollusca 3(17), 273-528. (AC, BC, Bd, MoG)

Chaney, H. W. (1987). A comparative study of two similar Panamic cones: Conus ximenes and Conus mahogani. The Veliger, 29, 428-436. (AC, Bd, BS, MoG)

Chang, C. -H., Xie, S. -P., Schneider, N., Qiu, B., Small, J., Zhuang, W., Taguchi, B., Sasaki, H. \& Lin, X. (2012). East Pacific ocean eddies and their relationship to subseasonal variability in Central American wind jets. Journal of Geophysical Research, 117, C10001, doi:10.1029/2011JC007315. (AC, CA, FCG, OF)

Chaves, A., Serrano, G., Marín, G., Arguedas, E., Jiménez, A. \& Spotila, J .R. (1996). Biology and conservation of leatherback turtles, Dermochelys coriacea, at Playa Langosta, Costa Rica. Chelonian Conservervation and Biology, 2, 184-189. (AC, Cv, Eg, PL, TM)

Chavez-Quirós, A. C. 1986. Viabilidad de los huevos de la tortuga marina Lepidochelys olivacea (Eschscholtz) en playa Ostional, Guanacaste, Costa Rica. Licenciatura en Biología, Universidad de Costa Rica, San Pedro, Costa Rica. 51 p. (Arb, Eg, Os, Te, TM)

Chelton, D. B., Freilich, M. H. \& Esbensen, S. N. (2000). Satellite observations of the wind jets off the Pacific coast of Central America. Part I: Case studies and statistical characteristics. Monthly Weather Review, 128, 1993-2018. (AC, CA, GP)

Chelton, D. B., Freilich, M. H. \& Esbensen, S. N. (2000). Satellite observations of the wind jets off the Pacific coast of Central America. Part II: Regional relationships and dynamical considerations. Monthly Weather Review, 128, 2019-2043. (AC, CA, GP)

Chevalier, J., Godfrey, M. H. \& Girondot, M. (1999). Significant difference of temperatura dependent sex determination between French Guiana (Atlantic) and Playa Grande (Costa Rica, Pacific) leatherbacks (Dermochelys coriacea). Annales des sciences naturelles, 20, 147-152. (AC, Eg, PG, TM)

Child, C. A. (1979). Shallow-water Pycnogonida of the Isthmus of Panama and the coast of Middle America. Smithsonian Contributions to Zoology, 293, 1-86. (BC, Bd, BS, Mgr, Pc, PdC)

Clark, H. L. (1940). Eastern Pacific expeditions of the New York Zoological Society. XXI. Notes on Echinoderms from the West Coast of Central America. Zoologica, 25, 331-352. (AC, Bd, B1, BSE, Ec)

Clark, H. L. (1948). A report on the Echini of the warmer eastern Pacific based on the collections of the Velero III. Allan Hancock Pacific Expedetions, 8, 225-352. (AC, BC, Bd, BS, EcE)
Clarke, A. J. (1988). Inertial wind path and sea surface temperature patterns near the Gulf of Tehuantepec and Gulf of Papagayo. Journal of Geophysical Research, 93, 15491-15501. (AC, CA, GP, OF)

Coan, E. V. (1983). The eastern Pacific Donacidae. The Veliger, 25, 273-298. (AC, Bd, MoB, Sr)

Coan, E. V. (1984). The Recent Crassatellinae of the eastern Pacific, with some notes on Crassinella. The Veliger, 26, 153-169. (AC, Bd, BP, MoB)

Coan, E. V. (1988). Recent eastern Pacific species of the bivalve genus Semele. The Veliger, 31, 1-42. (AC, Bd, $\mathrm{Bl}, \mathrm{MoB})$

Coan, E. V. (1990). The Recent eastern Pacific species of the bivalve Family Thraciidae. The Veliger, 33, 20-55. (AC, Bd, B1, MoB)

Coan, E. V. (1990). The eastern Pacific species of the bivalve Family Spheniopsidae. The Veliger, 33, 394-401. (AC, $\mathrm{Bd}, \mathrm{MoB}, \mathrm{PdC})$

Coan, E. V. (2000). The eastern Pacific recent species of the Corbulidae (Bivalvia). Malacologia, 44, 47-105. (AC, $\mathrm{Bd}, \mathrm{BJ}, \mathrm{Bl}, \mathrm{MoB})$

Coan, E. V. (2003). The tropical eastern Pacific species of the Condylocardiidae (Bivalvia). The Nautilus, 117, 47-61. (AC, Bd, B1, BP, BS, CB, MoB)

Coan, E. V., Scott, P. V. \& Bernard, F. (2000). Bivalve Seashells of Western North America. Marine Mollusks from Arctic Alaska to Baja California. Santa Barbara Museum of Natural History, Monograph, 2, 764 p. (BC, Bd, Bl, Mgr, MoB, PSE)

Córdoba-Muñoz, R., Romero-Araya, J. C. \& WindevoxhelLora, N. J. (Compiladores). (1998). Inventario de los humedales de Costa Rica. San José, Costa Rica: UICN, MINAE, SINAC, Embajada Real de los Países Bajos. 380 p. (Hu, Li, Mg, PaN)

Cornelius, S. E. (1975). Marine turtle mortalities along the Pacific coast of Costa Rica. Copeia, 1975, 186-187. (AC, FAN, Na, Pj, PSR, TM)

Cornelius, S. E. (1976). Marine turtle nesting activity at Playa Naranjo, Costa Rica. Brenesia, 8, 1-27. (AC, $\mathrm{Eg}, \mathrm{Pj}, \mathrm{TM})$

Cornelius, S. E. (1982). Status of sea turtles along the Pacific coast of Middle America. In K. Bjorndal (Ed.). Biology and Conservation of Sea Turtles (pp. 211-219). Washington, DC: Smithsonian Institution Press. (Cp, Cv, TM)

Cornelius, S. E. (1986). The Sea Turtles of Santa Rosa National Park. San José, Costa Rica: Fundación de Parques Nacionales. (Bd, Eg, Li, PSR, TM)

Cornelius, S. E. \& Robinson, D. C. (1983). Abundance, distribution, and movements of olive ridley sea turtles in Costa Rica, III. U.S. Fish and Wildlife Service Endangered Species Report 13, Albuquerque, New Mexico, 52 pp. (Eg, Inf, TM) 
Cornelius, S. E. \& Robinson, D. C. (1986). Post-nesting movements of female Olive Ridley turtles tagged in Costa Rica. Vida Silvestre Neotropical, 1, 12-23. (AC, $\mathrm{Bd}, \mathrm{Eg}, \mathrm{Na}, \mathrm{Os}, \mathrm{TM})$

Cornelius, S. E., Alvarado-Ulloa, M., Castro, J. C., Mata del Valle, M. \& Robinson, D. C. (1991). Management of olive ridley sea turtles (Lepidochelys olivacea) nesting at playas Nancite and Ostional, Costa Rica. In J. G. Robinson \& K. H. Redford (Eds.), Neotropical Wildlife Use and Conservation (pp. 111-135). Chicago: University of Chicago Press. (Arb, Bd, Cp, Eg, Na, Os, TM)

Cortés, J. (1996-1997). Comunidades coralinas y arrecifes del Área de Conservación Guanacaste, Costa Rica. Revista de Biología Tropical, 44(3)/45(1), 623-625. (AC, Ar, BSE, Eg, ILC IM)

Cortés, J. (2001). Requiem for an eastern Pacific seagrass bed. Revista de Biología Tropical, 49 (Suplemento 2), 273-278. (AC, BC, Eg, PM)

Cortés, J. (2009). Marine fish parasites. In I. S. Wehrtmann \& J. Cortés (Eds.), Marine Biodiversity of Costa Rica, Central America (Texto: pp. 501-505, Lista de especies: Disco Compacto pp. 493-496). Berlin: Springer. (BC, Bd, Cj, Cp, Ju, Oc)

Cortés, J. (Editor) (2012a). Bahía Culebra, Guanacaste, Pacífico norte de Costa Rica: Investigaciones cientificas en la zona marina y costera / Bahía Culebra, Guanacaste, North Pacific of Costa Rica: Scientific Research of the Marine and Coastal Zone. Revista de Biología Tropical, 60 (Suplemento 2): 244 p. (Al, $\mathrm{BC}, \mathrm{Bd}, \mathrm{CA}, \mathrm{CrD}, \mathrm{EcE}, \mathrm{Eg}, \mathrm{Hi}, \mathrm{Lg}, \mathrm{Mg}, \mathrm{MM}, \mathrm{PlZ}$, $\mathrm{OF}, \mathrm{OQ}, \mathrm{VE})$

Cortés, J. (2012b). Historia de la investigación marina en Bahía Culebra, Guanacaste, Costa Rica. Revista de Biología Tropical, 60 (Suplemento 2), 19-37. (AC, $\mathrm{BC}, \mathrm{Hi})$

Cortés, J. (2012c). Bibliografía anotada sobre organismos, ambientes y procesos marinos en Bahía Culebra, Guanacaste, Costa Rica. Revista de Biología Tropical, 60 (Suplemento 2), 231-242. (BC)

Cortés, J. \& Guzmán, H. M. (1998). Organismos de los arrecifes coralinos de Costa Rica: Descripción, distribución geográfica e historia natural de los corales zooxantelados (Anthozoa: Scleractinia) del Pacífico. Revista de Biología Tropical, 46, 55-92. (AC, BC, Bd, $\mathrm{Bt}, \mathrm{CB}, \mathrm{IM}, \mathrm{PSE}, \mathrm{Sr})$

Cortés, J. \& Jiménez, C. (2003). Corals and coral reefs of the Pacific of Costa Rica: history, research and status. In J. Cortés (Ed.), Latin American Coral Reefs (pp. 361-385). Amsterdam: Elsevier Science. (Ar, BC, $\mathrm{Bd}, \mathrm{Bl}, \mathrm{BSE}, \mathrm{Bt}, \mathrm{CB}, \mathrm{CnA}, \mathrm{Cp}, \mathrm{IM}, \mathrm{IN}, \mathrm{IT}, \mathrm{PSE}, \mathrm{Sr})$

Cortés, J. \& Á. Morales-Ramírez (Editores). 2014. Investigaciones científicas en la zona marino-costera del Pacífico Norte de Costa Rica / Scientific Research of the North Pacific Marine and Coastal Areas of Costa
Rica. Revista de Biología Tropical, 62 (Suplemento 4): $184 \mathrm{p}$.

Cortés, J. \& Murillo, M. M. (1985). Comunidades coralinas y arrecifes del Pacífico de Costa Rica. Revista de Biología Tropical, 33, 197-202. (AC, Ar, BC, Bt, CB, PR, Sr)

Cortés, J. \& Wehrtmann, I. S. (2009). Diversity of marine habitats of the Caribbean and Pacific of Costa Rica. In I. S. Wehrtmann \& J. Cortés (Eds.), Marine Biodiversity of Costa Rica, Central America (pp. 1-45). Berlin: Springer. (Ar, BC, Bd, Bl, BS, BSE, CB, Cj, Cp, ICa, IM, IT, Na, Os, PNB, Po, PSE, Sr, Tr)

Cortés, J., Murillo, M. M., Guzmán, H. M. \& Acuña, J. (1984). Pérdida de zooxantelas y muerte de corales y otros organismos arrecifales en el Caribe y Pacífico de Costa Rica. Revista de Biología Tropical, 32, 227 231. (AC, Ar, BC, CnA, Eg, Ml, Oc, Sr, Sy)

Cortés, J., Mora-Baumgartner, C \& Nielsen, V. (2009). Foraminifera. In I. S. Wehrtmann \& J. Cortés (Eds.), Marine Biodiversity of Costa Rica, Central America (Texto: pp. 131-135, Lista de especies: Disco Compacto pp. 79-82). Berlin: Springer. (BC, Bd, BS, BSE, Cp, Fo)

Cortés, J., V. Nielsen \& A. Herrera-Cubilla. 2009. Bryozoans. In I. S. Wehrtmann \& J. Cortés (Eds.), Marine Biodiversity of Costa Rica, Central America (Texto: pp. 413-416, Lista de especies: Disco Compacto pp. 385-388). Berlin: Springer. (BC, Bd, Br, BS, BSE, $\mathrm{Cp}, \mathrm{PdC})$

Cortés, J., Jiménez, C. E., Fonseca, A. C. \& Alvarado, J. J. (2010). Status and conservation of coral reefs in Costa Rica. Revista de Biología Tropical, 58 (Suplemento 1), 33-50. (AC, Ar, BC, Cv, Eg, Mn)

Cortés, J., Vargas-Castillo, R. \& Nivia-Ruiz, J. (2012). Marine biodiversity of Bahía Culebra, Guanacaste, Costa Rica: published records. Revista de Biología Tropical, 60 (Suplemento 2), 39-71. (AC, , BC, Bd)

Crane, J. (1940). Eastern Pacific Expeditions of the New York Zoological Society. XVIII. On the post-embryonic development of Brachyuran crabs of the genus Ocypode. Zoologica, 25, 65-82. (AC, CrD, Eg, Po)

Crane, J. (1941). Eastern Pacific Expeditions of the New York Zoological Society. XXVI. Crabs of the Genus Uca from the west coast of Central America. Zoologica, 26, 145-208. (AC, BC, Bd, Bl, BSE, CrD, Sr)

Crane, J. (1941). Eastern Pacific Expeditions of the New York Zoological Society. XXIX. On the growth and ecology of Brachyuran crabs of the Genus Ocypode. Zoologica, 26, 297-310. (AC, BC, BSE, CrD, Eg, Sr)

Crane, J. (1947). Eastern Pacific Expeditions of the New York Zoological Society. XXXVIII. Intertidal brachygnathous crabs from the west coast of tropical America with special reference to ecology. Zoologica, 32, 69-95. (AC, BC, Bd, BSE Bt, CrD, Eg, Po, Sr) 
Crane, J. (1975). Fiddler Crabs of the World. Ocypodidae: Genus Uca. Princeton, New Jersey: Princeton University Press. 738 p. (Bd, Bg, Bl, BSE, CrD, Li, Sr)

Crastz, F. (1982). Embriological stages of the marine turtle Lepidochelys oilvacea (Eschschltz). Revista de Biología Tropical, 30, 113-120. (AC, Eg, Na, TM)

Crastz-Peters, F. (1981). El desarrollo embrionario de la tortuga marina Lepidochelys olivacea. Tesis de Maestría, Universidad de Costa Rica, San Pedro, Costa Rica. (Eg, Na, Te, TM)

Crim, J. L., Spotilla, J. R., O’Connor, M., Reina, R., Williams, C. J. \& Paladino, F. V. (2002). The leatherback turtle, Dermochelys coriacea, exhibits both polyandry and polygyny. Molecular Ecology, 11, 2097-2106. (AC, Eg, PNB, TM)

Crocker, T. (1933). The Templeton Crocker Expedition of the California Academy of Sciences, 1932, No. 2: Introductory statement. Proceedings of the California Academy of Sciences, $4^{\text {th }}$ Series, 21, 3-9, plus one plate. (AC, BSE, Bt, Ep, IM)

Crouch, R. W. \& Poag, C. W. (1987). Benthic Foraminifera of the Panamanian Province: distribution and origins. Journal of Foraminiferal Research, 17, 153-176. (AC, BC, Bd, BEJ, BSJ, Bt, Cy, Fo, Pen)

Cruz, R. A. \& Sotela, A. (1984). Contribución a la biología de Chiton stockesii (Polyplacophora: Chitonidae) en Punta Pochote, Puntarenas, Costa Rica. Revista de Biología Tropical, 32, 61-68. (AC, Eg, MoP, Pt)

Cushman, J. A. \& McCulloch, I. (1939). A report on some arenaceous Foraminifera. Allan Hancock Pacific Expeditions, 6, 1-113. (AC, BC, Bd, BS, BSE, Fo, PB)

Cushman, J. A. \& McCulloch, I. (1940). Some Nonionidae in the Collections of the Allan Hancock Foundation. Allan Hancock Pacific Expeditions, 6, 145-178. (AC, $\mathrm{BC}, \mathrm{Bd}, \mathrm{BS}, \mathrm{Fo}, \mathrm{PB})$

Cushman, J. A. \& McCulloch, I. (1942). Some Virgulininae in the Collections of the Allan Hancock Foundation. Allan Hancock Pacific Expeditions, 6, 179-230. (AC, BC, Bd, BS, BSE, Fo)

Cushman, J. A. \& McCulloch, I. (1948). The species of Bulimina and related genera in the collections of the Allan Hancock Foundation. Allan Hancock Pacific Expeditions, 6, 231-294. (AC, BC, Bd, Fo, PB)

Cushman, J. A. \& McCulloch, I. (1950). Some Lagenidae in the collections of the Allan Hancock Foundation. Allan Hancock Pacific Expeditions, 6, 295-364. (AC, $\mathrm{Bd}, \mathrm{BS}, \mathrm{Fo}, \mathrm{PB})$

Cutler, N., Cutler, E. \& Vargas, J. A. (1992). Peanut worms (Phylum Sipuncula) from Costa Rica. Revista de Biología Tropical, 40, 153-158. (AC, Bd, Ml, PCh, $\mathrm{Si}, \mathrm{Sr}, \mathrm{Tr}$ )

D'Attilio, A. (1987). Typhisopsis coronatus and dwarf Typhisala grandis at Costa Rica. The Festivus, 19, 32-35. (AC, Bd, MoG, PdC)
D’Attilio, A. \& Myers, B. W. (1987). Emended description and designation of lectotypes for Favartia (Murexiella) humilis (Broderip, 1833) and F. (M.) norrisii (Reeve, 1845 ) and discussion of $F$. (M.) laurae (E.H. Vokes, 1970): Muricidae. The Festivus, 19, 2-8. (AC, Bd, MoG, PdC)

Dawson, E. Y. (1949). Studies of northeast Pacific Gracilariaceae. Allan Hancock Foundation Publications: Occasional Papers, 7, 1-104. (Al, Bd, BSE, Mgr)

Dawson, E. Y. (1957). Marine algae from the Pacific Costa Rican gulfs. Los Angeles County Museum, Contributions in Science, 15, 1-28. (AC, Al, BC, Bd, BS, BSE)

Dawson, E. Y. (1960). New records of marine algae from Pacific Mexico and Central America. Pacific Naturalist 1(20), 31-52. (AC, Al, BC, Bd, Bl, BS, Po)

Dawson, E. Y. (1961). A guide to the literature and distributions of Pacific benthic algae from Alaska to the Galapagos Islands. Pacific Science, 15, 370-461. (AC, $\mathrm{Al}, \mathrm{BC}, \mathrm{Bd}, \mathrm{BSE}, \mathrm{Po})$

Dawson, E. Y. \& Beaudette, P. T. (1959). Field notes from the 1959 eastern Pacific cruise of the Stella Polaris. Pacific Naturalist, 1 (13), 1-24. (AC, Al, BC, Bd, Bl, BS, Ep, Po)

Dean, H. K. (2001). Marine Biodiversity of Costa Rica: The phyla Sipuncula and Echiura. Revista de Biología Tropical, 49 (Suplemento 2), 85-90. (AC, Bd, Cu, IM, Ml, PCh, Py, Sr, Tr)

Dean, H. K. (2004). Marine biodiversity of Costa Rica: Class Polychaeta (Annelida). Revista de Biología Tropical, 52 (Suplemento 2), 131-181. (AC, BC, Bd, BS, BSE, CB, Cl, Cu, PF, IM, Ml, Mt, PCh, PB, PGi, PIs, Py, Sr, Tr)

Deichmann, E. (1938). Eastern Pacific Expeditions of the New York Zoological Society. XVI. Holothurians from the western coast of Lower California and Central America, and from the Galapagos Islands. Zoologica, 23, 361-387. (AC, Bd, B1, BSE, EcH)

Deichmann, E. (1941). The Holothurioidea collected by the Velero III during the years 1932 to 1938. Part I. Dendrochirota. Allan Hancock Pacific Expeditions, 8(3), 61-195. (AC, Bd, BSE, EcH, PB)

Deichmann, E. (1958). The Holothurioidea collected by the Velero III and IV during the years 1932 to 1954. Part II. Aspidochirota. Allan Hancock Pacific Expeditions, 11(2), 253-349. (AC, BC, Bd, BS, BSE, EcH, PB)

Dexter, D. M. (1974). Sandy-beach fauna of the Pacific and Atlantic coasts of Costa Rica and Colombia. Revista de Biología Tropical, 22, 51-66. (AC, Bd, CrI, Eg, PdC, Py, Sr, Tr)

Dominici-Arosemena, A. (1999). Estructura poblacional de los peces de arrecifes del Golfo de Papagayo, Guanacaste, Costa Rica, con énfasis en las especies de mayor importancia comercial como ornamentales. 
Tesis de Maestría en Biología, Universidad de Costa Rica. San Pedro, Costa Rica. 208 p. (BC, Eg, Pe, Te)

Dominici-Arosemena, A., Brugnoli-Olivera, E., CortésNúñez, J., Molina-Ureña, H. \& Quesada-Alpízar, M. (2005). Community structure of eastern Pacific reef fishes (Gulf of Papagayo, Costa Rica). Tecnociencia, 7(2), 19-41. (AC, BC, Eg, Pe)

Downey, M. E. (1969). Catalog of Recent Ophiuroid Type specimens in major collections in the United States. United States National Museum, Bulletin, 293, 1-239. (AC, Bd, Bl, BS, EcO)

Drake, D. L. \& Spotila, J. R. (2002). Thermal tolerances and the timing of sea turtle hatchling emergence. Journal of Thermal Biology, 27, 71-81. (AC, Eg, PG, TM)

Drake, D. L., Behm, J., Hagerty, M.A., Mayor, P. A., Goldenberg, S. \& Spotila, J. R. (2003). Marine turtle nesting activity at Playa Naranjo, Santa Rosa National Park, Costa Rica, for the 1998-1999 season. Chelonian Conservation and Biology, 4, 675-678. (AC, Eg, Pj, $\mathrm{TM})$

Draper, B. C. (1974). Minute shells - part 9. The Tabulata, 7, 100-114. (AC, MoG, PaN)

Drouet, F. (1936). Myxophyceae of the G. Allan Hancock Expedition of 1934, collected by Wm. R. Taylor. Allan Hancock Pacific Expeditions, 3, 15-32. (AC, $\mathrm{BC}, \mathrm{Bd}, \mathrm{Ci})$

Duchene, S., Frey, A., Alfaro-Núñez, A., Dutton, P. H., Gilbert, M. P. T., \& Morin, P. A. (2012). Marine turtle mitogenome phylogenetics and evolution. Molecular Phylogenetics and Evolution, 65, 241-250. (AC, Fg, Gn, Os, TM)

Durham, J. W. \& Barnard, J. L. (1952). Stony corals of the Eastern Pacific collected by the Velero III and the Velero IV. Allan Hancock Pacific Expeditions, 16, 1-110. (AC, BC, Bd, CaN, PB

Dushane, H. \& Draper, B. C. (1975). The genus Seila in the eastern Pacific (Mollusca: Gastropoda). The Veliger, 17, 335-345. (AC, Bd, MoG, PSE)

Echeverría-Sáenz, S. \& Wehrtmann, I. S. (2011). Egg production of the commercially exploited deepwater shrimp, Heterocarpus vicarius (Decapoda: Pandalidae), Pacific Costa Rica. Journal of Crustacean Biology, 31, 434-440. (AC, CrD, FCG, GP, Pe, ZP)

Eckrich, C. E. \& Owens, D. W. (1995). Solitary versus Arribada nesting in the Olive Ridley sea turtles (Lepidochelys olivacea): a test of the predator-satiation hypothesis. Herpetologica, 51, 349-353. (AC, Arb, Eg, Na, TM)

Efford, I. E. (1976). Distribution of the sand crabs in the genus Emerita (Decapoda, Hippidae). Crustaceana, 30, 169-183. (AC, Bg, CrD, PdC)

Ellison, A. M. (2004). Wetlands of Central America. Wetlands Ecology and Management, 12, 3-55. (AC, BS, $\mathrm{Mg}$, PSR, Tr)
Emerson, W. K. (1965). The eastern Pacific species of Niso (Mollusca: Gastropoda). American Museum Novitates, 2218, 1-12. (AC, Bd, BSE, MoG)

Emerson, W. K. (1991). First records for Cymatium mundum (Gould) in the eastern Pacific Ocean, with commments on the zoogeography of the tropical trans-Pacific Tonnacean and non-Tonnacean prosobranch gastropods with Indo-Pacific faunal affinities in the west American waters. The Nautilus, 105, 62-80. (AC, BC, Bd, Bg, $\mathrm{BS}, \mathrm{MoG}, \mathrm{PdC})$

Enfield, D. \& Alfaro, E.J. (1999). The dependence of Caribbean rainfall on the interaction of the tropical Atlantic and Pacific oceans. Journal of Climate, 12, 2093-2103. (AC, CA)

Espinoza, M. \& Salas, E. (2005). Estructura de las comunidades de peces de arrecifes en las Islas Catalinas y Playa Ocotal, Pacífico Norte de Costa Rica. Revista de Biología Tropical, 53, 523-536. (AC, Eg, ICa, Oc, PiE)

Espinoza, M., Clarke, T. M., Villalobos-Rojas, F. \& Wehrtmann, I. S. (2012). Ontogenetic dietary shifts and feeding ecology of the rasptail skate Raja velezi and the brown smoothhound shark Mustelus henlei along the Pacific coast of Costa Rica, Central America. Journal of Fish Biology, 81, 1578-1595. (AC, Eg, FCG, PiE)

Espinoza, M., Clarke, T. M., Villalobos-Rojas, F. \& Wehrtmann, I. S. (2013). Diet composition and diel feeding behaviour of the banded guitarfish Zapteryx xyster along the Pacific coast of Costa Rica, Central America. Journal of Fish Biology, 82, 286-305. (AC, Eg, FCG, PiE)

Excoffon, A.C., Acuña, F. H. \& Cortés, J. (2009). The sea anemone Nemanthus californicus (Cnidaria, Actiniaria, Nemanthidae) from Costa Rica: re-description and first record outside the type locality. Marine Biodiversity Records, MBAUK 2, 1-5. (AC, Bd, CnA, IM)

Fauchald, K. (1973). Polychaetes from Central American sandy beaches. Bulletin of the Southern California Academy of Sciences, 72, 19-31. (AC, Bd, PdC, Py, $\mathrm{Sr}, \mathrm{Tr}$ )

Fernández A., M. (2002). Daños, efectos y amenaza de tsunamis en América Central. Revista Geológica de América Central, 26, 71-83. (AC, OF, Ts)

Fernández-Arce, M. \& Alvarado-Delgado, G. (2004). Vulnerabilidad y capacitación comunitaria ante tsunamis en Costa Rica. Revista Reflexiones, 83(2): 51-60. (AC, OF, Ts)

Fernández-Arce, M. \& Alvarado-Delgado, G. (2005). Tsunamis and tsunami prepardness in Costa Rica, Central America. ISET Journal of Earthquake Technology, 42(4), 203-212. (AC, Ts)

Fernández-Arce, M., G. Peraldo, R. Flores \& W. Rojas, 1993. Tsunamis en Centroamérica. Tecnología en 
Marcha, 12(2), 17-30. (AC, BC, BP, BS, Bt, Cj, JuN, Pam, PdC, , Ts)

Fernández, C. \& Alvarado, J. J. (2008). Chlorophyta de la costa Pacífica de Costa Rica. Revista de Biología Tropical, 56 (Suplemento 4), 149-162. (AC, Al, Bg, PaN)

Fernández, C. \& Cortés, J. (2005). Reef Site: Caulerpa sertularioides, a green alga spreading aggressively over coral reef communities in Culebra Bay, North Pacific of Costa Rica. Coral Reefs, 24, 10. (AC, Al, BC, Eg)

Fernández-García, C. (2007). Propagación del alga Caulerpa sertularioides (Chlorophyta) en Bahía Culebra, Golfo de Papagayo, Pacífico norte de Costa Rica. Tesis de Maestría, Universidad de Costa Rica. San Pedro, Costa Rica. 92 p. (Al, BC, Eg, Te)

Fernández-García, C. 2012. Taxonomía y biogeografía de las familias Caulerpaceae (Chlorophyta), Dictyotaceae (Ochrophyta), Corallinaceae (Rhodophyta) en el Pacífico de Centroamérica. Disertación de Doctorado, Universidad Autónoma de Baja California Sur, La Paz, México. 253 p. (Al, BC, Bd, Bg, BS, IB, IN, IV, PNB, Te)

Fernández-García, C., Cortés, J., Alvarado, J. J. \& NiviaRuiz, J. (2012). Physical factors contributing to the benthic dominance of the alga Caulerpa sertularioides (Caulerpaceae, Chlorophyta) in the upwelling Bahía Culebra, north Pacific of Costa Rica. Revista de Biología Tropical, 60 (Suplemento 2), 93-107. (AC, Al, BC, Eg)

Ferreira, A. J. (1983). The genus Chaetopleura Shuttleworth, 1853 (Mollusca: Polyplacophora) in the warm-temperate and tropical eastern Pacific, southern California to Perú, with the description of two new species. The Veliger, 25, 203-224. (AC, Bd, B1, BS, MoP, PdC)

Fiedler, P. C. (2002). The annual cycle and biological effects of the Costa Rica Dome. Deep-Sea Research I, 49, 321-338. (AC, DCR, GP, OF)

Fischer, R. (1978). Pared seudoaglutinada en una perforación de Lithophaga (Rupiphaga) hastasia Olsson (Bivalvia). Brenesia, 14/15, 259-266. (AC, Bi, Eg, $\mathrm{MoB}, \mathrm{Tr})$

Fischer, R. (1980). Bioerosion durch Gelege von Nerita funiculata and Nerita scabricosta (Gastropoda). Neues Jahrbuch für Geologie und Paläontologie, 5, 287-292. (AC, Bi, Eg, MoG, Pn)

Fischer, R. (1981). Bioerosion of basalt of the Pacific coast of Costa Rica. Senckenbergiana Maritima, 13, 1-41. (AC, Bi, CrD, EcE, Eg, MoB, MoG, PaN)

Fischer, R. (1990). Biogenetic and non biogenetic determined morphologies of the Costa Rican Pacific coast. Zeitschrift für Geomorphologie, Neue Folge, 34, 313321. (AC, Bi, CrD, EcE, Eg, Go, MoB, MoG, PaN)

Fischer, R. \& Meyer, W. (1985). Observations on rock boring by Alpheus saxidomus (Crustacea: Alpheidae). Marine Biology, 89, 213-219. (AC, Bi, CrD, Eg, PaN)
Fonseca, L. G., Murillo, G. A., Guadamúz, L., Spínola, R. M. \& Valverde R. A. (2009). Downward but stable trend in the abundance of arribada olive ridley sea turtles (Lepidochelys olivacea) at Nancite Beach, Costa Rica (1971-2007). Chelonian Conservation and Biology, 8, 19-27. (AC, Arb, Cv, Eg, Na, TM)

Foster, J. M., LeCroy, S. E., Heard, R. W. \& Vargas, R. (2009). Gammaridean amphipods. In I. S. Wehrtmann \& J. Cortés (Eds.), Marine Biodiversity of Costa Rica, Central America (Texto: pp. 265-274, Lista de especies: Disco Compacto pp. 212-216.). Berlin: Springer. (Bd, Cp, CrA, IM)

Fournier, M. L. (1992). The reproductive biology of the tropical rocky oyster Ostrea iridescens (Bivalvia: Ostreidae) on the Pacific coast of Costa Rica. Aquaculture, 101, 371-378. (AC, Cu, Eg, MoB)

Fradin, E. (1892). Estudios del Golfo de Nicoya, de la Bahía de Cocos y del Golfo de Culebra. San José: Tipografía Nacional, pp. 97-106. (Re-impreso en Carlos Meléndez Ch. 1974. Viajes por Guanacaste. NOS VEN, 4, 273-290). (AC, BC, Hi, PdC)

Franco-Mata, E. 1999. Turismo en manglares de Costa Rica: una alternativa para mejorar: In T. Ammour, A. Imbach, D. Suman \& N. Windevoxhel (Eds.), Manejo productivo de manglares en América Central (pp. 159-169). Serie Técnica No. 7. Turrialba, Costa Rica: CATIE. (Cp, Ma, Mg, Tr, Tu)

Fraser, C. M. (1938). Hydroids of the 1934 Hancock Pacific Expeditions. Allan Hancock Pacific Expeditions, 4, 1-105. (AC, BC, Bd, CnH)

Fraser, C. M. (1938). Hydroids of the 1932, 1933, 1935, and 1938 Allan Hancock Pacific Expeditions. Allan Hancock Pacific Expeditions, 4, 129-153. (AC, Bd, BS, BSE, CnH, PB, PSE)

Fraser, C. M. (1943a). General account of the scientific work of the Velero III in the eastern Pacific, 19311941, Part II: Geographic and biological associations. Allan Hancock Pacific Expeditions, 1(2), 49-258. (AC, BC, BS, BSE, CnH, Ep, PB, PSE)

Fraser, C. M. (1943b). General account of the scientific work of the Velero III in the eastern Pacific, 1931-1941, Part III: a ten-year list of the Velero III collecting stations (Charts 1-115). With an appendix of collecting stations of the Allan Hancock Foundation for the year 1942. Allan Hancock Pacific Expeditions, 1(3), 259-431. (AC, BC, BS, BSE, CnH, Ep, PB, PSE)

Fraser, C. M. (1948). Hydroids of the Allan Hancock Pacific Expeditions since March, 1938. Allan Hancock Pacific Expeditions, 4(5), 179-335. (AC, BC, Bd, BSE, CnH, PB, PSE)

Fritzsche, R. A. 1980. Revision of the Eastern Pacific Syngnathidae (Pisce, Sisyngnathiformes), including both Recent and fossil forms. Proceedings of the California Academy of Sciences, 42, 181-227. (AC, BC, Bd, IM, PiA) 
Fujino, T. (1972). A new Pontoniinid shrimp, Pontonia spighti sp. nov., associated with a newly described ascidian from the Pacific coast of Costa Rica (Decapoda, Natantia, Pontoniinae). Publication of the Seto Marine Biological Laboratory, 19, 293-301. (AC, Bd, $\mathrm{CrD}, \mathrm{PdC}, \mathrm{Tn})$

García, V., Acuña-González, J., Vargas-Zamora, J. A. \& García-Céspedes, J. (2006). Calidad bacteriológica y desechos sólidos en cinco ambientes costeros de Costa Rica. Revista de Biología Tropical, 54 (Suplemento 1), 35-48. (AC, BC, CtB, CtS)

García-Céspedes, J., Acuña-González, J. A. \& VargasZamora, J. A. (2004). Metales traza en sedimentos de cuatro ambientes costeros de Costa Rica. Revista de Biología Tropical, 52 (Suplemento 2), 51-60. (AC, $\mathrm{BC}, \mathrm{CtM})$

Garth, J. S. (1940). Some new species of Brachyuran crabs from Mexico and the Central and South American mainland. Allan Hancock Pacific Expeditions, 5(3), 53-127. (AC, BC, Bd, BS, BSE, CrD, PB)

Garth, J. S. (1958). Brachyura of the Pacific coast of America. Oxyrhyncha. Tables and Plates. Allan Hancock Pacific Expeditions, 21(2), 501-854. (AC, BC, Bd, BS, BSE, CrD, PB, PdC)

Garth, J. S. (1959). Eastern Pacific Expeditions of the New York Zoological Society. XLIV. Non-intertidial brachygnathous crabs from the west coast of Tropical America. Part 1: Brachygnatha, Oxyrhyncha. Zoologica, 44, 105-126. (AC, BC, Bd, B1, BSE, CrD, Sr)

Garth, J. S. (1961). Eastern Pacific Expeditions of the New York Zoological Society. XLV. Non-intertidial brachygnathous crabs from the west coast of Tropical America. Part 2: Brachygnatha Brachyrhyncha. Zoologica, 46, 133-160. (AC, BC, Bd, B1, BSE, CrD, Sr)

Garth, J. S. (1966). Eastern Pacific Expeditions of the New York Zoological Society. XLVI. Oxystomatous and allied crabs from the west coast of Tropical America. Zoologica, 51, 1-16. (AC, BC, Bd, B1, BSE, CrD, IM, Sr)

Garth, J. S. (1974). On the ocurrence in the eastern tropical Pacific of Indo-West Pacific decapod crustaceans commensal with reef-building corals. Proceedings of the $2^{\text {nd }}$ International Coral Reef Symposium, Brisbane, 1, 397-404. (Bg, BSE, CnA, CrD, Sm, Sy)

Gateño, D., León, A., Barki, Y., Cortés, J. \& Rinkevich, B. (2003). Skeletal tumor formations in the massive coral Pavona clavus. Marine Ecology Progress Series, 258, 97-108. (AC, BC, CnA, Eg, En)

Gates, C. E., Valverde, R. A., Mo, C. L., Chaves, A. C., Ballesteros, J. \& Pesk, J. (1996). Estimating Arribada size using a modified instantaneous count procedure. Journal of Agricultural, Biological, and Environmental Statistics, 1, 275-287. (AC, Arb, Eg, Na, TM)
Glynn, P. W. (1999). Pocillopora inflata, a new species of scleractinian coral (Cnidaria: Anthozoa) from the tropical eastern Pacific. Pacific Science, 53, 168-180. (AC, Bd, CnA, IM)

Glynn, P. W., Druffel, E. M. \& Dunbar, R. B. (1983). A dead Central American coral reef tract: possible link with the Little Ice Age. Journal of Marine Research, 41, 605-637. (AC, BC, Eg, CnA, PEH)

Goldberg, S. R. (2004). Note on reproduction of the yellowbelly sea snake, Pelamis platurus (Serpentes: Elapidae) from Costa Rica. Bulletin of the Maryland Herpetological Society, 40, 91-93. (AC, Eg, FCG, Rp)

Gonzalez-Silvera, A., Santamaria-del-Angel, E., MillánNuñez, R. \& Manzo-Monroy, H. (2004). Satellite observations of mesoscale eddies in the Gulfs of Tehuantepec and Papagayo (Eastern Tropical Pacific). Deep-Sea Research II, 51, 587-600. (AC, GP, OF)

Gore, R. H. (1982). Porcellanid crabs from the coasts of Mexico and Central America (Crustacea: Decapoda: Anomura). Smithsonian Contributions to Zoology, 363, 1-34. (AC, Bd, CrD, PdC)

Gore R. H. \& Abele, L. G. (1973). Three new species of porcellanid crabs (Crustacea, Decapoda, Porcellanidae) from the Bay of Panama and adjacent Caribbean waters. Bulletin of Marine Science, 23, 559-573. (AC, $\mathrm{Bd}, \mathrm{BS}, \mathrm{CrD}, \mathrm{PB})$

Grau, G. 1959. Pectinidae of the eastern Pacific. Allan Hancock Pacific Expeditions, 23: I-VII, 1-308. (AC, BC, $\mathrm{Bd}, \mathrm{MoB}, \mathrm{PdC})$

Gravel, P., Johanning, K., McLachlan, J., Vargas, J. A. \& Oberdörster, E. (2006). Imposex in the intertidal snail Thais brevidentata (Gastropoda: Muricidae) from the Pacific coast of Costa Rica. Revista de Biología Tropical, 54 (Suplemento 1), 21-26. (AC, BC, Is, MoG)

Grove, J. S. \& Lavenberg, R. J. (1997). The Fishes of the Galápagos Islands. Stanford, California: Stanford University Press. 863 p. (Bd, IM, Li, PiA)

Gutiérrez-Echeverria, A. \& Soley A., F. A. (1988). Características del nivel del mar en los litorales costarricenses. Ciencia y Tecnología, 12(1-2), 117-131. (AC, GP, OF)

Hahn, A. T. (2011). Filogeografia global da tartaruga oliva (Lepidochelys olivacea). Disertación doctoral, Faculdade de Biociências, Pontifícia Universidade Católica do Rio Grande do Sul, Porto Alegre, Rio Grande do Sul, Brasil. 107 p. (Fg, Gn, Na, Te, TM)

Haig, J. (1960). The Porcellanidae (Crustacea: Anomura) of the eastern Pacific. Allan Hancock Pacific Expeditions, 24, 1-440. (AC, BC, Bd, Bl, BS, BSE, CrD, PB, PdC)

Haig, J. (1968). Eastern Pacific expeditions of the New York Zoological Society. Porcellanid crabs (Crustacea: Anomura) from the west coast of Tropical America. Zoologica, 53, 57-74. (AC, BC, Bd, B1, BSE, CrD)

Hanna, G. D. \& Strong, A. M. (1949). West American mollusks of the genus Conus. Proceedings of the 
California Academy of Sciences, $4^{\text {th }}$ Series, 26, 247322. (AC, BC, Bd, Bl, BSE, Bt, IM, MoG, PB, PdC, $\mathrm{Sr})$

Hartman, O. (1939). Polychaetous Annelids. Part I. Aphroditidae to Pisionidae. Allan Hancock Pacific Expeditions, 7(1), 1-155. (AC, Bd, BSE, PB, PdC, Py)

Hartman, O. (1940). Polychaetous Annelids. Part II. Chrysopetalidae to Goniadidae. Allan Hancock Pacific Expeditions, 7, 173-287. (AC, BC, Bd, BS, BSE, PB, Py)

Hartman, O. (1944). Polychaetous annelids. Pt. V. Eunicea. Allan Hancock Pacific Expeditions, 10, 1-238. (AC, $\mathrm{BC}, \mathrm{Bd}, \mathrm{GP}, \mathrm{Py})$

Hartman, O. (1944). Polychaetous annelids. Pt. VI. Paraonidae, Magelonidae, Longosomidae, Ctenodrilidae and Sabellariidae. Allan Hancock Pacific Expeditions, 10, 311-389. (AC, BC, Bd, GP, PB, Py)

Harvey, A. W. \& McLaughlin, P. (1991). Two new hermit crabs of the genus Pagurus (Provenzanoi group) (Crustacea, Anomura, Paguridae) from the eastern Pacific, with notes on their ecology. Natural History Museum of Los Angeles County, Contributions in Science, 425, 13-21. (AC, Bd, BSE, CrD)

Heard, R. W., Breedy, O. \& Vargas, R. (2009). Tanaidaceans. In I. S. Wehrtmann \& J. Cortés (Eds.), Marine Biodiversity of Costa Rica, Central America (Texto: pp. 245-256, Lista de especies: Disco Compacto pp. 204-205). Berlin: Springer. (Bd, Cp, CrT, IM)

Heidemeyer, M., Arauz-Vargas, R. \& López-Agüero, E. New foraging grounds for hawksbill (Eretmochelys imbricata) and green turtles (Chelonia mydas) along the northern Pacific coast of Costa Rica, Central America. Revista de Biología Tropical, 62 (Suplemento 4), 109-118. (AC, BMt. CB, Eg, PdC, PR, TM)

Hendrickx, M. E. \& Harvey, A. W. (1999). Checklist of anomuran crabs (Crustacea: Decapoda) from the eastern tropical Pacific. Belgium Journal of Zoology, 129, 363-389. (AC, Bd, BS, BSE, CrD)

Hendrickx, M. E. \& Wicksten, M. K. (1989). Los Pandalidae (Crustacea: Caridea) del Pacífico mexicano, con una clave para su identificación. Caldasia, 16, 71-86. (AC, $\mathrm{BC}, \mathrm{Bd}, \mathrm{CB}, \mathrm{CrD})$

Henry, D. P. \& McLaughlin, P. A. (1967). A revision of the subgenus Solidabalanus Hoek (Cirripedia, Thoracica) including a description of a new species with complemental males. Crustaceana, 12, 43-58. (AC, $\mathrm{BC}, \mathrm{Bd}, \mathrm{CrP})$

Henry, D. P. \& McLaughlin, P. A. (1975). The barnacles of the Balanus amphitrite complex (Cirripedia, Thoracica). Zoologische Verhandelingen, 141, 1-254. (AC, $\mathrm{BC}, \mathrm{Bd}, \mathrm{BS}, \mathrm{CrP})$

Hernáez, P. \& Vargas, R. (2013). A new species of Callianidea H. Milne Edwards, 1837 (Decapoda, Axiidea, Callianideidae) from the Pacific coast of Central
America, with key to the genus. Zootaxa, 3681, 147154. (AC, Bd, CrD, IM, PG)

Hernáez, P. \& Wehrtmann, I. S. (2011). Sexual maturity and egg production in an unexploited population of the red squat lobster Pleuroncodes monodon (Decapoda, Galatheidae) from Central America. Fishery Research, 107, 276-282. (AC, CrD, Eg, FCG, GP, Pe)

Hernáez, P., Clarke, T. M., Benavides-Varela, C., VillalobosRojas, F., Nivia-Ruiz, J. \& Wehrtmann, I. S. (2011). Population demography and spatial distribution of the mantis shrimp Squilla biformes (Stomatopoda, Squillidae) from Pacific Costa Rica. Marine Ecology Progress Series, 424, 157-168. (AC, CrD, Eg, FCG, GP)

Hernández-Sánchez, R. A. (2011). Evaluación de la importancia ecológica de la tortuga lora (Lepidochelys olivacea) (Eschscholtz 1829) en el aporte de energía durante eventos de arribadas en Playa Ostional, Guanacaste. Maestría en Ciencias Marinas y Costeras, Universidad Nacional. (Arb, Eg, Os, Te, TM)

Hertlein, L. G. (1935). The Templeton Crocker Expedition of the California Academy of Sciences, 1932. No. 25: The Recent Pectinidae. Proceedings of the California Academy of Sciences, 4th series, 21, 301-328. (AC, $\mathrm{Bd}, \mathrm{BSE}, \mathrm{Bt}, \mathrm{IM}, \mathrm{MoB})$

Hertlein, L. G. \& Strong, A. M. (1940). Eastern Pacific Expeditions of the New York Zoological Society. XXII. Mollusks from the West Coast of Mexico and Central America. Part I. Zoologica, 25, 369-430. (AC, Bd, Bl, CB, MoB)

Hertlein, L. G. \& Strong, A. M. (1943). Eastern Pacific Expeditions of the New York Zoological Society. XXXII. Mollusks from the West Coast of Mexico and Central America. Part II. Zoologica, 28, 149-168. (AC, BC, Bd, Bl, BSE, MoB, Po, Sr)

Hertlein, L. G. \& Strong, A. M. (1946). Eastern Pacific Expeditions of the New York Zoological Society. XXXIV. Mollusks from the West Coast of Mexico and Central America. Part III. Zoologica, 31: 53-76. (AC, BC, Bd, Bl, BSE, MoB, Sr)

Hertlein, L. G. \& Strong, A. M. (1946). Eastern Pacific Expeditions of the New York Zoological Society. XXXV. Mollusks from the West Coast of Mexico and Central America. Part IV. Zoologica, 31: 93-120. (AC, BC, Bd, BSE, MoB, Sr)

Hertlein, L. G. \& Strong, A. M. (1947). Eastern Pacific Expeditions of the New York Zoological Society. XXXVI. Mollusks from the West Coast of Mexico and Central America. Part V. Zoologica, 31, 129-150. (AC, BC, Bd, Bl, BSE, MoB)

Hertlein, L. G. \& Strong, A. M (1948). Eastern Pacific Expeditions of the New York Zoological Society. XXXIX. Mollusks from the West Coast of Mexico and Central America. Part VI. Zoologica, 33, 163198. (AC, BC, Bd, Bl, BSE, MoB, Po, Sr) 
Hertlein, L. G. \& Strong, A. M. (1949). Eastern Pacific Expeditions of the New York Zoological Society. XL. Mollusks from the West Coast of Mexico and Central America. Part VII. Zoologica, 34, 63-97. (AC, BC, $\mathrm{Bd}, \mathrm{Bl}, \mathrm{BSE}, \mathrm{MoB})$

Hertlein, L. G. \& Strong, A. M. 1949. Eastern Pacific Expeditions of the New York Zoological Society. XLI. Mollusks from the West Coast of Mexico and Central America. Part VIII. Zoologica, 34, 239-258. (AC, BC, Bd, BSE, MoB)

Hertlein, L. G. \& Strong, A. M. 1950. Eastern Pacific Expeditions of the New York Zoological Society. XLII. Mollusks from the West Coast of Mexico and Central America. Part IX. Zoologica, 35, 217-252. (AC, BC, BSE, B1, MoB, Sr)

Hertlein, L. G. \& Strong, A. M. 1951. Eastern Pacific Expeditions of the New York Zoological Society. XLIII. Mollusks from the West Coast of Mexico and Central America. Part X. Zoologica, 36, 66-120. (AC, $\mathrm{BC}, \mathrm{Bd}, \mathrm{Bl}, \mathrm{BSE}, \mathrm{MoB}, \mathrm{Sr}$ )

Hertz, C. M., Myers, B. W. \& Gemmell, J. 1992. Two new vitrinellid species from the Gulf of California, Mexico (Gastropoda: Vitrinellidae). The Veliger, 35, 70-73. (AC, BC, Bd, MoG)

Hidalgo, H. \& Alfaro, E. J. (2012). Global Model selection for evaluation of climate change projections in the Eastern Tropical Pacific Seascape. Reista de. Biología. Tropical, 60 (Supl. 3), 67-81. (AC, CA)

Hoberg, E. P., Brooks, D. R., Molina-Ureña, H. \& Erbe, E. (1998). Echinocephalus janzeni n.sp. (Nematoda: Gnathostomatidae) in Himantura pacifica (Chondrichthyes: Myliobatiformes) from the Pacific coast of Costa Rica and Mexico, with historial biogeographic analysis of the genus. Journal of Parasitology, 84, 571-581. (AC, BC, Bd, Ne, PiE)

Hodkinson, I. D. (1992). Telmasylla gen. n., an unusual psyllid from black mangrove in Florida and Costa Rica (Insecta, Homoptera, Psylloidea). Zoologica Scripta, 21, 307-309. (AC, Bd, IMa, Mg, Pj)

Holthuis, L. B. (1952). A general revision of the Palaemonidae (Crustacea: Decapoda: Natantia) of the Americas. II. The subfamily Palaemoninae. Allan Hancock Foundation Publication: Occasional Papers, 12, 1-396. (Bd, BSE, CrD, Mgr, PB)

Holthuis, L .B. (1980). Alpheus saxidomus new species, a rock boring snapping shrimp from the Pacific coast of Costa Rica, with notes on Alpheus simus Guérin-Méneville, 1856. Zoologische Mededelingen, 55, 47-58. (AC, Bd, Bi, CrD, Tr)

Hope, R. A. (2000). Egg harvesting of the olive ridley marine turtle (Lepidochelys olivacea) along the Pacific coast of Nicaragua and Costa Rica: an arribada sustainability analysis. M.A. thesis, Institute for Development Policy and Management, University of Manchester, U.K. (Arb, Cv, Gua, Te, TM)
Hope, R. A. (2002). Wildlife harvesting, conservation and poverty: the economics of olive ridley egg exploitation. Environmental Conservation, 29, 375-384. (AC, Cv, Gua, TM)

Honarvar, S., O’Connor, M.P. \& Spotila, J.R. (2008). Density-dependent effects on hatching success of the olive ridley turtle, Lepidochelys olivacea. Oecologia, 157, 221-230. (AC, Arb, Eg, Na, TM)

Houart, R. \& Hertz, C. M. (2006). A review of Typhisopsis jousseaume, 1880, and Typhisala jousseaume, 1881 (Gastropoda: Muricoidea) of the eastern Pacific. The Nautilus, 120, 52-65. (AC, Bd, MoG, PdC)

Houbrick, J. R. (1968). New record of Conus ebraeus in Costa Rica. The Veliger, 10, 292. (AC, Bd, MoG, PdC)

Hughes, D. A. \& Richard, J. D. (1974). The nesting of the Pacific ridley Lepidochelys olivacea on Playa Nancite, Costa Rica. Marine Biology, 24, 97-107. (AC, Arb, Eg, Na, TM)

Hulin, V., Delmas, V., Girondot, M., Godfrey, M. H. \& Guillon, J.-M. (2009). Temperature-dependent sex determination and global change: are some species at greater risk? Oecologia, 160, 493-506. (AC, Eg, PG, TM)

Ibarra-Gene, E. 1996. El valor de uso del paisaje submarino en el Golfo de Papagayo: comparación de la industria de buceo deportivo con la industria de extracción de peces de acuario. Licenciatura Economía, Universidad de Costa Rica. San Pedro, Costa Rica. 155 p. (BC, $\mathrm{PdC}, \mathrm{SE}, \mathrm{Te})$

Iwamoto, T. (1979). Eastern Pacific macrourine grenadiers with seven branchiostegal rays (Pisces: Macrouridae). Proceedings of the California Academy of Sciences, 42, 135-179. (AC, Bd, FCG, PiA)

Iwamoto, T. \& Sazonov, Y. I. (1988). A review of the southeastern Pacific Coryphaenoides (sensu lato) (Pisces, Gadiformes, Macrouridae). Proceedings of the California Academy of Sciences, 45, 35-82. (AC, Bd, FCB, FCG, PiA)

Jensen, M. P., Abreu-Grobois, F. A., Frydenberg, J., Loeschcke, V. 2006. Microsatellites provide insight into contrasting mating patterns in arribada vs. non-arribada olive ridley sea turtle rookeries. Molecular Ecology, 15, 2567-2575. (AC, Arb, Eg, Gn, Os, TM)

Jiménez-Centeno, C. E. (1998). Arrecifes y comunidades coralinas de Bahía Culebra, Pacifico Norte de Costa Rica. Tesis de Maestría, Universidad de Costa Rica. San Pedro, Costa Rica. 218 p. (Ar, BC, Eg, Te)

Jiménez, C. E. (1997). Corals and coral reefs of Culebra Bay, Pacific coast of Costa Rica: Anarchy in the reef. Proceedings of the 8th International Coral Reef Symposium, Panamá, 1, 329-334. (Ar, BC, Eg, Sm)

Jiménez, C. (2001a). Seawater temperature measured at the surface and at two depths (7 and $12 \mathrm{~m}$ ) in one coral reef at Culebra Bay, Gulf of Papagayo, Costa Rica. 
Revista de Biología Tropical, 49 (Suplemento 2), 153161. (AC, BC, OF)

Jiménez, C. (2001b). Arrecifes y ambientes coralinos de Bahía Culebra, Pacífico de Costa Rica: aspectos biológicos, económico-recreativos y de manejo. Revista de Biología Tropical, 49 (Suplemento 2), 215-231. (AC, Ar, BC, Eg, Ma, SE)

Jiménez, C. E. \& Cortés, J. (2003). Growth of seven species of scleractinian corals in an upwelling environment of the eastern Pacific (Golfo de Papagayo, Costa Rica). Bulletin of Marine Science, 72, 187-198. (AC, Af, Ar, BC, CnA, Eg)

Jiménez, C., Cortés, J., León, A. \& Ruiz, E. (2001). Coral bleaching and mortality associated with the1997-98 El Niño in an upwelling environment in the eastern Pacific (Gulf of Papagayo, Costa Rica). Bulletin of Marine Science, 69, 151-169. (AC, Af, Ar, BC, Eg, ENOS, IM)

Jiménez, C., Bassey, G., Segura, Á. \& Cortés, J. (2010). Characterization of the coral communities and reefs of two previously undescribed locations in the upwelling region of Gulf of Papagayo (Costa Rica). Revista de Ciencias Marinas y Costeras, 2, 95-108. (AC, $\mathrm{Ar}, \mathrm{BC}, \mathrm{BGu}, \mathrm{Eg})$

Jiménez J. A. (1981). The mangrove of Costa Rica: The physiognomic characterization. Tesis de Maestría, Universidad de Miami, Miami, Florda, E.U.A. 130 p. (Eg, Mg, PaN, Te)

Jiménez, J. \& Soto, R. (1985). Patrones regionales en la estructura y composición florística de los manglares de la costa Pacífica de Costa Rica. Revista de Biología Tropical, 33, 25-37. (AC, BS, Eg, Mg, Pt, Tr)

Jiménez-Hernández, F. M. (2013). Abundancia, diversidad taxonómica y distribución de los peces linternilla (Myctophidae) en el Pacífico de Costa Rica y Pana$m a ́$. Licenciatura en Biología con énfasis en Ecología y Gestión de Ambientes Acuáticos, Escuela de Biología, Universidad de Costa Rica. San Pedro, Costa Rica. 62 p. (Bd, CB, FCG, IT, PiA, Te, ZP)

Jörger, K., Meyer, R. \& Wehrtmann, I. S. (2008). Species composition and vertical distribution of chitons (Mollusca: Polyplacophora) in a rocky intertidal zone of the Pacific coast of Costa Rica. Journal of the Marine Biological Association of the United Kingdom, 88, 807-816 (AC, Bd, MoP, Sr)

Jung, P. (1989). Revision of the Strombina-Group (Gastropoda: Columbellidae), fossil and living: distribution, biostratigraphy and systematics. Schweizerische Paläontologische Abhandlungen, 111, 1-298. (BC, $\mathrm{Bd}, \mathrm{BEJ}, \mathrm{BU}, \mathrm{BJ}, \mathrm{Bl}, \mathrm{BP}, \mathrm{BS}, \mathrm{BSE}, \mathrm{Bt}, \mathrm{GP}, \mathrm{IM}, \mathrm{IT}$, IV, Mgr, MoG, PCy, PD, PdC, Po)

Karnauskas, K. B., Busalacchi, A. J. \& Murtugudde, R. (2008). Low-frequency variability and remote forcing of gap winds over the East Pacific Warm Pool. Journal of Climate, 21, 4901-4918. (AC, CA, GP)
Kawauchi, G. Y. \& Giribet, G. (2010). Are there true cosmopolitan sipunculan worms? A genetic variation study within Phascolosoma perlucens (Sipuncula, Phascolosomatidae). Marine Biology, 157, 14171431. (AC, Bd, BS, Gn, Si)

Kelmo, F. \& Vargas, R. (2002). Anthoathecatae and Leptothecatae hydroids from Costa Rica (Cnidaria: Hydrozoa). Revista de Biología Tropical, 50, 599-627. (AC, $\mathrm{Bd}, \mathrm{BU}, \mathrm{CnH}, \mathrm{Cy}, \mathrm{Oc}, \mathrm{PCh}, \mathrm{Pty})$

Kim, W. \& Abele, L. G. (1988). The snapping shrimp genus Alpheus from the eastern Pacific (Decapoda: Caridea: Alpheidae). Smithsonian Contributions to Zoology, 454, 1-119. (AC, BC, Bd, BS, BSE, CrD, PB, PdC)

Knight-Jones, P., Knight-Jones, E. W. \& Dales, R. P. (1979). Spirorbidae (Polychaeta Sedentaria) from Alaska to Panama. Journal of Zoology, London, 189, 419-458. (AC, Bd, PdC, Py)

Kong, L., Jing, H., Kataoka, T., Buchwald, C. \& Liu, H. (2013). Diversity and spatial distribution of Hydrazine Oxidoreductase ( $h z o$ ) gene in the Oxygen Minimum Zone off Costa Rica. PLoS ONE 8(10): e78275. doi:10.1371/journal.pone.0078275 (AC, DCR, FCG, OQ)

Lahmann, E. J. \& González, W. (1982). Observaciones sobre la distribución espacial y el comportamiento de Siphonaria gigas Sowerby, 1825 en la costa Pacífica de Costa Rica (Gastropoda: Siphonariidae). Anales del Instituto de Ciencias del Mar y Limnología, Universidad Nacional Autónoma de México, 9, 101-110. (AC, Eg, MoG, Mz)

Lalicker, C .G. \& McCulloch, I. (1940). Some Textulariidae of the Pacific Ocean. Allan Hancock Pacific Expeditions, 6(2), 115-143. (AC, BC, Bd, BS, BSE, Fo, PB)

Lanyon, A. (2011). Influencia de la temperatura y profundidad del mar en la distribución y abundancia del tiburón puntablanca Triaenodon obesus (Carcharhiniformes: Carcharhinidae) en el Golfo de Papagayo, Costa Rica. Licenciatura en Biología, Universidad Latina de Costa Rica, San José, Costa Rica. (Eg, ICa, PiE, Te)

Legeckis, R. (1988). Upwelling off the Gulfs of Panama and Papagayo in the tropical Pacific during March 1985. Journal of Geophysical Research, 93, 15 48515 489. (AC, Af, GP, OF)

Lindberg, D. R. \& McLean, J. H. (1981). Tropical Eastern Pacific limpets of the Family Acmaeidae (Mollusca, Archaeogastropoda): Generic criteria and descriptions of six new species from the mainland and the Galapagos Islands. Proceedings of the California Academy of Sciences, 42, 323-339. (AC, Bd, Bg, BS, $\mathrm{Gn}, \mathrm{MoG})$

Lillywhite, H. B., Brischoux, F., Sheehy III, C. M. \& Pfaller, J. B. (2012). Dehydration and drinking responses in a pelagic sea snake. Integrative and Comparative Biology, 52, 227-234. (AC, Eg, GP, Rp) 
Lizano, O. (2006). Algunas características de las mareas en la costa Pacífica y Caribe de Centroamérica. Ciencia y Tecnología, 24, 51-64. (AC, BC, OF)

Lizano, O. G. (2007). Climatología del viento y oleaje frente a las costas de Costa Rica. Ciencia y Tecnología, 25, 43-56. (AC, CA, OF)

Lizano R., O. G. (2013). Erosión en las playas de Costa Rica, incluyendo la Isla del Coco. Revista Intersedes, 24, 6-27. (AC, Cl, Er, Os, PGi, Tr)

Lizano, O. G. \& Alfaro, E. J. (2014). Características de la dinámica atmosférica y oceánica en algunas regiones del Área de Conservación Guanacaste (ACG), Costa Rica. Revista de Biología Tropical, 62 (Suplemento 4), 17-31. (AC, BC, B1, BSE, CA, OF, Tr)

Lizano, O. G., Alfaro, E. J. \& Salazar-Matarrita, A. (2012). Un método para evaluar el enriquecimiento de metales en sedimentos marinos en Costa Rica. Revista de Biología Tropical, 60 (Suplemento 2), 197-211. (AC, $\mathrm{BC}, \mathrm{CtM}, \mathrm{Sd})$

Lizano, O. G., Loría, L. G., Alfaro, E. J. \& Badilla, M. (2008). Distribución espacial de radionucleídos en sedimentos marinos de Bahía Culebra y el Golfo de Nicoya, Pacífico, Costa Rica. Revista de Biología Tropical, 56 (Suplemento 4), 83-90. (AC, BC, CtR, $\mathrm{Sd})$

López, M. I. \& Arias, C. (1987). Distribución temporal y espacial del ictioplancton en el estuario de Pochote, Bahía Ballena, Pacífico de Costa Rica. Revista de Biología Tropical, 35, 121-126. (AC, Bd, Bl, PiA, PII, Pt)

López, M. I. \& Bussing, W. A. (1998). Urotrygon cimar, a new eastern Pacific stingray (Pisces: Urolophidae). Revista de Biología Tropical, 46 (Suplemento 6), 271277. (AC, Bd, Mt, PiA, Tr)

Loría, M., L. G., Banichevich, A. \& Cortés, J. (1998). Radionucleidos en corales de Costa Rica. Revista de Biología Tropical, 46 (Suplemento 5), 81-90. (AC, CnA, CtR, IM)

Loría-Naranjo, M., Samper-Villarreal, J. \& Cortés, J. (2014). Potrero Grande and Santa Elena mangrove forest structure, Santa Rosa National Park, North Pacific, Costa Rica. Revista de Biología Tropical, 62 (Suplemento 4), 33-41. (AC, BSE, Eg, Mg, Po, PSR)

Lowe, H. N. (1932). Shell collecting in west Central America. The Nautilus, 45, 73-82. (AC, Bd, Ep, Hi, Mo)

Luke, S. R. (1977). Catalog of the benthic invertebrate collections. I. Decapod Crustacea and Stomatopoda. Scripps Institution of Oceanography Reference Series, No. 77-9, 72 p. (Bd, CB, Co, CrD, FCB, FPG, GP, ICB)

Luke, S.R. 1982. Catalog of the benthic invertebrate collections. Echinodermata. Scripps Institution of Oceanography Reference Series, No. 82-5, 66 p. (Bd, Co, Ec, FPG)
Luke, S.R. 1995. Catalog of the Benthic Invertebrate Collections of the Scripps Institution of Oceanography. Mollusca. Scripps Institution of Oceanography Reference Series, No. 95-24, 477 p. (Bd, BSE, Co, IM, GP, FCB, FPG, Mo)

Luke, S. R. 1998. Catalog of the Benthic Invertebrate Collections of the Scripps Institution of Oceanography. Coelenterata. Scripps Institution of Oceanography Reference Series, No. 98-02, 58 p. (Bd, Cn, Co, FPG, GP)

MacPherson, E. \& Wehrtmann, I. S. (2010). Occurrence of lithodid crabs (Decapoda, Lithodidae) on the Pacific coast of Costa Rica, Central America. Crustaceana, 83, 143-151. (AC, Bd, Bg, CrD, FPC)

Madrigal-Castro, E., Cabrera-Peña, J., Monge-Esquivel, J. \& Pérez-Acuña, F. (1984). Comparación entre dos poblaciones de Acanthina brevidentata (Gastropoda: Mollusca) en dos zonas rocosas de Playa Panamá, Guanacaste, Costa Rica. Revista de Biología Tropical, 32, 11-15. (AC, Eg, MoG, Pam, ZR)

Magaña, J., Espinosa, J. \& Ortea, J. (2003). Description of two new species Prunum Herrmannsen, 1852 (Mollusca: Gastropoda: Marginellidae) from the Caribbean and Pacific coast of Costa Rica. Avicennia, 16, 121-128. (AC, Bd, Ju, MoG)

Magaña, V. O., Amador, J. A. \& Medina, S. (1999). The midsummer drought over Mexico and Central America. Journal of Climate, 12, 1577-1588. (AC, CA, PaN)

Maldonado, T. \& Alfaro, E. J. (2010). Propuesta metodológica para la predicción climática estacional de eventos extremos y días con precipitación. Estudio de caso: Sur de América Central. Revista Intersedes, 11(21), 182214. (AC, CA, Gua)

Maldonado, T., Alfaro, E. J., Fallas, B. \& Alvarado, L. (2013). Seasonal prediction of extreme precipitation events and frequency of rainy days over Costa Rica, Central America, using Canonical Correlation Analysis. Advances in Geosciences, 33, 41-52. (AC, $\mathrm{CA}, \mathrm{PaN})$

Manning, R. B. (1961). A new Lysiosquilla (Crustacea: Stomatopoda) from the Gulf of California, with a rediscription of $L$. decemspinosa Rathbun. Proceedings of the Biological Society of Washington, 74, 29-35. (AC, Bd, CrS, PB)

Manning, R. B. (1971). Eastern Pacific Expeditions of the New York Zoological Society. Stomatopod Crustacea. Zoologica, 56, 95-113. (AC, BC, Bd, Bl, BSE, $\mathrm{CrS}, \mathrm{Sr})$

Manning, R. B. (1974). Stomatopods collected by Th. Mortensen in the eastern Pacific Region (Crustacea, Stomatopoda). Steenstrupia, 3(11), 101-109. (AC, $\mathrm{BC}, \mathrm{Bd}, \mathrm{BSE}, \mathrm{CrS}, \mathrm{Sr}$ )

Manning, R. B. \& Reaka, M. L. (1979). Three new stomatopod crustaceans from the Pacific coast of Costa 
Rica. Proceedings of the Biological Society of Washington, 92, 634-639. (AC, Bd, CrS, Sr)

Manter, H. W. (1940). Digenetic trematodes of fishes from the Galapagos Islands and the neighboring Pacific. Allan Hancock Pacific Expeditions, 2(14), 329-497. (AC, BC, Bd, PpP)

Marques, F., Brooks, D. R. \& Molina-Ureña, H. (1996). Two new species of Tetraphyllidean cestodes in Himantura pacifica (Chondrichthyes: Myliobatiformes: Dasyatididae) from the northwest coast of Costa Rica. Journal of Parasitology, 82, 302-306. (AC, Bd, Pam, PiE, PpP)

Marques, F., Centritto, R. \& Stewart, S. A., (1997). Two new species of Acanthobothrium in Narcine entemedor (Rajiformes: Narcinidae) from the northwest coast of Guanacaste Peninsula, Costa Rica. Journal of Parasitology, 83, 927-931. (AC, Bd, Cu, PiE, PpA)

Martínez-Fernández, D. (2007). Ocurrencia y comportamiento de cetáceos en el Pacifico norte y sur de Costa Rica, determinación poblacional de Pseudorca crassidens y medidas de conservación para la comunidad de Bahía Drake. Tesis de Maestría en Manejo y Conservación de Vida Silvestre. ICOMVIS, Universidad Nacional, Heredia, Costa Rica. 95 p. (Bd, Eg, FCG, MM, Te)

Martínez-Fernández, D., Montero-Cordero, A. \& MayCollado, L. (2011). Cetáceos de las aguas costeras del Pacífico norte y sur de Costa Rica. Revista de Biología Tropical, 59, 283-290. (AC, Bd, FCG, MM)

Martínez-Fernández, D., Montero-Cordero, A. \& PalaciosAlfaro, D. (2014). Áreas de congregación de cetáceos en el Pacífico norte de Costa Rica: propuestas para su manejo. Revista de Biología Tropical, 62 (Suplemento 4), 99-108. (AC, BSE, CB, Cu, Eg, FCG, GP, IM, MM, PR, Tr)

May-Collado, L. J. (2001). Ecología y comportamiento del delfin manchado costero, Stenella attenuata graffmani (CETACEA: DELPHINIDAE) del Pacifico norte de Costa Rica. Tesis de Maestría, Universidad de Costa Rica. San Pedro, Costa Rica. 78 p. (Cm, Eg, GP, MM, Te)

May-Collado, L. (2009). Marine mammals. In I. S. Wehrtmann \& J. Cortés (Eds.), Marine Biodiversity of Costa Rica, Central America (Texto: pp. 479-495, Lista de especies: Disco Compacto pp. 485-490). Berlin: Springer. (BC, Bd, Cp, GP, IC, IM, MM)

May-Collado, L. J. \& Forcada, J. (2012). Small-scale estimation of relative abundance for the coastal spotted dolphins (Stenella attenuata) in Costa Rica: the effect of habitat and seasonality. Revista de Biología Tropical, 60 (Suplemento 2), 133-142. (AC, Eg, GP, MM)

May-Collado, L. \& Morales-Ramírez, A. (2005). Presencia y patrones de comportamiento del delfín manchado costero, Stenella attenuata (Cetacea: Delphinidae) en el Golfo de Papagayo, Costa Rica. Revista de
Biología Tropical, 53, 265-276. (AC, Cm, Eg, GP, $\mathrm{MM})$

May-Collado, L., Gerrodette, T., Calambokidis, J., Rasmussen, K \& Sereg, I. (2005). Patterns of cetacean sighting distribution in the Pacific Exclusive Economic Zone of Costa Rica based on data collected from 1979-2001. Revista de Biología Tropical, 53, 249-263. (AC, Bg, GP, MM)

McCauley, D. J., Joyce, F. J. \& Lowenstein, J. H. (2008). Effects of the aquarium fish industry in Costa Rica on populations of the Cortez rainbow wrasse Thalassoma lucasanum. Ciencias Marinas, 34, 445-451. (AC, $\mathrm{Cu}, \mathrm{IM}, \mathrm{Eg}, \mathrm{Pe}, \mathrm{PiA})$

McCosker, J. E. \& Rosenblatt, R. H. (1998). A revision of the eastern Pacific snake-eel genus Ophichthus (Anguilliformes: Ophichthidae) with the description of six new species. Proceedings of the California Academy of Sciences, 50: 397-432. (AC, Bd, FCB, FCG)

McCoy, C. J., Vogt, R. C. \& Censky, E. J. (1983). Temperature-controlled sex determination in the sea turtle Lepidochelys olivacea. Journal of Herpetology, 7, 406. (AC, Eg, Na, TM)

McCreary, J. P., Lee, H. S. \& Enfield, D. B. (1989). The response of the coastal ocean to strong offshore winds: with application to circulations in the Gulfs of Tehuantepec and Papagayo. Journal of Marine Research, 47, 81-109. (AC, Af, GP, OF)

McLaughlin, P. A. (1981). Revision of Pylopagurus and Tomopagurus (Crustacea: Decapoda: Paguridae), with the descriptions of new genera and species: Part II. Rhodochirus McLaughlin and Phimochirus McLaughlin. Bulletin of Marine Science, 31, 329365. (AC, BC, Bd, BEJ, BU, CrD)

McLean, J. H. \& Poorman, R. (1971). New species of Tropical Eastern Pacific Turridae. The Veliger, 14, 89-113. (AC, BC, Bd, MoG)

Méndez-Venegas, M. (2014). Estado de conservación del arrecife coralino de Playa Blanca (Matapalo), uno de los arrecifes más extensos de la costa Pacífica de Costa Rica. Tesis de Maestría, Universidad Nacional, Heredia, Costa Rica. 77 p. (Ar, Cv, Eg, Mt, Te)

Menzies, R. J. (1953). The apseudid Chelifera of the eastern tropical and north temperate Pacific Ocean. Bulletin of the Museum of Comparative Zoology, 107, 441-496. (AC, Bd, BSE, CrT, PB)

Meserve, F. G. (1938). Some monogenetic trematodes from the Galapagos Islands and the neighboring Pacific. Allan Hancock Pacific Expeditions, 2(5), 31-89. (AC, $\mathrm{BC}, \mathrm{Bd}, \mathrm{PiA}, \mathrm{PpP})$

Miller, A. C. (1974). A Comparison of Gastropod Diversity and Trophic Structure in the Rocky Intetidal Zone of the Temperate and Tropical West America. Disertación doctoral, Universidad de Oregon, Eugene, 
Oregon, E.U.A. 144 p. (BC, Bd, Bg, Eg, MoG, Sr, Te, ZR)

Miller, A. C. (1983). A comparison of the species richness and roles of gastropods and chitons on rocky shores of temperate and tropical West America. The Veliger, 26, 62-68. (AC, BC, Bd, Bg, Eg, MoG, Sr, ZR)

Miranda, F. (1997). El turismo y la convivencia communal en un área rural-costera. Revista Geográfica de América Central, 35, 107-138. (AC, Tu, Mz)

Monks, S., Marques, F., León-Régagnon, V. \& PérezPonce de León, G. (1997). Koronacantha pectinaria n. comb. (Acanthocephala: Illiosentidae) from Microlepidotus brevipinnis (Haemulidae) and redescription of Tegorhynchus brevis. Journal of Parasitology, 83, 485-494. (AC, BC, Bd, PiA, PpA)

Mora, J. M. \& Robinson, D. C. (1984). Predation of sea turtle eggs (Lepidochelys) by the snake Loxocemus bicolor. Revista de Biología Tropical, 32, 161-162. (AC, Eg, Na, Os, Rp, TM)

Morales-Ramírez, A. \& Suárez-Morales, E. (2009). Copepods. In I. S. Wehrtmann \& J. Cortés (Eds.), Marine Biodiversity of Costa Rica, Central America (Texto: pp. 291-305, Lista de especies: Disco Compacto pp. 224-236). Berlin: Springer. (BC, Bd, Cp, CrC)

Morales-Ramírez, A., Víquez, R., Rodríguez, K. \& Vargas, M. (2001). Marea roja producida por Lingulodinium polyedrum (Peridiniales, Dinophyceae) en Bahía Culebra, Golfo de Papagayo, Costa Rica. Revista de Biología Tropical, 49 (Suplemento 2), 19-23. (AC, BC, Di, FAN)

Morales-Zuñiga, L. C. (2011). Desarrollo humano y desarrollo turístico: el caso del cantón de Santa Cruz de Guanacaste. Revista de Población y Salud en Mesoamérica, 8(2), 1-20. (AC, Gua, Tu)

Moran, D. A. \& Dittel, A. I. (1993). Anomura and Brachyuran crabs of Costa Rica: annotated list of species. Revista de Biología Tropical, 41, 599-617. (AC, Bd, $\mathrm{CB}, \mathrm{CrD}, \mathrm{BP}, \mathrm{FCB}$; IM, PCh

Morreale, S. J., Standora, E. A., Spotila, J. R. \& Paladino, F. V. (1996). Migration corridor for sea turtles. Nature, 384, 319-320. (AC, Eg, PG, TM)

Muller-Parker, G. \& Cortés, J. (2001). Spatial distribution of light and nutrients in some coral reefs of Costa Rica during January 1997. Revista de Biología Tropical, 49 (Suplemento 2), 251-263. (AC, Ar, BC, Eg, $\mathrm{OF}, \mathrm{OQ})$

Myers, A. A. (1968). Some Aoridae (Amphipoda: Gammaridae) collected by the Hancock Expeditions to the eastern Pacific, 1931-1941. Pacific Science, 22, 497-506. (AC, Bd, BS, CrA)

Naranjo, H. (2010). Caracterización de los sistemas operacionales, modalidades y artes de pesca utilizados para la captura de la langosta Panulirus gracilis (Streets, 1871) en Guanacaste, Costa Rica. Revista de Ciencias
Marinas y Costeras, 2, 73-82. (AC, BSJ, CrD, Ma, PLg, PR)

Nordmoe, E. D., Sieg, A. E., Sotherland, P. R., Spotila, J. R., Paladinos, F. V. \& Reina, R. D. (2004). Nest site fidelity of leatherback turtles at Playa Grande, Costa Rica. Animal Behavour, 68, 387-394. (AC, Cm, Eg, PG, TM)

Nova-Bustos, N. C. (2008). Ascideas asociadas a sustrato duro en Bahía Cuajiniquil, Pacífico de Costa Rica. Tesis de Licenciatura, Universidad Nacional, Heredia, Costa Rica. 53 p. (Bd, Cu, Te, Tn)

Nova-Bustos, N., Hernández-Zanuy, A. C. \& ViquezPortuguez, R. (2010). Distribución y abundancia de las ascidias de los fondos rocosos de la Bahía de Cuajiniquil, Costa Rica. Boletín de Investigaciones Marinas y Costeras, 39, 57-66. (AC, Bd, Cu, Tn)

Oliveira, J. B., Morales, J. A., González-Barrientos, R. C., Hernández-Gamboa, J., Hernández-Mora, G. (2011). Parasites of cetaceans stranded on the Pacific coast of Costa Rica. Veterinary Parasitology, 182, 319-328. (AC, B1, BS, MM, PG, PH, PMM, Ta, Tr)

Osburn, R. C. (1950). Bryozoa of the Pacific Coast of America. Part I, Cheilostomata-Anasca. Allan Hancock Pacific Expeditions, 14, 1-269. (AC, BC, Bd, $\mathrm{Br}, \mathrm{BSE}, \mathrm{PdC})$

Osburn, R. C. (1952). Bryozoa of the Pacific Coast of America. Part 2, Cheilostomata-Ascophora. Allan Hancock Pacific Expeditions, 14, 271-611. (AC, BC, $\mathrm{Bd}, \mathrm{Br}, \mathrm{BS}, \mathrm{BSE}, \mathrm{PB}, \mathrm{PdC})$

Osburn, R. C. (1953). Bryozoa of the Pacific Coast of America. Part 3, Cyclostomata, Ctenostomata, Entoprocta, and Addenda. Allan Hancock Pacific Expeditions, 14, 613-725. (AC, Bd, Br, BSE, PB)

Osburn, R. C. \& Soule, J. D. (1953). Bryozoa of the Pacific Coast of America. Part 3, Order Ectoprocta. Allan Hancock Pacific Expeditions, 14, 726-758. (AC, BC, $\mathrm{Bd}, \mathrm{Br}$ )

Pacheco-Solano, C. 2012. Estudio taxonómico de las esponjas perforadoras (Porifera, Demospongiae) de arrecifes de coral del Pacifico de Costa Rica. Tesis de Licenciatura en Biología, Universidad de Costa Rica. San Pedro, Costa Rica. 69 p. (BC, Bd, Bi, BS, Te)

Pepe, P. J. (1985). Littoral endolithic fauna of the Central American Isthmus. Revista de Biología Tropical, 33, 191-194. (AC, Bi, Eg, MoB, PdC, Py, Si)

Pérez-Ponce de León, G., León-Règagnon, V. \& Monks, S. (1998). Theletrum lamothei sp. nov. (Digenea), parasite of Echidna nocturna from Cuajiniquil, Guanacaste, and other digenes of marine fishes from Costa Rica. Revista de Biología Tropical, 46, 345-354. (AC, $\mathrm{BC}, \mathrm{Bd}, \mathrm{Cu}, \mathrm{Oc}, \mathrm{PiA}, \mathrm{PpP})$

Perger, R., Cortés, J. \& Pacheco, C. (2013). Closing a distributional gap of over $3000 \mathrm{~km}$ and encountering an invisible barrier: new presence/absence data for 
Johngarthia planata Stimpson, 1860 (Decapoda, Brachyura, Gecarcinidae) for Central America and biogeographic notes on East Pacific Gecarcinidae. Crustaceana, 86, 268-277. (AC, Bg, CrD, IM)

Petrescu, I. \& Heard, R. W. (2004). Three new Cumacea (Crustacea: Peracarida) from Costa Rica. Zootaxa, 721, 1-12. (AC, Bd, CrQ, IM)

Petrescu, I., Heard, R. W., Vargas, R. \& Breedy, O. (2009). Cumaceans. In I. S. Wehrtmann \& J. Cortés (Eds.), Marine Biodiversity of Costa Rica, Central America (Texto: pp. 237-244, Lista de especies: Disco Compacto pp. 201-203). Berlin: Springer. (Bd, Cp, CrQ, IM)

Pfaller, J. B., Frick, M. G., Brischoux, F., Sheehy III, C.M. \& Lillywhite, H. B. (2012). Marine snake epibiosis: A review and first report of Decapods associated with Pelamis platurus. Integrative and Comparative Biology, 52, 296-310. (AC, CrD, Eg, FCG, GP, Rp)

Pfeiler, E. (2008). Resurrection of the name Albula pacifica (Beebe, 1942) for the shafted bonefish (Albuniformes: Albulidae) from the eastern Pacific. Revista de Biología Tropical, 56, 839-844. (AC, BC, Bd, PiA)

Piedra, R., Vélez, E., Dutton, P., Possardt, E. \& Padilla, C. (2007). Nesting of the Leatherback Turtle (Dermochelys coriacea) from 1999-2000 through 2003-2004 at Playa Langosta, Parque Nacional Marino Las Baulas de Guanacaste, Costa Rica. Chelonian Conservation and Biology, 6, 111-116. (AC, Eg, PNB, TM)

Pilsbry, H. A. \& Lowe, H. N. (1932). West Mexican and Central American Mollusks collected by H.N. Lowe, 1929-31. Proceedings of the Academy of Natural Sciences of Philadelphia, 84, 33-144. (AC, Bd, BSE, $\mathrm{MoB}, \mathrm{MoG})$

Pizarro, F. \& Angulo, H. (1994). Diagnóstico de los manglares de la costa Pacífica de Costa Rica. In J. F. Angulo \& H. Suman (Eds.), El ecosistema de manglar en América Latina y la Cuenca del Caribe: su manejo y conservación (pp. 34-63). Miami, Florida: Universidad de Miami. (Cp, Mg, Pt, Tr)

Plotkin, P., Polar, M. \& Owens, D. W. (1991). Observations on olive ridley sea turtle behavior prior to an arribada at Playa Nancite, Costa Rica. Marine Turtle Newsletter, 53, 9. (AC, Arb, Cm, Na)

Plotkin, P. T., Byles, R. A., Rostal, D. C. \& Owens, D. W. (1995). Independent versus socially facilitated oceanic migrations of the olive ridley, Lepidochelys olivacea. Marine Biology, 122, 137-143. (AC, Eg, Na, TM)

Plotkin, P. T., Briceño-Dueñas, R. \& Abreu-Grobois, F. A. (2012). Interpreting signs of olive ridley recovery in the Eastern Pacific. In J. A. Seminoff \& B. P. Wallace (Eds.), Sea Turtles of the Eastern Pacific: Advances in Research and Conservation. (pp. 302-335). Tucson: The University of Arizona Press. (Cp, Cv, Na, Os, TM)
Pola, M., Camacho-García, Y. \& Gosliner, T. (2012). Molecular data illuminate cryptic nudibranch species: The evolution of the Scyllaeidae (Nudibranchia: Dendronotina) with a revision of Notobryon. Zoological Journal of the Linnean Society, 165, 311-336. (AC, $\mathrm{Bd}, \mathrm{Gn}, \mathrm{ICa}, \mathrm{MoG})$

Pool, D. J., Snedaker, S. C. \& Lugo, A. E. (1977). Structure of mangrove forests in Florida, Puerto Rico, Mexico, and Costa Rica. Biotropica, 9, 195-212. (AC, Eg, $\mathrm{Mg}, \mathrm{PSR})$

Price, W. W., Heard, R. W. \& Vargas, R. (2009). Shallow water mysids. In I. S. Wehrtmann \& J. Cortés (Eds.), Marine Biodiversity of Costa Rica, Central America (Texto: pp. 229-236, Lista de especies: Disco Compacto pp. 199-200). Berlin: Springer. (Bd, Cp, CrMi, IM)

Putz, F. E., Parker, G. G. \& Archibald, R. M. (1984). Mechanical abrasion and intercrown spacing. American Midland Naturalist, 112, 24-28 (AC, Eg, Mg, PSR)

Quackenbush, S. L., Casey, R. N., Murcek, R. J., Paul, T. A., Work, T. M., Limpus, C. J., Chaves, A., duToit, L., Vasconcelos-Perez, J., Aguirre, A. A., Spraker, T. R., Horrocks, J. A., Vermeer, L. A., Balazs, G. H. \& Casey, J. W. (2001). Quantitative analysis of Herpesvirus sequences from normal tissue and fibropapillomas of marine turtles with Real-Time PCR. Virology, 287. 105-111. (AC, En, Ge, Mi, TM)

Rafferty, A. R., Santidrián-Tomillo, P., Spotila, J. R., Paladino, F. V., Reina, R. D. (2011) Embryonic death is linked to maternal identity in the Leatherback Turtle (Dermochelys coriacea). PLoS ONE 6(6), e21038. doi:10.1371/journal.pone.0021038 (AC, Eg, PG, TM)

Rasmussen, K., Palacios, D. M., Calambokidis, J., Saborío, M. T., Dalla-Rosa, L., Secchi, E. R. \& Stone, G. S. (2007). Southern Hemisphere humpback whales wintering off Central America: insights from water temperature into the longest mammalian migration. Biology Letters, 3, 302-305. (AC, Bg, GP, MM)

Rasmussen, K., Calambokidis, J. \& Steiger, G. H. (2012). Distribution and migratory destinations of humpback whales off the Pacific coast of Central America during the boreal winters of 1996-2003. Marine Mammal Science, 28(3), 267-279. (AC, Bg, FCG, MM)

Rathbun, M. J. (1937). The Oxystomatous and allied crabs of America. United States National Museum, Bulletin, 166, 1-272. (AC, BC, Bd, CrD)

Reid, D. G. (1999). The genus Littoraria Griffith \& Pidgeon, 1834 (Gastropoda: Littorinidae) in the tropical eastern Pacific. The Veliger, 42, 21-53. (AC, BSE, MoG, Tr)

Reid, D. G. (2002). The genus Nodilittorina von Martens, 1897 (Gastropoda: Littorinidae) in the eastern Pacific Ocean, with a discussion of Biogeographic Provinces 
of the rocky-shore fauna. The Veliger, 45, 85-170. (AC, BC, Bd, BEJ, BSE, IM, MoG, PdC, Pen, Tr, ZR)

Reina, R. D., Mayor, P. A., Spotila, J. R., Piedra, R. \& Paladino, F. V. (2002). Nesting ecology of the leatherback turtle, Dermochelys coriacea, at Parque Nacional Marino Las Baulas, Costa Rica: 1988-1989 to 19992000. Copeia, 2002, 653-664. (AC, Eg, PNB, TM)

Richard, J. D. \& Hughes, D. A. (1972). Some observations of sea turtle nesting activity in Costa Rica. Marine Biology, 16, 297-309. (AC, Arb, Eg, Na, No, Os, PG, PL, TM, Tr)

Ríos, R. (1986). Caridean shrimps of the Gulf of California. V. New records of species belonging to the subfamily Pontoniinae (Crustacea: Decapoda: Palaemonidae). Proceedings of the Biological Society of Washington, 99, 429-434. (AC, Bd, CrD, IV)

Rivera-Chavarría, M. (2012). Odontoscion xanthops Gilbert, 1898 (Pisces: Sciaenidae) sounds as reef disturbance indicators. Brenesia, 78, 74-77. (AC, Cu, Eg, IT, PiA)

Rixen, T., Jiménez, C. \& Cortés, J. (2012). Impact of upwelling events on the sea water chemistry in the Gulf of Papagayo (Culebra Bay), Costa Rica. Revista de Biología Tropical, 60 (Suplemento 2), 187-195. (AC, Af, BC, OF, OQ)

Robinson, N. M., Hansen, G. I., Fernández-García, C. \& Riosmena-Rodríguez, R. (2013). A taxonomic and distributional study of the rhodolith-forming species Lithothamnion muelleri (Corallinales, Rhodophyta) in the Eastern Pacific Ocean. Algae, 28, 63-71. (AC, $\mathrm{Al}, \mathrm{BC}, \mathrm{Bd}, \mathrm{Bg})$

Rodgers III, J. C. \& Horn, S. P. (1996). Modern pollen spectra form Costa Rica. Palaeogreography Palaeoclimatology, Palaeoecology, 124, 53-71. (AC, Eg, $\mathrm{Mg}, \mathrm{Pol}, \mathrm{PSR})$

Rodríguez-Ortíz, B., García-Prieto. L. \& Pérez-Ponce de León, G. (2004). Checklist of the helminth parasites of vertebrates in Costa Rica. Revista de Biología Tropical, 52, 313-354. (AC, BC, Bd, Cu, Ju, Oc, Pam, $\mathrm{PH}, \mathrm{PpA}, \mathrm{PpN}, \mathrm{PpP})$

Rodríguez-Sáenz, K. (2005). Distribución espacial y temporal de la biomasa, composición y abundancia del zooplancton, con énfasis en hidromedusas de Bahía Culebra durante La Niña 1999 y el 2000. Tesis de Maestría, Universidad de Costa Rica. San José, Costa Rica. 156 p. (BC, Bd, CnH, CnM, Eg, LN, P1Z, Te)

Rodríguez-Sáenz, K. \& Gasca, R. (2009). Siphonophores. In I. S. Wehrtmann \& J. Cortés (Eds.), Marine Biodiversity of Costa Rica, Central America (Texto: pp. 151-156, Lista de especies, DISCO COMPACTO: pp. 101-104). Berlin: Springer. (BC, Bd, CnH, Cp, PlZ)

Rodríguez-Sáenz, K. \& Morales-Ramírez, A. (2012). Composición, distribución espacial y temporal de la abundancia del mesozooplancton en una zona de afloramiento costero (Bahía Culebra, Pacífico Norte de Costa Rica) durante La Niña 1999 y el 2000. Revista de Biología Tropical, 60 (Suplemento 2), 143157. (AC, BC, Bd, CnM, Eg, PlZ)

Rodríguez-Sáenz, K. \& Rodríguez-Fonseca, J. (2004). Avistamientos del delfín manchado, Stenella attenuata (Cetacea: Delphinidae) en Bahía Culebra, Costa Rica, 1999-2000. Revista de Biología Tropical, 52 (Suplemento 2), 189-193. (AC, BC, Eg, MM)

Rodríguez-Sáenz, K. \& Segura-Puertas, L. (2009). Hydrozoa, Scyphozoa, and Cubozoa (Medusozoa). In I. S. Wehrtmann \& J. Cortés (Eds.), Marine Biodiversity of Costa Rica, Central America (Texto: pp. 143-149, Lista de especies, DISCO COMPACTO: pp. 94-100). Berlin: Springer. (BC, Bd, CnH, CnM, Cp, PlZ)

Rodríguez-Sáenz, K., Vargas-Zamora, J. A. \& SeguraPuertas, L. (2012). Medusas (Cnidaria: Hydrozoa) de una zona de afloramiento costero, Bahía Culebra, Pacífico, Costa Rica. Revista de Biología Tropical, 60, 1731-1748. (AC, BC, Bd, CnH, Eg, PlZ)

Roe, J. H., Sill, N. S., Columbia, M. R., Paladino, F. V. (2011) Trace metals in eggs and hatchlings of Pacific Leatherback Turtles (Dermochelys coriacea) nesting at Playa Grande, Costa Rica. Chelonian Conservation and Biology, 10, 3-9. (AC, CtM, PG, TM)

Roe, J. H., Clune, P. R., Paladino, F. V. (2013) Characteristics of a Leatherback nesting beach and implications for coastal development. Chelonian Conservation and Biology, 12, 34-43. (AC, Cv, Ma, PG, TM, Tu)

Rosenblatt, R. H. \& McCosker, J. E. (1988). A new species of Acanthemblemaria from Malpelo Island, with a key to the Pacific members of the genus (Pisces: Chaenopsidae). Proceedings of the California Academy of Sciences, 45, 103-110. (AC, Bd, BSE, PiA)

Rost, H. (1955). A report on the Family Arcidae (Pelecypoda). Allan Hancock Pacific Expeditions, 20, 177-249. (AC, BC, Bd, BS, BSE, MoB, PB, PdC)

Rostal, D. C., Paladino, F. V., Patterson, R. M. \& Spotilla, J. R. (1996). Reproductive physiology of nesting leatherback turtles (Dermochelys coriacea) at Las Baulas National Park, Costa Rica. Chelonian Conservation and Biology, 2, 230-236. (AC, Eg, PNB, TM)

Roth, F. (2014). Effects of simulated overfishing on the succession of benthic algae and invertebrates in upwelling-influenced coral reefs of Pacific Costa Rica. Tesis de Maestría, ISATEC, University of Bremen. Bremen, Alemania. 44 p. (Af, Al, Ar, Eg, Mt, Pe, Te)

Rowe, C. (2011). Fishing Away Marine Conservation: Poverty, Resource Dependence, and Poor Management in Cuajiniquil, Costa Rica. Tesis de Bachillerato, Amherst College, Amherst, Massachusetts. 97 p. (AMP, Cv, Cj, Ma, PSR, Te)

Saba, V. S. (2012). Sea turtles in the tropical high seas. In J. A. Seminoff \& B. P. Wallace (Eds.), Sea Turtles 
of the Eastern Pacific: Advances in Research and Conservation. (pp. 39-62). Tucson: The University of Arizona Press. (Cp, ENOS, OF, PNB, TM)

Saba, V. S., Shillinger, G. L., Swithenbank, A. M., Block, B. A., Spotila, J. R., Musick, J. A. \& Paladino, F. V. (2008). An oceanographic context for the foraging ecology of eastern Pacific leatherback turtles: Consequences of ENSO. Deep-Sea Research I, 55, 646660. (AC, Eg, ENOS, OF, PNB, TM)

Sáenz, J. C. \& Espach, H. E. (2011). Predation of Olive Ridley sea turtle neonates by Collared Peccaries, Pecari tajacu (Artiodactyla: Tayassuidae). Brenesia, 75-76, 118-120. (AC, Eg, Na, TM)

Salas-Campos, I. (1988). Análisis de la flora bacteriana de los nidos de tortuga marina Lepidochelys olivacea en Playa Nancite, 1987. Licenciatura en Microbiólogía Química Clínicoa, Facultad de Microbiología, Universidad de Costa Rica, San Pedro, San José, Costa Rica. (Mi, Na, Te, TM)

Salazar, A., Lizano, O. G. \& Alfaro, E. J. (2004). Composición de sedimentos en las zonas costeras de Costa Rica utilizando Fluorescencia de Rayos-X (FRX). Revista de Biología Tropical, 52 (Suplemento 2), 61-75. (AC, BC, BS, Cr, Ju, Ml, Mz, PCy, PdC, PGa, PGi, Pis, PlA, PSM, PSR, Sd, Sr, Ta)

Samper-Villareal, J., Cortés, J. \& Benavides, C. (2012). Forest structure and area of mangrove stands at Bahía Culebra, northern Pacific coast of Costa Rica. Revista de Biología Tropical, 60 (Suplemento 2), 109-120. (AC, BC, Eg, Mg, PI, Pam)

Sánchez-Jiménez, A., Morales-Ramírez, Á., Samper-Villarreal, J. \& Sánchez-Noguera, C. (2014). Percepción comunitaria sobre el uso y manejo de los recursos marino costeros en el Pacífico Norte de Costa Rica: Recomendaciones para una gestión integral de las zonas costeras. Revista de Biología Tropical, 62 (Suplemento 4), 139-149. (AC, Cj, Ma, Mz, SE)

Sánchez-Noguera, C. (2012a). Cambios socioeconómicos y ambientales en Bahía Culebra, Guanacaste, Costa Rica: implicaciones para su gestión. Tesis de Maestría, GIACT, Universidad de Costa Rica, San Pedro, San José, Costa Rica. 142 p. (BC, Hi, Te)

Sánchez-Noguera, C. (2012b). Entre historias y culebras: más que una bahía (Bahía Culebra, Guanacaste, Costa Rica). Revista de Biología Tropical, 59 (Suplemento 2), 1-17. (AC, BC, Hi, SE)

Santidrián-Tomillo, P., Vélez, E., Reina, R. D., Piedra, R., Paladino, F. V. \& Spotila, J. R. (2007). Reassessment of the Leatherback Turtle (Dermochelys coriacea) nesting population at Parque Nacional Marino Las Baulas, Costa Rica: Effects of conservation efforts. Chelonian Conservation and Biology, 6, 54-62. (AC, Eg, PNB, TM)

Santidrián-Tomillo, P., Saba, V. S., Piedra, R., Paladino, F. V. \& Spotila, J. R. (2007).Effects of illegal harvest of eggs on the population decline of leatherback turtles in Las Baulas Marine National Park, Costa Rica. Conservation Biology, 22(5), 1216-1224. (AC, Cv, Eg, PNB, TM)

Santidrián-Tomillo, P., Suss, J. S., Wallace, B. P., Magrini, K. D., Blanco, G., Paladino, F. V. \& Spotila, J. R. (2009). Influence of emergence success on the annual reproductive output of leatherback turtles. Marine Biology, 156, 2021-2031. (AC, Eg, PG, TM)

Santidrián-Tomillo P., Saba V. S., Blanco, G. S., Stock, C. A., Paladino, F. V. \& \& Spotila, J. R. (2012). Climate driven egg and hatchling mortality threatens survival of Eastern Pacific leatherback turtles. PLoS ONE 7(5): e37602. doi:10.1371/journal.pone.0037602. (AC, CC, Eg, ENOS, PG, TM)

Santidrián-Tomillo, P., Oro, D., Paladino, F. V., Piedra, R., Sieg, A. E., Spotila, J. R. (2014). High beach temperatures increased female-biased primary sex ratios but reduced output of female hatchlings in the leatherback turtle. Biological Conservation, 176, 71-79. (AC, Eg, ENOS, PG, TM)

Santoro, M. \& Morales, J. A. (2007). Some digenetic trematodes of the olive ridley sea turtle, Lepidochelys olivacea (Testudines, Cheloniidae) in Costa Rica. Helminthologia, 44, 25-28. (AC, Bd, Os, PTP, TM)

Santoro, M., Orrego, C. M. \& Hernández-Gómez, G. (2006). Flora bacteriana clocal y nasal de Lepidochelys olivacea (Testudines, Cheloniidae) en el Pacífico norte de Costa Rica. Revista de Biología Tropical, 54, 43-48. (AC, Bd, Na, PTB, TM)

Sasai, Y., Richards, K. J., Ishida, A., Sasaki, H. (2012). Spatial and temporal variabilities of the chlorophyll distribution in the northeastern tropical Pacific: The impact of physical processes on seasonal and interannual time scales. Journal of Marine Systems, 96-97, 24-31. (AC, DCR, OF)

Sauer, J. D. (1975). Remnant seashore vegetation of northwest Costa Rica. Madroño, 23, 174-181. (AC, BC, PG, Tr, VG)

Savage, J. M. (2002). The Amphibians and Reptiles of Costa Rica: A Herpetofauna Between Two Continents, Between Two Seas. Chicago y Londres: University of Chicago Press. 934 p. (BC, Bd, Li, Rp, TM)

Schmitt, W. L. (1940). The Stomatopods of the West Coast of America, based on collections made by the Allan Hancock Expeditions, 1933-38. Allan Hancock Pacific Expeditions, 5(4), 129-225. (AC, BC, Bd, BS, BSE, CrS)

Schulze, A., Cutler, E. B. \& Giribet, G. (2007). Phylogeny of sipunculan worms: A combined analysis of four gene regions and morphology. Molecular Phylogenetics and Evolution, 42, 171-192. (AC, Bd, Fi, Si, Tr)

Schwengel, J. S. (1955). New Conus from Costa Rica. The Nautilus, 69: 13-15. (AC, Bd, BS, MoG, PdC) 
Setchell, W. A. (1937). The Templeton Crocker Expedition of the California Academy of Sciences, 1932. Number 34. Reports on the Sargassum. Proceedings of the California Academy of Sciences, Series 4, 22, 127-158. (AC, Al, Bd, BSE, IM)

Sheehy, C. M. III, Solórzano, A., Pfaller, J. B. \& Lillywhite, H. B. (2012). Preliminary insights into the phylogeography of the yellow-bellied sea snake, Pelamis platurus. Integrative and Comparative Biology, 52, 321-330. (AC, BC, Fg, Rp)

Shillinger, G. L., Palacios, D. M., Bailey, H., Bograd, S. J., Swithenbank, A. M., Gaspar, P., Wallace, B. P., Spotila, J. R., Paladino, F. V., Piedra, R., Eckert, S. A. \& Block, B. A. (2008). Persistent Leatherback Turtle migrations present opportunities for conservation. PLoS Biology, 6(7), e171. doi:10.1371/journal. pbio.0060171. (AC, Cv, Eg, PG, TM)

Shillinger, G. L., Swithenbank, A. M., Bograd, S. J., Bailey, H., Castelton, M. R., Wallace, B. P., Spotila, J. R., Paladino, F. V., Piedra, R. \& Block, B. A. (2010). Identification of high-use internesting habitats for eastern Pacific leatherback turtles: role of the environment and implications for conservation. Endangered Species Research, 10, 215-232. (AC, Cv, Eg, PNB, TM)

Shillinger, G. L., Di Lorenzo, E., Luo, H., Bograd, S. J., Hazen, E. L., Bailey, H. \& Spotila, J. R. (2012). On the dispersal of leatherback turtle hatchlings from Mesoamerican nesting beaches. Proceedings of the Royal Society, Biology, 279, 2391-2395. (AC, Eg, PG, PNB, TM)

Sibaja-Cordero, J. A. \& Cortés, J. (2008). Vertical zonation of rocky intertidal organisms in a seasonal upwelling area (Eastern Tropical Pacific). Revista de Biología Tropical, 56 (Suplemento 4), 91-104. (AC, BS, Eg, ZR)

Sibaja-Cordero, J. A. \& García-Méndez, K. (2014). Variación espacial y temporal de los organismos de un intermareal rocoso, Bahía Panamá, Pacífico Norte, Costa Rica. Revista de Biología Tropical, 62 (Suplemento 4), 85-97. (AC, BC, Eg, ZR)

Sibaja-Cordero, J. A., Camacho-García, Y. E. \& VargasCastillo, R. (2014). Riqueza de especies de invertebrados en playas de arena y costas rocosas del Pacífico Norte de Costa Rica. Revista de Biología Tropical, 62 (Suplemento 4), 63-84. (AC, Bd, BSE, CB, Cby, Ju, Mt, PH, PlH, Ply, PNB, Ta, ZR)

Silva-Benavides, A. M. 2009. Mangroves. In I. S. Wehrtmann \& J. Cortés (Eds.), Marine Biodiversity of Costa Rica, Central America (Texto: pp. 123-130, Lista de especies: Disco Compacto pp. 73-78). Berlin: Springer. $(\mathrm{Cp}, \mathrm{Mg}, \mathrm{PaN})$

Skoglund, C. (1990). Panamic Province molluscan range extensions from Bahía Cocos, Costa Rica. The Festivus, 22, 100 p. (Bd, Mgr, MoB, MoG, PdC, IV)
Skoglund, C. (1997). New Panamic Province distribution records for thirteen chiton (Polyplacophora) species. The Festivus, 29: 69-74. (Bd, Bg, Mgr, MoP, PdC)

Skoglund, C. (2001.) Panamic Province Molluscan Literature. Additions and changes from 1971 through 2000. I. Bivalvia. The Festivus, 32 (Supplement), 119 p. (BC, Bd, Bl, BSE, IT, Mgr, MoB, PdC)

Skoglund, C. (2001). Panamic Province Molluscan Literature. Additions and changes from 1971 through 2000. II Polyplacophora. The Festivus, 32 (Supplement), 20 p. (Bd, BU, IT, Mgr, MoP, PdC)

Skoglund, C. (2002). Panamic Province Molluscan Literature. Additions and changes from 1971 through 2001. III Gastropoda. The Festivus, 33 (Supplement), 286 p. (Bd, Bg, Bl, BSE, Mgr, MoG, Na, PdC, Tr)

Skoglund, C. \& Koch, R. (1995). New distribution information for Panamic Province Rissooidea (Mollusca, Gastropoda). The Festivus, 27: 23-28. (AC, BC, Bg, MoG, PdC, Tr)

Solano, G., Rojas-Jiménez, K., Jaspars, M. \& TamayoCastillo, G. (2009). Study of the diversity of culturable actinomycetes in the North Pacific and Caribbean coasts of Costa Rica. Antonie van Leeuwenhoek, 96, 71-78. (AC, At, Bd, CB, Mi, PNB)

Solano-Ugalde, A. (2006). Notas sobre la época reproductiva y caracteres juveniles de Vireo pallens (Vireonidae: Aves), Refugio de Vida Silvestre Curú, Puntarenas, Costa Rica. Brenesia, 66, 89-90. (AC, Av, Eg, Cu, Mg)

Solís-Marín, F. A., Arriaga-Ochoa, J. A., Laguarda-Figueras, A., Frontana-Uribe, S. C. \& Durán-González, A. (2009). Holoturoideos (Echinodermata: Holothuroidea) del Golfo de California. México DF: CONABIO, ICMyL, UNAM. 177 p. (BC, Bd, EcH, IT, Li)

Solís-Rivera, V., Fonseca-Borrás, M. \& Barguil-Gallardo, D. (2012). Conservación marina en el Parque Nacional Santa Rosa. Las comunidades de Cuajiniquil, La Cruz y El Jobo. In D. Barguil-Gallardo, V. SolísRivera \& M. Fonseca-Borrás (Eds.), Monografia: Estudio regional sobre las dimensiones sociales en el Manejo de Áreas Marinas Protegidas: Casos Costa Rica, Nicaragua, Honduras y Panamá. Chennai, India: International Collectives in Support of Fishworkers. (BEJ, Cj, LC, Ma, Mgr, PSR)

Soot-Ryen, T. (1955). A report on the Family Mytilidae (Pelecypoda). Allan Hancock Pacific Expeditions, 20, 1-175. (AC, BC, Bd, BS, BSE, MoB, PB, PdC)

Soto, R. (1988). Geometry, biomass allocation and leaf demography of Avicennia germinans (L.) L. (Avicenniaceae) along a salinity gradient in Salinas, Puntarenas, Costa Rica. Revista de Biología Tropical, 36, 309-323. (AC, Eg, BS, Mg)

Soto, R. (1992). Nutrient concentration and retranslocation in coastal vegetation and mangroves from the Pacific 
coast of Costa Rica. Brenesia, 37, 33-50. (AC, Eg, $\mathrm{BS}, \mathrm{Mg})$

Soto, R. \& Corrales, L. F. (1987). Variaciones de algunas características foliares de Avicennia germinans (L.) L. en un gradiente climático y de salinidad. Revista de Biología Tropical, 35, 245-256. (AC, Eg, BS, Mg)

Soto, R. \& Jiménez, J. (1982). Análisis fisonómico estructural del manglar de Puerto Soley, La Cruz, Guanacaste, Costa Rica. Revista de Biología Tropical, 30, 161-168. (AC, Eg, BS, Mg)

Sowerby, G. B. (1832). Characters of new species of Mollusca and Conchifera, collected by Hugh Cuming. Proceedings of the Zoological Society of London, Part II, 1832, 25-33 (February 28). (AC, Bd, BP, MoG)

Sowerby, G. B. (1832). Characters of new species of Mollusca and Conchifera, collected by Hugh Cuming. Proceedings of the Zoological Society of London, Part II, 1832, 50-61 (June 5). (AC, Bd, BP, MoG)

Sowerby, G. B. (1832). Characters of new species of Mollusca and Conchifera, collected by Hugh Cuming. Proceedings of the Zoological Society of London, Part II, 1832, 113-120 (June 12). (AC, Bd, $\mathrm{BP}, \mathrm{MoG})$

Spight, T. M. (1976). Censuses of rocky shore prosobranchs from Washington and Costa Rica. The Veliger, 18, 309-317. (AC, Bd, Eg, MoG, PdC, ZR)

Spight, T. M. (1977). Diversity of shallow-water gastropod communities on temperate and tropical beaches. The American Naturalist, 111, 1077-1097. (AC, Bd, Eg, MoG, PdC)

Spongberg, A. L. (2004). PCB contamination in surface sediments in the coastal waters of Costa Rica. Revista de Biología Tropical, 52 (Suplemento 2), 1-10. (AC, $\mathrm{BC}, \mathrm{CtC}, \mathrm{Sd})$

Spongberg, A. L. 2006. PCB concentrations in intertidal sipunculan (Phylum Sipuncula) marine worms from the Pacific coast of Costa Rica. Revista de Biología Tropical, 54 (Suplemento 1), 27-33. (AC, BC, $\mathrm{CtC}, \mathrm{Si}$ )

Spotilla, J. R. \& Paladino, F. V. (2004). Conservation lessons from a new national park and from 45 years of conservation of sea turtles in Costa Rica. In G. W. Frankie, A. Mata \& S. B. Vinson (Eds.), Biodiversity Conservation in Costa Rica. Learning the Lessons in a Seasonal Dry Forest (pp. 194-209). Berkeley, California: University of California Press. (Cp, Cv, PNB, TM)

Spotila, J. R., Standora, F., Morreale, S. \& Ruiz, G. (1987). Temperature dependent sex determination in the green turtle (Chelonia mydas): effects on the sex ratio on a natural nesting beach. Herpetologica, 43, 74-81. (AC, Eg, PG, TM)

Spotila, J. R., Reina, R. D., Steyermark, A. C., Plotkin, P. T. \& Paladino, F. V. (2000). Pacific leatherback turtles face extinction. Nature, 405, 529-530. (AC, Cv Eg, PG, TM)

Stapput, K. \& Wiltschko, W. (2005). The sea-finding behavior of hatchling olive ridley sea turtles, Lepidochelys olivacea, at the beach of San Miguel (Costa Rica). Naturwissenschaften, 92, 250-253. (AC, Eg, PSM, TM)

Steyermark, A. C., Williams, K., Spotila, J. R., Paladino, F. V., Rostal, D. C., Morreale, S. J., Kobert, M. T. \& Arauz, R. (1996). Nesting leatherback turtles at Las Baulas National Park, Costa Rica. Chelonian Conservation and Biology, 2, 173-183. (AC, Eg, PNB, TM)

Strong, A. M. \& Hertlein, L. G. (1937). The Templeton Crocker Expedition of the California Academy of Sciences, 1932. No. 35: New species of Recent mollusks from the coast of western North America. Proceedings of the California Academy of Sciences, 4th Series, 22, 159-178. (AC, Bd, IM, MoG)

Stukel, M. R., Décima, M., Selph, K. E., Taniguchi, D. A. A. \& Landry, M. R. (2013). The role of Synechococcus in vertical flux in the Costa Rica upwelling dome. Progress in Oceanography, 112-113, 49-59. (AC, Ci, DCR, PiP, OF)

Suárez, M. E., Fernández, W. \& Hidalgo, H. (1987). An application of Palmer's Drough Index to a semi-arid tropical region. Revista Geofísica, 27, 13-33 (AC, CA, Gua)

Suárez-Morales, E. \& Morales-Ramírez, A. (2001). Nuevo registro de Acartia (Planktacartia) negligens (Copepoda, Calanoida) en el Pacífico Tropical Oriental. Revista de Biología Tropical, 49, 1286. (AC, Bd, $\mathrm{CrC}, \mathrm{IM})$

Suárez-Morales, E. \& Morales-Ramírez, A. (2003). A new species of Cymbasoma (Crustacea: Copepoda: Monstrilloida) from the Pacific coast of Costa Rica, Central America. Proceedings of the Biological Society of Washington, 116, 206-214. (AC, BC, Bd, CrC)

Sunagawa, S. (2005). Seasonal variation in symbiont densities and skeletal phosphorus concentrations in the eastern Pacific (Costa Rica) coral Pavona clavus. Tesis de Maestría, ISATEC, Universidad de Bremen. Bremen, Alemania. 66 p. (BC, CnA, Eg, Sy, Te)

Sunagawa, S., Cortés, J., Jiménez, C. \& Lara, R. (2008). Variation in cell densities and pigment concentrations of symbiotic dinoflagellates in the coral Pavona clavus in the eastern Pacific (Costa Rica) / Variación en la densidad de células y en las concentraciones de pigmentos de los dinoflagelados simbióticos del coral Pavona clavus en el Pacífico oriental (Costa Rica). Ciencias Marinas, 34, 113-123. (AC, BC, $\mathrm{CnA}, \mathrm{Eg}, \mathrm{Sy})$

Swimmer, Y, Arauz, R., McCracken, M., McNaughton, L., Ballestero, J., Musyl, M., Bigelow, K. \& Brill, R. (2006). Diving behavior and delayed mortality of olive ridley sea turtles Lepidochelys olivacea 
after their release from longline fishing gear. Marine Ecology Progress Series, 323, 253-261. (AC, Cv, GP, $\mathrm{Pe}, \mathrm{TM})$

Swimmer, Y., McNaughton, L., Foley, D., Moxey, L. \& Nielsen, A. (2009). Movements of olive ridley sea turtles Lepidochelys olivacea and associated oceanographic features as determined by improved lightbased geolocation. Endangered Species Research, 10, 245-254. (AC, Eg, GP, OF, TM)

Swimmer, Y., Arauz, R., Wang, J., Suter, J., Musyl, M., Bolaños, A. \& López, A. (2010). Comparing the effects of offset and non-offset circle hooks on catch rates of fish and sea turtles in a shallow longline fishery. Aquatic Conservation: Marine and Freshwater Ecosystems, 20, 445-451. (AC, Cv, GP, Pe, TM)

Swimmer, Y., Suter, J., Arauz, R., Bigelow, K., López, A., Zanela, I., Bolaños, A., Ballestero, J., Suárez, R., Wang, J. \& Boggs, C. (2011). Sustainable fishing gear: the case of modified circle hooks in a Costa Rican longline fishery. Marine Biology, 158, 757767. (AC, Cv, GP, Pe)

Tarrant, A.M., Cortés, J., Atkinson, M., Atkinson, S., Johanning, K., Chiang, T.-c., Vargas, J. A. \& McLachlan, J. A. (2008). Three orphan nuclear receptors in the scleractinian coral Pocillopora damicornis from the Pacific coast of Costa Rica. Revista de Biología Tropical, 56 (Suplemento 4), 39-48. (AC, $\mathrm{BC}, \mathrm{CnA}, \mathrm{Gn}$ )

Tattersall, O. S. (1967). A survey of the genus Heteromysis (Crustacea: Mysidacea) with description of five new species from the tropical coastal waters of the Pacific and Indian Ocean with a key for the identification of the known species of the genus. Transactions of the Zoological Society of London, 31, 157-193. (AC, Bd, $\mathrm{BS}, \mathrm{CrD})$

Taylor, E. H. (1953). Early records of the seasnake Pelamis platurus in Latin America. Copeia, 1953(2), 124. (AC, $\mathrm{BC}, \mathrm{Bd}, \mathrm{Rp})$

Taylor, W. R. (1945). Pacific marine algae of the Allan Hancock Pacific Expeditions to the Galapagos Islands. Allan Hancock Pacific Expeditions, 12, 1-528. (AC, Al, BC, Bd, BS)

Tokioka, T. (1971). A new species of Rhopalaea from the Pacific coast of Costa Rica (Tunicata, Ascidiacea). Publication of the Seto Marine Biological Laboratory, 19(2/3), 119-122. (AC, Bd, PdC, Tn)

Tokioka, T. (1972). On a small collection of ascidians from the Pacific coast of Costa Rica. Publication of the Seto Marine Biological Laboratory, 19(6), 383-408. (AC, $\mathrm{Bd}, \mathrm{PdC}, \mathrm{Tn})$

Tovar-Hernández, M. A. \& Carrera-Parra, L. F. (2011). Megalomma Johansson, 1925 (Polychaeta: Sabellidae) from America and other world-wide localities, and phylogenetic relationships within the genus. Zootaxa, 2861, 1-71. (AC, BC, Bd, BS, Py)
Tsuda, R. T. (1968). Additional records of marine benthic algae from Costa Rica. Caribbean Journal of Science, 8, 103-104. (AC, Al, Bd, PdC)

Tu, A. T. (1976). Investigation of the sea snake, Pelamis platurus (Reptilia, Serpentes, Hydrophiidae), on the Pacific coast of Costa Rica, Central America. Journal of Herpetology, 10, 13-18. (AC, BC, Eg, Rp)

Türkay, M. (1970). Die Gecarcinidae Amerikas. Mit einem Anhang über Ucides Rathbun. Senckenbergiana biologica, 51, 333-354. (AC, BC, Bd, CrD)

Umatani, S. \& Yamagata, T. (1991). Response of the eastern tropical Pacific to meridional migration of the ITCZ: The generation of the Costa Rica Dome. Journal of Physical Oceanography, 21, 346-363. (AC, CA, DCR, GP, OF)

Valdés, A. \& Barwick, K. (2005). First record of Akera Müller, 1776, from the eastern Pacific, with the description of a new species. The Nautilus, 119, 43-49. (AC, Bd, BS, MoG)

Valdés, Á. \& Camacho-García, Y. (2000). A new species of Cyerce Bergh, 1871 (Mollusca, Sacoglossa, Polybranchiidae) from the Pacific coast of Costa Rica. Bulletin of Marine Science, 66, 445-456. (AC, Bd, CB, Cy, $\mathrm{MoG})$

Valdés, Á. \& Camacho-García, Y. E. (2004). "Cephalaspidean" Heterobranchs (Gastropoda) from the Pacific Coast of Costa Rica. Proceedings of the California Academy of Sciences, 55, 459-497. (AC, BC, Bd, BEJ, $\mathrm{BU}, \mathrm{Bm}, \mathrm{BP}, \mathrm{BS}, \mathrm{BSE}, \mathrm{BSJ}, \mathrm{Bt}, \mathrm{CB}, \mathrm{Cj}, \mathrm{FPG}, \mathrm{GP}$, IM, IP, IT, Ju, MoG, Mt, Na, PB, PCt, PD, PdC, PG, $\mathrm{Pj}, \mathrm{Po}, \mathrm{PZ})$

Valdez, M. F. \& Villalobos, C. R. (1982). Variations in natural populations of Neritina latissima Broderip (Gastropoda: Neritidae) in Costa Rica. Anales del Instituto de Ciencias del Mar y Limnología, Universidad Nacional Autónoma de México, 9, 111-119. (AC, Eg, $\mathrm{MoG}, \mathrm{Mz})$

Valverde, R. A. \& Gates, C. E. (1999). Population surveys on mass nesting beaches. In K. L. Eckert, K. A. Bjorndal \& F. A. Abreu-Grobois, (eds.). Research and Management Techniques for the Conservation of Sea Turtles. IUCN/SSC Marine Turtle Specialist Group Publication No. 4, Washington, DC, p 56-60 (Arb, Cp, Eg, Na, TM)

Valverde, R. A., Cornelius, S. E. \& Mo, C. L. (1998). Decline of the olive ridley sea turtle (Lepidochelys olivacea) nesting assemblage at Nancite beach, Santa Rosa National Park, Costa Rica. Chelonian Conservation and Biology, 3, 58-63. (AC, Arb, Eg, Na, TM)

Valverde, R. A., Owens, D.W., Mackenzie, D. S. \& Amoss, M. S. (1999) Basal and stress-induced corticosterone levels in olive ridley sea turtles (Lepidochelys olivacea) in relation to their mass nesting behavior. Journal of Experimental Zoology, 284, 652-662. (AC, Arb, Eg, Na, TM) 
Valverde, R. A., Selcer, K. W., Lara, L. R. \& Sibaja-Cordero, J. A. (2008). Lack of xenoestrogen-induced vitellogenin in male olive ridley sea turtles (Lepidochelys olivacea) from the Pacific coast of Costa Rica. Revista de Biología Tropical, 56 (Suplemento 4), 49-57. (AC, $\mathrm{Eg}, \mathrm{Os}, \mathrm{TM})$

Valverde, R. A., Wingard, S., Gómez, F., Tordoir, M. T. \& Orrego, C. M. (2010) Field lethal incubation temperature of olive ridley sea turtle Lepidochelys olivacea embryos at a mass nesting rookery. Endangered Species Research, 12, 77-86. (AC, Arb, Eg, Os, TM)

Valverde, R. A, Orrego, C. M., Tordoir, M. T., Gómez, F. M., Solís, D. S., Hernández, R. A., Gómez, G. B., Brenes, L. S., Baltodano, J. P., Fonseca, L. G., Spotila, J. R. (2012) Olive Ridley mass nesting ecology and egg harvest at Ostional Beach, Costa Rica. Chelonian Conservation and Biology, 11, 1-11. (AC, Eg, Ma, Os, TM)

Van Cleave, H. J. (1940). The Acanthocephala collected by the Allan Hancock Pacific Expedition, 1934. Allan Hancock Pacific Expeditions, 2(15), 501-527. (AC, $\mathrm{BC}, \mathrm{Bd}, \mathrm{PpA})$

Vargas, J. M. (2002). Interacción océano-atmósfera: surgencia y generación de anillos en la región de Papagayo. Revista de Geografia de América Central, 40, 133144. (AC, CA, GP, OF)

Vargas, R. (2000). Periclimenes murcielagensis, a new species of shrimp (Crustacea: Decapoda: Palaemonidae) living on black coral from the Pacific coast of Costa Rica. Proceedings of the Biological Society of Washington, 113, 17-23. (AC, Bd, CnA, CrD, IM)

Vargas-Castillo, R. (2008). Estomatópodos y decápodos (Crustacea), de la expedición RV Urracá-STRI (2005) en las costas del Pacífico central y norte de Costa Rica. Revista de Biología Tropical, 56 (Suplemento 4), 105-112. (AC, Bd, CrD, CRS, GP)

Vargas-Castillo, R. (2012). Nuevas adiciones a la fauna de crustáceos decápodos de Bahía Culebra, Guanacaste, Costa Rica. Revista de Biología Tropical, 60 (Suplemento 2), 73-76. (AC, BC, Bd, CrD)

Vargas, R. \& Cortés, J. (1997). Biodiversidad marina de Costa Rica: Orden Stomatopoda (Crustacea: Hoplocarida). Revista de Biología Tropical, 45, 1531-1539. (AC, BC, Bd, Bl, BS, BSE, Cl, Cr, CrS, Oc, PB, PCh, $\mathrm{PdC}, \mathrm{Tr})$

Vargas, R. \& Cortés, J. (1999). Biodiversidad marina de Costa Rica: Crustacea. Decapoda (Penaeoidea, Sergestoidea, Caridea, Astacidea, Thalassinidea, Palinura) del Pacífico. Revista de Biología Tropical, 47, 887911. (AC, BC, Bd, BSE, CB, CrD, IM, JuN, PB, PdC, PSR, Tr)

Vargas, R. \& Cortés, J. (2006). Biodiversidad marina de Costa Rica: Crustacea: Infraorden Anomura. Revista de Biología Tropical, 54, 461-488. (AC, BC, Bd, Bi,
BS, BSE, Bt, CB, CrD, IM, Ju, No, Os, PB, PCh, PdC, $\mathrm{Pj}, \mathrm{Pty}, \mathrm{Sr}, \mathrm{Tr}$ )

Vargas-Montero, M. (2004). Floraciones algales en Costa Rica y su relación con algunos factores meteorológicos y consideraciones sobre sus efectos socioeconómicos. Tesis de Maestría, GIACT, Universidad de Costa Rica. San Pedro, Costa Rica. 90 p. (BC, CA, FAN, SE, Te)

Vélez, R. E., Dutton, P., Possardt, E. \& Padilla, C. (2007). Nesting of the Leatherback Turtle (Dermochelys coriacea) from 1999-2000 through 2003-2004 at Playa Langosta, Parque Nacional Marino Las Baulas de Guanacaste, Costa Rica. Chelonian Conservation and Biology, 6, 111-116. (AC, Eg, PNB, TM)

Vilchis, L. I., Ballance, L. T. \& Watson, W. (2009). Temporal variability of neustonic ichthyoplankton assemblages of the eastern Pacific warm pool: Can community structure be linked to climate variability? Deep-Sea Research I, 56, 125-140. (AC, CA, FCG, Ip)

Villalobos, C. R. (1980). Variations in population structure in the genus Tetraclita (Crustacea: Cirripedia) between temperate and tropical populations. III. Fecundity, recruitment, mortality and growth in $T$. stalactifera. Revista de Biología Tropical, 28, 193201. (AC, Bl, CrP, Eg, Ta)

Villalobos, C. R. (1980). Variations in population structure in the genus Tetraclita (Crustacea: Cirripedia) between temperate and tropical populations. IV. The age structure of $T$. stalactifera, and concluding remarks. Revista de Biología Tropical, 28, 353-359. (AC, B1, CrP, Eg, Ta)

Villalobos, C. R. (1980). Algunas consideraciones sobre el efecto de los factores físicos y biológicos en la estructura de una comunidad de algas en el Pacífico de Costa Rica. Brenesia, 18, 289-300. (AC, Al, Eg, Mz)

Villalobos, C. R., Cruz, G. A. \& Cruz, R. A. (1985). Notas sobre la biología de Sphaeroma terebrans Bate 1966 (Sphaeromatidae, Isopoda) en el manglar de Pochote, Provincia de Puntarenas, Costa Rica. Brenesia, 24, 287-296. (AC, Bl, CrI, Eg, Mg, Pt)

Villalobos-Rojas, F. \& Wehrtmann, I.S. (2011). Gonad development in the commercially exploited deepwater shrimp Solenocera agassizii (Decapada: Solenoceridae) from Pacific Costa Rica, Central America. Fisheries Research, 109, 150-156. (AC, CrD, Eg, $\mathrm{GP}, \mathrm{Pe}$ )

Villalobos-Rojas, F., Guzmán-Mora, A. G. \& CamachoGarcía, Y. E. (2008). Catalogue of the type material of mollusks deposited at the Zoology Museum, University of Costa Rica. The Nautilus, 122, 155-165. (Bd, $\mathrm{CB}, \mathrm{Cj}, \mathrm{Co}, \mathrm{Ju}, \mathrm{MoB}, \mathrm{MoG}, \mathrm{PAv}, \mathrm{PdC}, \mathrm{Tr})$

Villalobos-Rojas, F., Herrera-Correal, J., Garita-Alvarado, C. A., Clarke T. \& Beita-Jiménez, A. (2014). Pesquerías del Pacifico Norte costarricense: características y 
recomendaciones para un manejo sostenible. Revista de Biología Tropical, 62 (Suplemento 4), 119-138. (AC, Cby, Cj, Ma, Ml, Mz, Oc, PCy, PdC, Pe)

Wallace, B. P. \& Piedra-Chacón, R. (2012). Leatherbacks in the balance. In J. A. Seminoff \& B. P. Wallace (Eds.), Sea Turtles of the Eastern Pacific: Advances in Research and Conservation. (pp. 193-223). Tucson: The University of Arizona Press. (Cp, Cv, PNB, TM)

Wallace, B. P., Williams, C. L., Paladino, F. V., Morreale, S. J., Lindstrom, R. T. \& Spotila, J. R. 2005. Bioenergetics and diving activity of internesting leatherback turtles Dermochelys coriacea at Parque Nacional Marino Las Baulas, Costa Rica. The Journal of Experimental Biology, 208, 3873-3884. (AC, Eg, Fs, PG, TM)

Wallace, B. P., Seminoff, J. A., Kilham, S. S., Spotila, J. R. \& Dutton, P. H. (2006). Leatherback turtles as oceanographic indicators: stable isotope analyses reveal a trophic dichotomy between ocean basins. Marine Biology, 149, 953-960. (AC, Eg, Ist, PG, TM)

Warén, A. (1992). Comments on and descriptions of eulimid gastropods from tropical west America. The Veliger, 35, 177-194. (AC, Bd, B1, BP, IT, MoG)

Wehrtmann, I. S. \& Nielsen-Muñoz, V. (2009). The deepwater fishery along the Pacific coast of Costa Rica, Central America. Latin American Journal of Aquatic Research, 37, 543-554. (AC, CrD, FCG, Pe, ZP)

Wehrtmann, I. S. \& Vargas, R. (2003). New records and range extensions of shrimps (Decapoda: Penaeoidea, Caridea) from the Pacific and Caribbean coasts of Costa Rica, Central America. Revista de Biología Tropical, 51, 268-274. (AC, BC, Bd, Bg, CrD, IM, Oc)

Wehrtmann, I. S., Herrera-Correal, J., Vargas, R. \& Hernáez, P. (2010). Squat lobsters (Decapoda: Anomura: Galatheidae) from deepwater Pacific Costa Rica: species diversity, spatial and bathymetric distribution. The Nauplius, 18, 69-77. (AC, Bd, Bg, CrD, FCG, GP, ZP)

Whoriskey, S., Arauz, R. \& Baum, J. K. (2011). Potential impacts of emerging mahi-mahi fisheries on sea turtle and elasmobranch bycatch species. Biological Conservation, 144, 1841-1849. (AC, FCG, Pe, PiA, PiE, TM)

Wibbels, T., Rostal, D. C. \& Byles, R. (1998). High pivotal temperature in the sex determination of the olive ridley sea turtle, Lepidochelys olivacea, from Playa Nancite, Costa Rica. Copeia, 1998, 1086-1088. (AC, $\mathrm{Eg}, \mathrm{Na}, \mathrm{TM})$
Wicksten, M. K. (1979). New records of the species of Glyphocrangon in the northeastern Pacific Ocean (Caridea: Glyphocrangonidae). Proceedings of the Biological Society of Washington, 92, 217-224. (AC, $\mathrm{Bd}, \mathrm{CrD}, \mathrm{FPG})$

Wicksten, M. K. (1982). Pinnixa costaricana, a new species of crab from Central America (Brachyura: Pinnotheridae). Proceedings of the Biological Society of Washington, 95, 579-582. (AC, Bd, CrD, $\mathrm{PdC}$ )

Wicksten, M. K. (1983). Shallow water caridean shrimps of the Gulf of California, México. Allan Hancock Monographs on Marine Biology, 13, 1-59. (BC, Bd, BSE, CrD, Mgr, PB)

Wicksten, M. K. \& Hendrickx, M. E. (1992). Checklist of Penaeoid and Caridean shrimps (Decapoda: Penaeoidea, Caridea) from the eastern tropical Pacific. Proceedings of the San Diego Society of Natural History, 9, 1-11. (AC, Bd, CB, CrD)

Wicksten, M. K. \& Hendrickx, M. E. (1992). An updated checklist of benthic marine and brackish water shrimps (Decapoda: Penaeoidea, Stenopodidea, Caridea) from the Eastern Tropical Pacific. In M. E. Hendrickx (Ed.), Contributions to the Study of East Pacific Crustaceans, 2. [Contribuciones al estudio de los Crustáceos del Pacífico Este, 2] (pp. 49-76). México DF: Instituto de Ciencias del Mar y Limnología, UNAM. (BC, Bd, BS, BSE, Cp, CrD, FCB, IM, IP, IV, PB, PdC, Tr)

Williams, A. B. (1986). Mud shrimps, Upogebia, from the eastern Pacific (Thalassinoidea: Upogebiidae). San Diego Society of Natural History Memoir, 14, 1-60. (Bd, BP, CrD, Mgr)

Williams, A. B. (1997). Two new species and a range extension of mud shrimps, Upogebia, from Pacific Costa Rica and Mexico (Decapoda: Thalassinidea: Upogebiidae). Proceedings of the Biological Society of Washington, 110, 617-623. (AC, Bd, CrD, Pty)

Williams, A. B. \& Vargas, R. (2000). A new species of mud shrimp, Upogebia cortesi, from Pacific Costa Rica (Decapoda: Thalassinidea: Upogebiidae). Proceedings of the Biological Society of Washington, 113, 13-16. (AC, Bd, CB, CrD)

Wilson, C. B. (1937). Parasitic copepods taken during the third Hancock expedition to the Galapagos Islands. Allan Hancock Pacific Expeditions, 2(4), 23-31. (AC, BC, Bd, PiA, PpC)

Witteveen, B. H., Worthy, G. A. J., Wynne, K. \& Roth, J. D. (2009). Population structure of North Pacific humpback whales on feeding grounds as shown by stable carbon and nitrogen isotope ratios. Marine Ecology Progress Series, 379, 299-310. (AC, CB, Eg, Ist, $\mathrm{MM}, \mathrm{PaN}$ ) 
Witteveen, B. H., Worthy, G. A. J. \& Roth, J. D. (2009). Tracing migratory movements of breeding North Pacific humpback whales using stable isotope analysis. Marine Ecology Progress Series, 393, 173-183. (AC, CB, Eg, Ist, MM, PaN)

Xie, S.- P., Xu, H., Kessler, W. S. \& Nonaka, M. (2005) Air-Sea interaction over the Eastern Pacific Warm Pool: Gap winds, thermocline dome, and atmospheric convection. Journal of Climate, 18, 5-20. (AC, CA, DCR, FCG, OF)

Young, B. E., Easley, K., Garrigues, R., Mactavish, B. Murgatroyd, P. \& Zook, J. R. (2010). Swallow-tailed Gull Creagrus furcatus in Costa Rica. Cotinga, 32, 24-26. (AC, Av, Bg, GP)

Zamora, H. (1924). Sardinal, Golfo de Culebra y Bahía de Coco. Revista de Costa Rica, Año V, Número 8, 200201. (AC, BC, Hi, PdC)

Zamora-Trejos, P. \& Cortés, J. (2009). Los manglares de Costa Rica: Pacífico norte. Revista de Biología Tropical, 57, 473-488. (AC, BC, Eg, BS, BSE, Mg, PSR, TR)

Ziesenhenne, F. C. (1940). New ophiurans of the Allan Hancock Pacific Expeditions. Allan Hancock Pacific Expeditions, 8, 9-59. (AC, BC, Bd, BS, EcO)

\section{Otros trabajos citados:}

Barraza, E. (2014). Invertebrados marinos de El Salvador. San salvador, El Salvador: Ministerio de Medio Ambiente y Recursos Naturales. 96 p.

Cortés, J. (Editor) (2012d). Investigaciones marinas en el Parque Nacional Isla del Coco, Costa Rica / Marine Research at Isla del Coco National Park, Costa Rica. Revista de Biología Tropical, Volumen 60, Suplemento 3, $394 \mathrm{p}$.

MARN (Ministerio de Ambiente y Recursos Naturales) (2011). Biodiversidad marino costera de El Salvador: Análisis de vacíos y estrategia para su conservación. The Nature Conservancy (TNC), Programa de Gautema, Región Latinoamérica. 120 p.

Quesada-Alpízar, M. A. \& Cortés, J. (2006). Los ecosistemas marinos del Pacífico sur de Costa Rica: estado del conocimiento y perspectivas del manejo. Revista de Biología Tropical, 54 (Suplemento 1), 101-145.

Vargas, J. A. \& Mata, A. 2004. Where the dry forest feeds the sea: the Gulf of Nicoya Estuary. In G. W. Frankie, A. Mata \& S. B. Vinson (Eds.). Biodiversity Conservation in Costa Rica: Learning the Lessons in a Seasonal Dry Forest (pp 126-135). Berkeley, Los Angeles, London: University of California Press. 